\title{
The impact of forest disturbance on the fine root system of a tropical forest on Sulawesi, Indonesia
}

\author{
Dissertation \\ zur Erlangung des Doktorgrades \\ der Mathematisch-Naturwissenschaftlichen Fakultäten \\ der Georg-August-Universität zu Göttingen
}

vorgelegt von

Marieke Aaltje Harteveld

aus Amersfoort

Göttingen, im März 2007 
D 7

Referent: Prof. Dr. Christoph Leuschner

Korreferent: PD Dr. Michael Kessler

Tag der mündlichen Prüfung: 


\begin{abstract}
Selective logging and forest conversion into agroforestry systems are widespread at the margins of tropical moist forests in South-east Asia, typically creating gradients of forest disturbance intensity from the edge to the interior. These disturbances alter the structure of the forest ecosystem and consequently its carbon budget. To predict the impact of forest conversion in the tropics on the below ground carbon cycle, an improved understanding of the response of the fine root system to disturbance is needed. In a gradient study, we investigated the effect of increasing forest use intensity on fine root bio- and necromass, fine root growth and fine root morphology of a tropical moist forest in Central Sulawesi, Indonesia.

Increasing intensity of forest use led to a significant decrease in fine root biomass and necromass. Even the extraction of only a limited number of small-diameter stems had a significant negative impact on the fine root biomass. Fine root production (growth in $\mathrm{g} \mathrm{m}^{-2}$ ) showed a weak dependence on forest disturbance, whereas fine root growth activity (growth per fine root biomass) was distinctly higher in the more heavily disturbed stands. The higher growth activity of fine roots in the moderately and heavily disturbed forests resulted from differences in fine root morphology and fine root $\mathrm{N}$ content. This higher growth activity partly compensated for the decrease in fine root biomass with disturbance. Never the less, the amount of carbon annually added to the soil carbon stock through fine root litter production was highest in the undisturbed forest and decreased with increasing forest use intensity. We conclude that forest encroachment, that is widespread in large parts of South-east Asia's remaining rainforests, significantly reduces tree fine root biomass and associated carbon sequestration, even if it is conducted at moderate intensities only.
\end{abstract}




\section{Zusammenfassung}

Selektiver Holzeinschlag und die Konvertierung von Wald in Waldfeldbausysteme sind an den Regenwaldrändern in Süd-Ost-Asien weit verbreitet. Diese Störung des Waldes führt zu einer nachhaltigen Veränderung der Bestandsstruktur und damit zu veränderten Ökosystemprozessen, einschließlich des Kohlenstoffkreislaufs. Bei der Abschätzung des Waldumbaus auf den unterirdischen Kohlenstoffkreislauf kommt dem Feinwurzelsystem eine bedeutende Rolle zu. Dazu untersuchten wir den Einfluss zunehmender Waldstörung entlang eines Landnutzungsgradienten auf die Bio- und Nekromasse, das Wachstum und die Morphologie von Feinwurzeln in einem tropischen Regenwald auf Sulawesi, Indonesien. Die zunehmende Waldstörungsintensität führte zu einer signifikanten Abnahme von sowohl Bio- als auch Nekromasse, wobei schon die Entnahme weniger Bäume mit einem geringen Durchmesser einen negativen Effekt auf die Feinwurzelbiomasse hatte. Die Feinwurzelproduktion wurde durch die zunehmende Störungsintensität nur in geringen Maßen beeinflusst. Die Wachstumsrate, das Verhältnis Wachstum zu Biomasse, hingegen war auf den Beständen mittlerer und schwerer Störungsintensität merklich höher, wodurch der Rückgang der Feinwurzelbiomasse auf diesen Flächen teilweise kompensiert wurde. Dieses war auf Unterschiede in der Feinwurzelmorphologie und des Stickstoffgehalt in den Feinwurzeln zurückzuführen. Die jährliche Zufuhr an Kohlenstoff zum gesamten Kohlenstoffvorrat im Boden durch abgestorbene Feinwurzelbiomasse war dennoch im ungestörten Naturwald am höchsten und nahm mit zunehmender Störungsintensität ab. Wir schließen daraus, dass eine negative Beeinträchtigung von tropischen Regenwäldern durch anthropogenen Einfluss, welche in Süd-Ost-Asien weit verbreitet ist, maßgeblich die Feinwurzelbiomasse von Bäumen und die damit assoziierte Kohlenstoffsequestration reduziert. 


\section{Table of contents}

Chapter 1

General introduction

Chapter 2

Patterns of fine root mass and distribution along a disturbance gradient in a tropical montane forest, Central Sulawesi (Indonesia)

Ch. Leuschner, M. Wiens, M. Harteveld, D. Hertel, S. Tjitrosemito

\section{Chapter 3}

Spatial and Temporal Variability of Fine Root Abundance and Growth in

Tropical Moist Forests and Agroforestry Systems (Sulawesi, Indonesia)

\section{Chapter 4}

Conversion of a tropical forest into agro-forest alters the fine root related carbon sink strength

\section{Chapter 5}

Consequences of increasing forest use intensity for the biomass, morphology and growth of fine roots in a tropical moist forest, Sulawesi, Indonesia

Chapter 6

Synthesis

Acknowledgements 


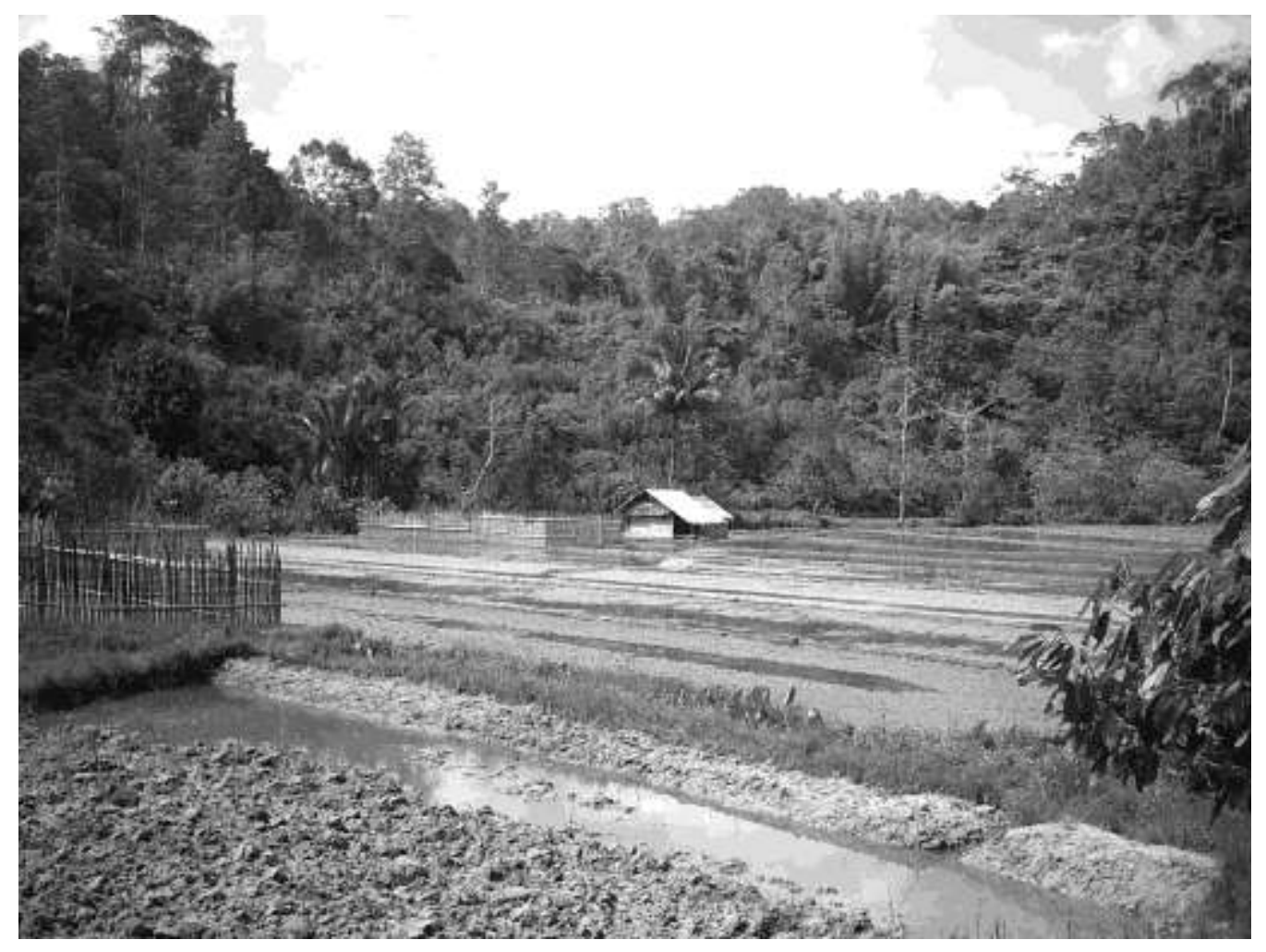


Chapter 1

General introduction 


\section{Tropical rainforests and the terrestrial carbon cycle}

The main carbon pools within the global carbon cycle are atmospheric $\mathrm{CO}_{2}$, biota (mostly vegetation), soil organic matter including detritus and the oceans (Fig.1 Janzen 2004). The largest terrestrial carbon pool, about $1500-2000 \mathrm{Gt} \mathrm{C}$ is contained within the soil in different organic forms, the atmosphere holds around $785 \mathrm{Gt}$ carbon in the form of $\mathrm{CO}_{2}$ and the $\mathrm{C}$ pool in biota is about 400-600 Gt (Fig. 1, IPCC 2000). These three carbon pools, that form the terrestrial carbon cycle, are interconnected: Annually, around $120 \mathrm{Gt}$ of atmospheric $\mathrm{CO}_{2}$ enters the terrestrial biomass via photosynthesis, about half of that gets quickly returned to the atmosphere by plant respiration, the other half (the net primary production, NPP) is at least temporarily stored in plant biomass, but most eventually enters the soil through mortality and decomposition. Simultaneously heterotrophic respiration, mainly by soil microorganisms, and fire return an amount of $\mathrm{C}$ to the atmosphere that roughly equals net primary production, thereby closing the cycle (Janzen 2004). The amount of atmospheric $\mathrm{CO}_{2}$ (the main greenhouse gas) is annually increasing due to the emission of 5.5 to $6.5 \mathrm{Gt} C$ per year from fossil fuels and industrial activity and an additional $1.6 \mathrm{Gt}$ per year from deforestation (IGBP 2001). Some of these emissions can be absorbed by terrestrial ecosystems and oceans. Nevertheless, an average of $3.4 \mathrm{Gt}$ of carbon is accumulated in the atmosphere each year. The terrestrial absorption is the small difference between the large amounts of carbon exchanged between terrestrial ecosystems and the atmosphere. Currently, this difference results in a net terrestrial sink of about 2 Gt per year (IGBP 2001).

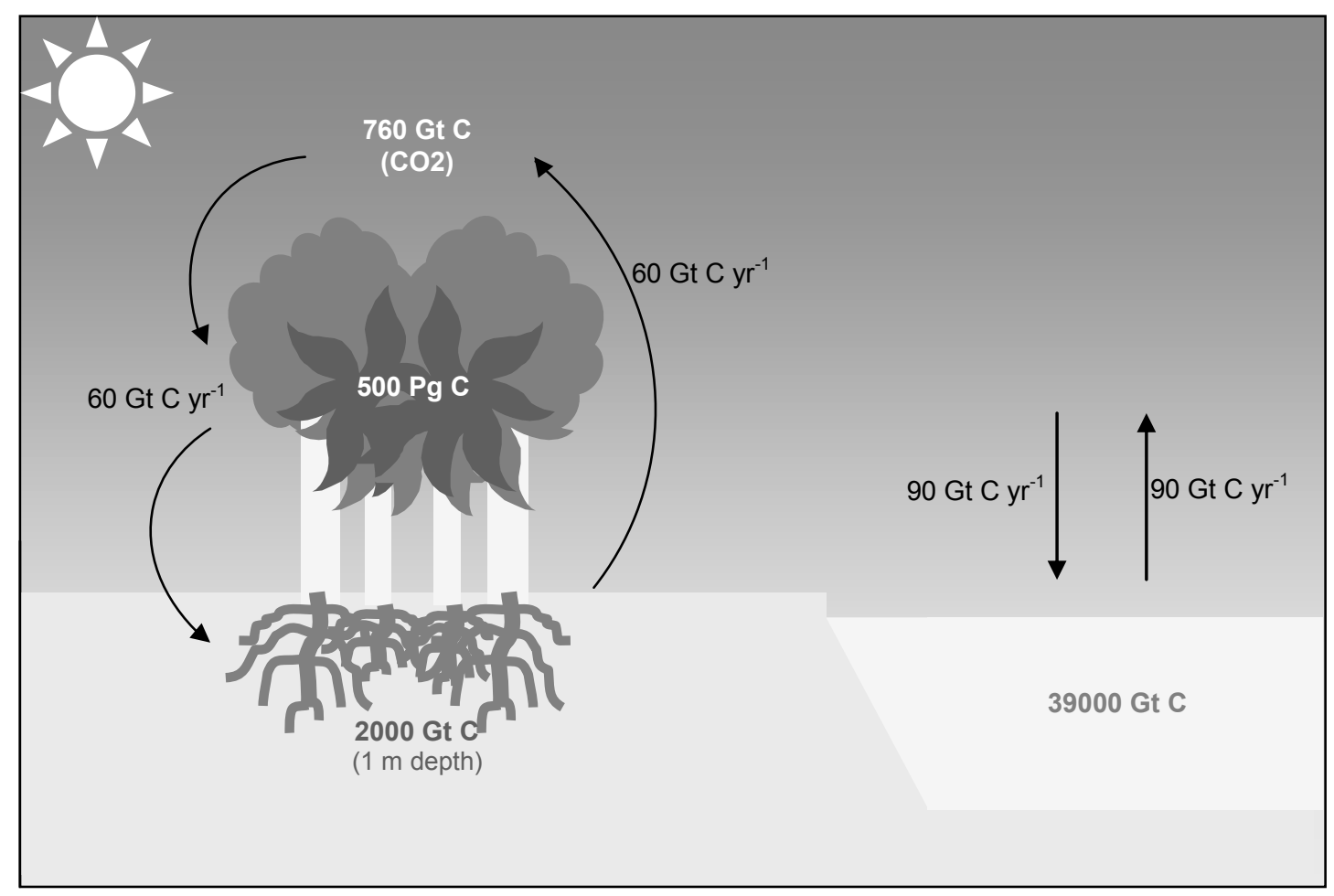

Fig.1 Overview of the global carbon cycle based on data from IPCC (2000). 
Globally, forests hold up to $75 \%$ of the total carbon stocks in biota (IPCC 2000) and even small shifts in the balance between photosynthesis and ecosystem respiration can result in a large change in the uptake or emission of $\mathrm{CO}_{2}$ from forests to the atmosphere (Pregitzer \& Euskirchen 2004). Tropical forests play a particularly important role in the terrestrial carbon budget as they contain more than $40 \%$ of the world's forest biomass (Dixon et al. 1994; FAO 2005) and soil carbon (Jobbágy \& Jackson 2000). During vegetation succession, forest ecosystems can accumulate carbon in four major pools: living vegetation, coarse woody debris, organic soil horizons and soil. Pools of total ecosystem $C$ in mature forests can be impressive, normally ranging from $100-200 \mathrm{Mg} \mathrm{ha}^{-1}$ and sometimes exceeding $500 \mathrm{Mg} \mathrm{ha}^{-1}$ (Janish \& Harmon 2002). The vast accumulation of biomass within mature, tropical rain forests might give the impression that these ecosystems continue to accumulate $\mathrm{C}$. Although this is true for individual trees within a forest, mature forests as a whole maintain a steady state with approximately equal rates of $C$ fixation and C release (van Noordwijk et al. 1997). At the biome level $\mathrm{C}$ stocks in organic soil horizons, that are primarily constituted by detritus from above and belowground plant parts, either remain constant or increase with age. The formation of mineral soil $\mathrm{C}$ with a relatively long residence time (stabile soil $\mathrm{C}$ ) is thought to be primarily controlled by three mechanisms: chemical stabilisation, physical protection and biochemical stabilization (Six et al. 2002). Disturbance history and the age class distribution of forests within a biome are very important in controlling rates of $\mathrm{C}$ cycling and storage.

\section{The role of fine roots in the forest carbon cycle}

Trees use a considerable amount of carbon for the production and maintenance of fine roots ( $<2 \mathrm{~mm}$ diameter), the organs that are responsible for the uptake of water and nutrients (Raich and Nadelhoffer 1989). Therefore, fine roots are a prominent sink for carbon acquired through canopy photosynthesis (Nadelhoffer \& Raich 1992; Hendrick \& Pregitzer 1992; Jackson et al. 1997). Although tree fine roots represent only a few percent of the total tree biomass, they can consume 30 to $50 \%$ of the annual primary production (Vogt et al. 1996; Ruess et al. 1996; Xiao et al. 2003). Fast growth and turnover of fine roots make the fine root system a dynamic component of the forest carbon cycle. The small diameter, relatively short lifespan, and low $\mathrm{C}: \mathrm{N}$ ratio of fine roots result in their rapid turnover, making them disproportionately important for estimates of annual net primary production, nutrient cycling, and carbon allocation (Jackson et al 1997). C transfer with root death may contribute more to soil carbon fluxes than $C$ transfer with above-ground litter fall (Silver et al. 2005). The importance of $C$ transfer with root death might be even greater considering the fact that root derived $\mathrm{C}$ generally has a longer residence time compared to shoot derived $\mathrm{C}$ (Rasse et al. 2005).

Despite the fact that $\mathrm{C}$ allocation to the root system is one of the most important $\mathrm{C}$ fluxes in terrestrial ecosystems, it remains poorly quantified (Hendrick \& Pregitzer 1992; Davidson et al. 2002; Matamala et al. 2003). However, Jackson et al. (1997) estimated that globally 
about 19.9 Gt of carbon is stored in living fine roots. About $30 \%$ of that is contained within tropical forests. High fine root biomass is a common feature in many tropical forests, generally occurring as root mats on the soil surface (Sanford \& Cuevas 1996). The average standing fine root biomass $(0-50 \mathrm{~cm}$ soil depth) in tropical moist forests around the globe is $451( \pm 45) \mathrm{g} \mathrm{m}^{-2}$ (Hertel and Leuschner, 2005). However, root biomass can differ largely between stands depending on tree species, soil conditions and profile depth analysed. From the limited number of existing studies, it appears that tropical montane forests have higher fine root biomass totals in the profile $(\mathrm{d}<2 \mathrm{~mm})$ than tropical lowland forests (Vogt et al. 1996, Cairns et al. 1997).

\section{Tropical deforestation}

Deforestation, mainly by conversion of forests to agricultural land, continues at an alarmingly high rate of about 13 million hectares per year (Nepstad et al. 1999; Achard et al. 2002; FAO 2005). However, forest planting, landscape restoration, and natural expansion of forests have significantly reduced the net loss of forest area. The net decline in forest area in the period 2000-2005 is estimated at 7.3 million hectares per year (equivalent to $200 \mathrm{~km}^{2}$ per day), down from 8.9 million hectares per year in the period 1990-2000 (FAO 2005).

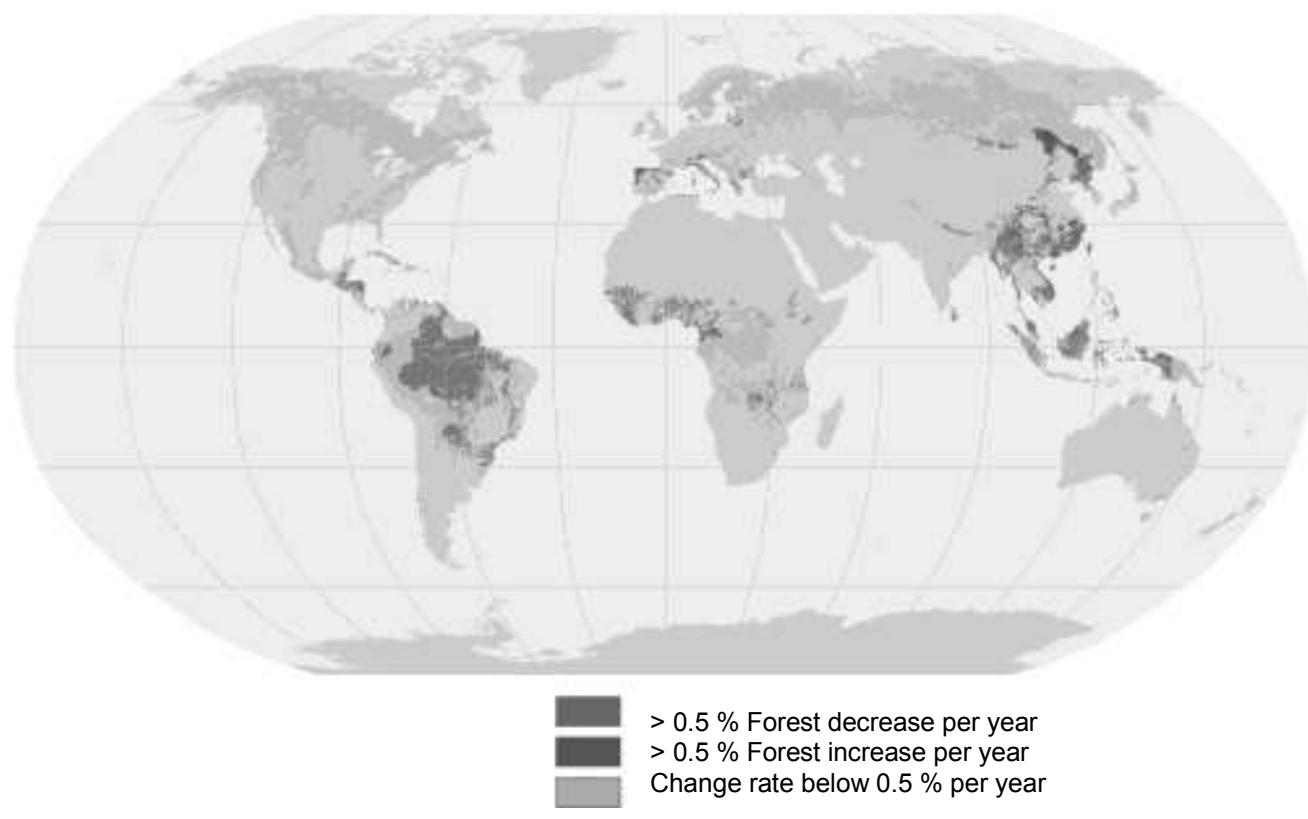

Fig. 2. Annual changes in forested area according to the FAO (2005).

The loss or modification of primary forests through deforestation or selective logging occurs at a rate of 6 million hectares per year. The ten countries that currently have the largest net forest loss per year are Brazil, Indonesia, Sudan, Myanmar, Zambia, United Republic of Tanzania, Nigeria, Democratic Republic of the Congo, Zimbabwe, and Venezuela. These countries had a combined net forest loss of 8.2 million hectares per year (FAO 2005). 
Overall forest degradation is highest in South-East Asia, compared to other tropical regions (Lambin et al. 2003).

\section{Forest conversion in Indonesia}

Indonesia holds a vital share of the world's remaining humid rainforests, as it represents around $10 \%$ of the world's rainforests and nearly $50 \%$ of all Asian rainforests (FAO 2005). However, at the same time the country suffers one of the highest rates of deforestation. Since 1950 over $40 \%$ of the forests in Indonesia have disappeared (FWI/GWI 2002). Indonesia's tropical lowland forests have suffered most. In Sulawesi and Sumatra they have almost completely been cleared and if current trends continue, tropical lowland forests will soon have disappeared on Kalimantan as well. Nearly half of Indonesia's forests are fragmented by roads, other access routes and plantations (FWI/GWI 2002). From the midsixties on, commercial exploitation of forests in the outer islands has increased rapidly, making Indonesia one of the world leaders in the export of tropical timber (Sunderlin \& Resosudarmo 1996). Large parts of Indonesia's forests are allocated for timber production on basis of selective logging. These logging concessions often override traditional land ownership. Shifting cultivation and small holder tree crop production are other main causes for deforestation and forest conversion in Indonesia. In recent years the establishment of small holder tree crop plantations, like rubber, coffee and cacao has increased greatly (Sunderlin \& Resosudarmo 1996). Tree crops are often established in forest clearings near agricultural fields. Logging roads, plantation development, and the infrastructure associated with government sponsored transmigration sites all provide opportunities for small farmers to follow with land clearance of their own (FWI/GWI 2002).

\section{Effects of land-use change on the ecosystem's carbon budget}

Besides its negative effect on species diversity (Reiners et al. 1994; Fujisaka et al. 1998; Murdiyarso et al. 2002), forest conversion also has a profound impact on the ecosystem's carbon budget (Raich 1983; Lal 2005; Jandl et al. 2006). The conversion of natural forests to agricultural systems reduces the carbon stock through the immediate removal of carbon in the aboveground biomass and the slow subsequent decrease in soil organic carbon (van Noordwijk et al. 1997).

The reduction of SOC after forest conversion can be attributed to a number of factors: a decrease in the input of biomass from the vegetation to the soil, an increase in the decomposition rate of organic matter due to alterations in soil moisture and temperature regimes, alterations in quality of $\mathrm{C}$ cycled through the system that replaces the forest (e.g. differences in $\mathrm{C}: \mathrm{N}$ ratio and lignin content of plant biomass), tillage-induced perturbation of the soil, a reduction in physical protection of the soil organic matter and increased soil erosion. Generally, soil C stocks are most susceptible to change at the surface where 
physical changes aggravate processes such as erosion, runoff and leaching (Desjardins et al. 1994).

The greatest alterations in carbon storage per hectare result from the conversion of forests to cultivated land and the reverse: abandonment of croplands to forests (Houghton and Hackler 1999). Activities that do not change the area of forests but do change their standing biomass, like selective logging or shifting cultivation, result in less dramatic changes in the carbon stores. The changes in $\mathrm{C}$ stocks resulting from these activities include both losses and accumulations depending on the balance between decay and regrowth. Management systems that maintain a continuous canopy cover and that mimic regular natural forest disturbance are likely to achieve the best combination of high wood yield and $\mathrm{C}$ storage (Thornley and Cannell 2000). In first instance, more intensively managed tree plantations, secondary forest fallows, and pastures all have greater potential to sequester $C$ than less intensively managed systems. But agricultural intensification may also accelerate $\mathrm{N}$ cycling, which could lead to sub-soil losses of this element and eventually to lower ecosystem productivity. Therefore, the degree in which all agricultural land uses are managed to improve and sustain productivity in the long term will largely determine the magnitude of changes in soil-nutrient dynamics and $\mathrm{C}$ sequestration resulting from forest conversion (McGrath et al 2001).

It is generally accepted that tree-based land uses offer more sustainable alternatives than practices such as cattle ranching and shifting cultivation, in which nutrient cycles are completely disturbed (Smith et al. 1998). The longevity of perennial vegetation promotes a more closed cycling of organic matter and nutrients, thus reducing potential soil degradation (Jordan 1982). However, research quantifying changes in soil carbon contents following forest-to-pasture conversion in Amazonia and other tropical regions has produced conflicting results ranging from net gains to net losses (McGrath et al. 2001). Thus, despite of all the work conducted to quantify changes in soil $\mathrm{C}$ contents induced by forest conversion, it remains unclear exactly how land use change will affect the net balance of soil C. For example, Chen et al. (2005) found that conversion of natural broad-leaved evergreen forests to timber plantations in subtropical China lead to a $25 \%$ reduction of $C$ stocks in the soil (including the organic layer). On the other hand, van Noordwijk et al (1997) hardly found changes in SOC content of the top soil along a gradient of land-use from primary forest to annual crops in upland Sumatra, despite the considerable changes in land use. In a study on C stocks in shaded cacao plantations in Costa Rica both above-ground and soil C stocks were found to increase with time since forest conversion (Koskela et al. 2000). However, even with the relatively high $C$ sequestration in these agroforestry systems, the total $C$ stocks in these systems remained markedly lower than those in the surrounding mature forests. Powers (2004) examined changes in total soil C accompanying different land-use transitions in Costa Rica: conversion of primary forest to banana plantations, conversion of pastures to cash crops and conversion of pastures to tree plantations. Surprisingly, 
conversion of pastures to cash crops reduced soil C concentrations to the same extent as the conversion from forest to banana.

\section{The impact of forest disturbance on the fine root system}

In the study by Powers (2004) described above, 50\% of the differences in soil C concentration between different land use types could be explained by the differences in root biomass and leaf litter pools. Thus, reduced root mass and productivity, and the subsequent reduction in $\mathrm{C}$ input to the soil is an important mechanism explaining decreases in soil $\mathrm{C}$ stocks with land use change. The fine root system (<2 $\mathrm{mm}$ diameter) might be especially important in this respect, as these roots represent the most dynamic part of the root system and mainly occur in the upper soil horizons (Fitter 1996; Vogt et al. 1996; Cairns et al. 1997). Forest disturbance may affect tree fine root biomass through (1) increased soil temperature and reduced topsoil moisture, (2) enhanced mineralization of plant nutrients, and (3) reduced root competition.

Studies on the impact of natural disturbances on fine root systems of tropical forests are rare and studies describing the impact of anthropogenic disturbances are even more sporadic. In a review on this subject Hertel et al. (2007) found that natural disturbances like gap formation through storm events or natural tree fall generally lead to a reduction in fine root biomass. Experimental data of Silver and Vogt (1993) show that a reduction in fine root biomass due to gap formation is a function of gap size. Additionally, the overall effect of disturbance on fine root biomass seems to depend on time. In tropical forests, fine root biomass may reach a minimum shortly after a severe forest disturbance, and may recover over periods of months to years (Parrota and Lodge 1991; Herbert et al. 1999; Arunachalam et al. 1996). The fine root system of old-growth forests is assumed to be able to recover relatively fast after a disturbance event. Monthly fine root recovery rates in tropical forests have been estimated to range between 3.1 and $8.2 \%$ of the initial standing fine root biomass (Hertel et al. 2007). According to this estimate it would take between 32 and 12 months for the fine root system to fully recover after disturbance.

The vertical distribution of fine roots in the soil might also be affected by forest disturbance. Gale and Grigal (1987) hypothesized that late successional species might have a more shallow root distribution than early successional species. This pattern can be ascribed to the vertical decrease in nitrogen and phosphorous availability in the soil. So, if early successional species invade gaps created by forest disturbance events, the overall vertical distribution of fine roots in the soil might be altered. Yang et al. (2004) indeed found more evenly distributed fine root biomass in forest plantations with light demanding tree species in sub-tropical China, compared to that in the adjacent old-growth natural forest. 


\section{Study Area}

The study described in this thesis has been carried out in the surroundings of the village of Toro $\left(01^{\circ} 30^{\prime} \mathrm{S}, 120^{\circ} 02^{\prime} \mathrm{E}\right)$ in the district of Kulawi, Central Sulawesi, Indonesia. Toro is located on the western fringes of Lore Lindu National Park, one of the core areas for the protection of the Wallacea biodiversity hotspot. This mountainous park, with peaks up to $2500 \mathrm{~m}$ a.sl., has been protected since 1993 and harbours some of the largest unbroken tracts of forests on Sulawesi, providing an essential habitat for $73 \%$ of the islands endemic land birds and most of its endangered mammals (The Nature Conservancy 2004).

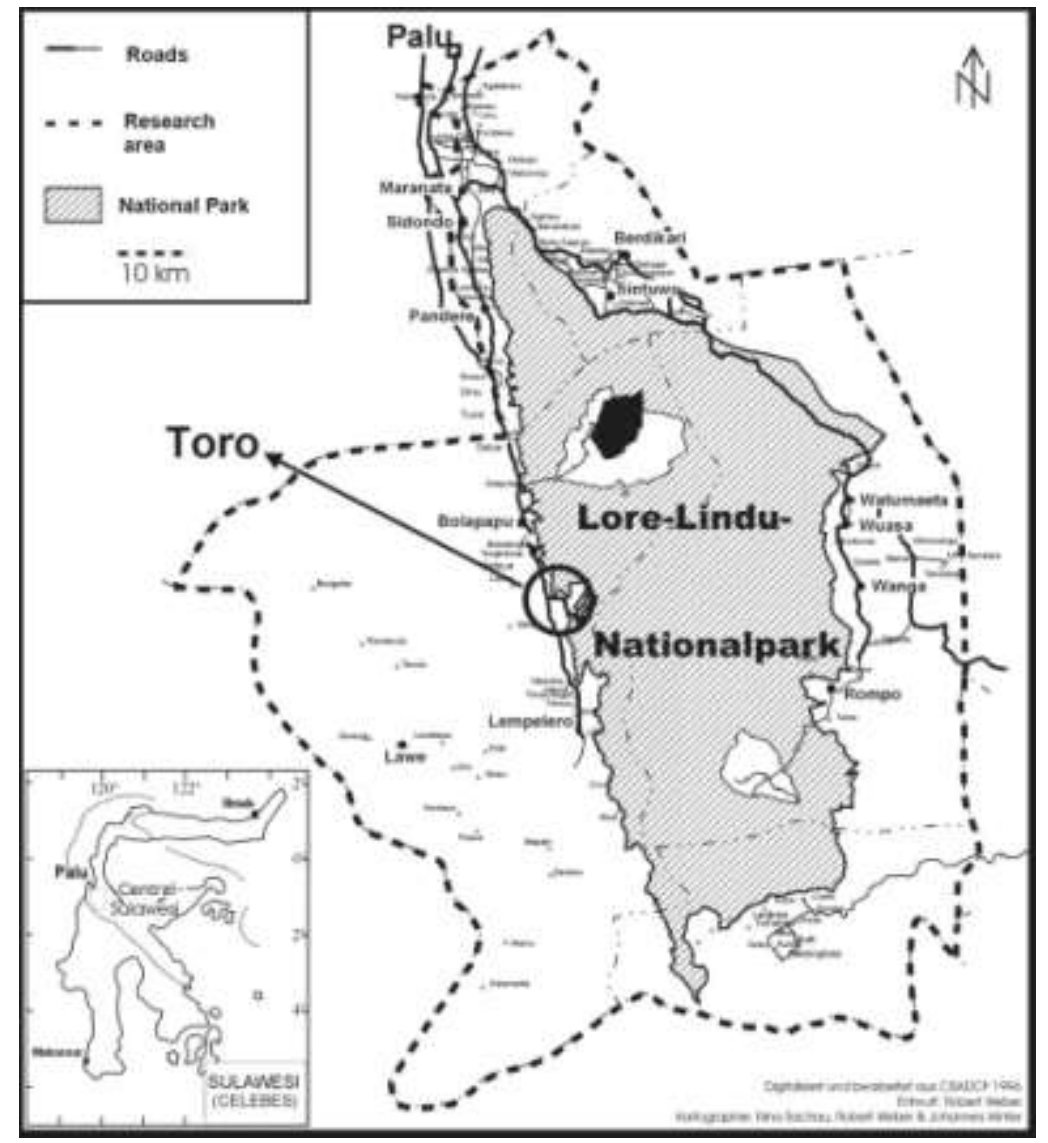

Although the Lore Lindu National Park might not have suffered from the same levels of illegal logging and exploitation as other Indonesian parks, it is surrounded by villages whose inhabitants have made use of the park since generations. As a result, its forests and wildlife are increasingly threatened by agricultural conversion and illegal harvesting of forest resources.

Between 1972 and 2002 approximately $15 \%$ of the Lore Lindu region was deforested and converted to agricultural land. In approximately the same time span, the agroforestry areas in the region more than doubled (Steffan-Dewenter et al. 2007). The cacao agroforestry systems are initiated by intercropping of cacao saplings together with maize (Zea mays) under a sparse shading cover of remaining natural forest trees. In further development 
stages, the entire natural tree cover is replaced by fast growing shade tree species (e.g. Erythrina spp, Gliricidia spp.). The dominant livelihood strategy of the local people in the Lore Lindu region changed from a "food first" approach to a "cash crop first" approach (Steffan-Dewenter et al 2007). This resulted in an increasing pressure for forest conversion and intensification of forest use. Overall, about half of the agricultural area in the Lore Lindu region consists of perennial crops. However, in the districts Palolo and Kulawi, perennials play an even more important role. Here, the area under perennials is twice as large as the area allocated to paddy rice (Maertens et al 2002). In the Lore Lindu Region, almost all agricultural land, including cacao and coffee plantations, are in the hands of small holders. In this region, like in large parts of Indonesia, expansion of small scale farming is a major determinant for deforestation (Maertens et al 2002).

In the Toro valley, the surrounding forests are owned by the local community, although they are part of the Lore Lindu National Park. The village head negotiated a contract with the National Park authorities under which the surrounding forests are being managed as community forests by the villagers. The respective forest area is mapped and classed into forest use types which allow different forms of sustainable forest use, including rattan extraction, selective logging of large-diameter or small-diameter stems, and, locally, conversion to agroforestry systems under a remaining rainforest cover. The forest margin zone is characterised by a gradient of decreasing forest use intensity with distance from the forest edge. From the edge to the interior, alterations occur in structural and functional properties like forest structure, species composition, a diversity, ecosystem function, and economic benefit achieved by extracting forest goods.

A growing proportion of the tropical moist forests will in future survive in a state of low to medium disturbance, as community-based forestry is one of the most promising options for future forest management in Southeast Asia. Despite their increasing importance, few comprehensive studies have been conducted on the relationship between disturbance intensity, biodiversity and ecosystem function in low to moderately disturbed tropical moist forests.

This study was conducted within the framework of the second phase of the SFB project 552: Stability of Rainforest Margins in Indonesia (STORMA). The STORMA project is a multidisciplinary research programme in which Indonesian and European researchers work together to ascertain the socioeconomic drivers and ecological consequences of changes in tropical forest use. Main focal points in the second phase were social and economic dynamics, water and nutrient cycling and biodiversity. In a joint study of plant and animal ecologists on the activity and interaction of roots and animals in the rhizosphere along a forest disturbance gradient, I focussed on fine roots and their importance for rhizosphere carbon dynamics. The central hypothesis of the study was that forest disturbance can have a profound impact on carbon storage and carbon turnover in the below-ground environment of tropical moist forests. 


\section{References}

Achard F., Eva H.D., Stibig H.J. et al., 2002. Determination of deforestation rates of the world's humid tropical forests. Science 297: 999-1002.

Arunachalam A., Pandey H.N., Tripathi R.S. and Maithani K., 1996. Fine root decomposition and nutrient mineralization patterns in a subtropical humid forest following tree cutting. For. Ecol. Manage. 86, 141-150.

Cairns M.A., Brown S., Helmer E.H., Baumgardner G.A., 1997. Root biomass allocation in the world's upland forests. Oecologia 111: 1-11.

Comas L.H., Bouma T.J., Eissenstat D.M., 2002. Linking root traits to potential growth rate in six temperate tree species. Oecologia 132: 34-43.

Chen G.S., Yang Y.S., Xie J.S., Guo J.F., Gao R., Qian W., 2005. Conversion of a natural broad-leafed evergreen forest into pure plantation forests in a subtropical area: effects on carbon storage. Ann. For. Sci. 62: 659-668.

Davidson E.A., Savage K., Bolstad P., Clark D.A., Curtis P.S., Ellsworth D.S., Hanson P.J., Law B.E., Luo Y., Pregitzer K.S., Randolph J.C., Zak D., 2002. Below-ground carbon allocation in forests estimated from litterfall and IRGA-based soil respiration measurements. Agricultural and Forest Meteorology 113: 39-51.

Desjardins T., Andreux F., Volkoff B., Cerri C.C., 1994. Organic-carbon and C-13 contents in soil size-fractions, and their change due to deforestation and pasture installation in eastern Amazonia. Geoderma 61: 103-118.

Dixon R., Brown S., Houghton R.A., Solomon A.M., Trexler M.C., Wisniewski J. 1994. Carbon pools and flux of global forest ecosystems. Science 263: 185-190.

Fitter A., 1996. Characteristics and functions of root systems. In Plant roots: the hidden half. Eds. Y. Waisel, A. Eshel and U. Kafkafi. pp. 1-20. Dekker, New York.

Fujisaka S., Escobar G., Veneklaas E., 1998. Plant community diversity relative to human land uses in Amazonian forest colony. Biodiversity and Conservation 7: 41-57.

FAO, 2005. The state of the world's forests 2005. Global forest resources assessment. FAO Rome.

FWI/GFW, 2002. The State of the Forest: Indonesia. Bogor, Indonesia. Forest Watch Indonesia, and Washington, DC. Global Forest Watch.

Gale M.R., Grigal D.F., 1987. Vertical root distributions of northern tree species in relation to successional status. Can. J. For. Res. 17, 829-834.

Herbert D.A., Fownes J.H., Vitousek P.M., 1999. Hurricane damage to a Hawaiian forest: Nutrient supply rate affects resistance and resilience Ecology 80, 908-920.

Hendrick R.L., Pregitzer K.S., 1992. The demography of fine roots in a northern hardwood forest. Ecology 73: 1094-1104.

Hertel D., Leuschner Ch., 2005. Fine root mass and fine root production in tropical moist forests as dependent on soil, climate and elevation. In Mountains in the mist: Science for conserving and managing tropical montane cloud forests. Eds. L.A. Bruijnzeel and J. Juvik. Hawaii Univ. Press. (in press).

Hertel D., Leuschner Ch., Harteveld M., Wiens M., 2007. Fine root mass, distribution and regeneration in disturbed primary forests and secondary forests of the moist tropics. In: Tscharntke, T., Leuschner, Ch., Zeller, M. (eds.) The Stability of Tropical Rainforest Margins: Linking Ecological, Economic and Social Constraints. Springer, Berlin.

Houghton R.A., Hackler J.L., 1999. Emission of carbon from forestry and land-use change in tropical Asia. Global Change Biology 5: 481-492.

IPCC, 2000. Land use, Land-use change and forestry. Special Report of the Intergovernmental Panel on Climate Change. ISBN: 92-9169-114-3. 
IGBP (International geosphere-biosphere programme), 2001. In: Steffan W., Tyson P. (eds.), Global Change and the earth system: a planet under pressure. IGBP Science 4.

Jackson R.B., Mooney H.A., Schulze E.D., 1997. A global budget for fine root biomass, surface area and nutrient contents. Ecology 94: 7362-7366.

Jandl R., Lindner M., Vesterdal L., Bauwens B., Baritz R., Hagedorn F., Johnson D.W., Minkkinen K., Byrne K.A., 2006. How strongly can forest management influence soil carbon sequestration? Geoderma, doi:10.1016/j.geoderma.2006.09.003.

Janish J.E., Harmon M.E., 2002. Successional changes in live and dead wood carbon stores: implications for net ecosystem productivity. Tree Physiology 22: 77-89.

Janzen H.H., 2004. Carbon cycling in earth systems - a soil science perspective. Agriculture Ecosystems and Environment. 104: 399-417.

Jobbágy E.G., Jackson R.B., 2000. The vertical distribution of soil organic carbon and its relation to climate and vegetation. Ecological Applications 10: 423-436.

Jordan C.F., 1982. The nutrient balance of an Amazonian rain forest. Ecology 63: 647-654.

Koskela J., Nygren P., Berninger F., Luukkanen O., 2000. Implications of the Kyoto Protocol for tropical forest management and land use: prospects and pitfalls. Univ. Helsinki Tropic. Forest. Rep.

Kummerow J., Kummerow M., Souza da Silva W., 1982. Fine-root growth dynamics in cacao (Theobroma cacao). Plant and Soil 65: 193-201.

Lal R., 2005. Forest soils and carbon sequestration. Forest Ecology and Management 220: 242-258.

Lambin E.F., Geist H.J., Lepers E., 2003. Dynamics of land-use and land-cover change in tropical regions. Annu.Rev.Environ.Resour. 28: 205-41

Lehmann J., Zech W., 1998. Fine root turnover of irrigated hedgerow intercropping in Northern Kenya. Plant and Soil 198: 19-31.

Maertens M., Zeller M., Birner R., 2002. Explaining Agricultural Land Use in Villages surrounding the Lore Lindu National Park in Central Sulawesi, Indonesia. STORMA Discussion Paper Series.

Matamala R., Gonzalez-Meler M.A., Jastrow J.D., Norby R.J., Schlesinger W.H., 2003. Impacts of fine root turnover on forest NPP and soil C sequestration potential. Science 302: 1385-1387.

McGrath D.A., Smith C.K., Gholz H.L., de Assis Oliveira F., 2001. Effects of land-use change on soil nutrient dynamics in Amazonia. Ecosystems 4: 625-645.

Murdiyarso D., Van Noordwijk M., Wasrin U.R., Tomich T.P., Gillison A.N., 2002. Environmental benefits and sustainable land use options in the Jambi transect, Sumatra. Journal of Vegetation Science 13: 429-438.

Nadelhoffer K.J., Raich J.W., 1992. Fine root estimates and belowground carbon allocation in forest ecosystems. Ecology 73: 1139-1147.

Nepstad D.C., Verissimo A., Alencar A., Nobre C., Lima E., Lefebvre P., Schlesinger P., Potter C., Moutinho P., Mendoza M., Cochrane M., Brooks V., 1999. Large-scale impoverishment of Amazonian forests by logging and fire. Nature 398: 505-508.

Parrota J.A., Lodge D.J., 1991. Fine root dynamics in subtropical wet forest following hurricane disturbance in Puerto Rico. Biotropica 23, 343-347.

Persson H., 1978. Root dynamics in a young Scots pine stand in Central Sweden. Oikos 30, 508-519.

Pregitzer K.S., Hendrick R.L., Fogel R., 1993. The demography of fine roots in response to patches of water and nitrogen. New Phytologist 125: 575-580.

Pregitzer K.S., Euskirchen E.S., 2004. Carbon cycling and storage in world forests: biome patterns related to forest age. Global Change Biology 10: 2052-2077. 
Powers J.S., 2004. Changes in soil carbon and nitrogen after contrasting land-use transitions in northern Costa Rica. Ecosystems 7: 134-146.

Raich J.W., 1983. Effects of forest conversion on the carbon budget of a tropical soil. Biotropica 15: 177-184.

Raich J.W., Nadelhoffer K.J., 1989. Below-ground carbon allocation in forest ecosystems: global trends. Ecology 70: 1346-1354.

Rasse D.P., Rumpel C., Dignac M.F., 2005. Is soil carbon mostly root carbon? Mechanisms for a specific stabilisation. Plant and Soil 269: 341-356.

Reiners W.A., Bouwman A.F., Parsons W.F.J., Keller M., 1994. Tropical rain forest conversion to pasture: changes in vegetation and soil properties. Ecological Applications 4: 363-377.

Ruess R.W., Van Cleve K., Yarie J., Viereck L.A., 1996. Contribution of fine root production and turnover to the carbon and nitrogen cycling in taiga forest of the Alaskan interior. Canadian Journal of Forest Research-Revue Canadienne de Recherche Forestière 26: 1326-1336.

Sanford R.L., Cuevas E., 1996. Root growth and rhizosphere interactions in tropical forests. In: Mulkey, S.S., Chazdon, R.L., Smith, A.P. (eds.) Tropical forest plant ecophysiology. Chapman and Hall, New York, pp 268-300.

Silver W.L., Vogt K.A., 1993. Fine root dynamics following single and multiple disturbances in a subtropical wet forest ecosystems. Journal of Ecology 81: 729-738.

Silver W.L., Thompson A.W., McGroddy M.E., Varner, R.K., Dias, J.D., Silva, H., Crill, P.M., Kellers, M., 2005. Fine root dynamics and trace gas fluxes in two lowland tropical forest soils. Global Change Biology 11: 290-360.

Six J., Conant R.T., Paul E.A., et al., 2002. Stabilization mechanisms of soil organic matter: implications for C-saturation of soils. Plant and Soil 241: 155-176.

Smith C.K., Gholz H.L., de Assis Oliveira F., 1998. Soil nitrogen dynamics and plant-induced soil changes under plantations and primary terra firme forests in lowland Amazonia, Brazil. Plant and Soil 200: 193-204.

Steffan-Dewenter I., Kessler M., Barkman J., et al., 2007. Tradeoffs between income, biodiversity, and ecosystem functioning during tropical rainforest conversion and agroforestry intensification. PNAS.

Sunderlin W.D., Resosudarmo J.A.P., 1996. Rates and causes of deforestation in Indonesia: towards a resolution of the ambiguities. CIFOR occasional paper nr. 9.

The Nature Conservancy, 2004. Lore Lindu National Park: building partnerships to protect Sulawesi's unique wildlife.

Thornley J.H.M., Cannell M.G.R., 2000. Managing forests for wood yield and carbon storage: a theoretical study Tree Physiology 20: 477-484.

van Noordwijk M., Cerri C., Woomer P.L., Nugroho K., Bernoux M., 1997. Soil carbon in the humid tropical forest zone. Geoderma 79: 187-225.

Vogt K.A., Vogt D.J., Palmiotto P.A., Boon P., O'Hara J., Asbjornsen H., 1996. Review of root dynamics in forest ecosystems grouped by climate, climatic forest type and species. Plant and Soil 187: 159-219.

Xiao C.W., Curiel Yuste J., Janssens I.A., Roskams Nachtergale L., Carrara A., Sanchez B.Y., Ceulemans R., 2003. Above- and below-ground biomass and net primary production in a 73-year-old Scots pine forest. Tree Physiology 23: 505-516.

Yang Y.S., Chen G.S., Lin P., Xie J.S., Guo J.F., 2004. Fine root distribution, seasonal pattern and production in four plantations compared with a natural forest in subtropical China. Annals of Forest Science 61: 617-627. 


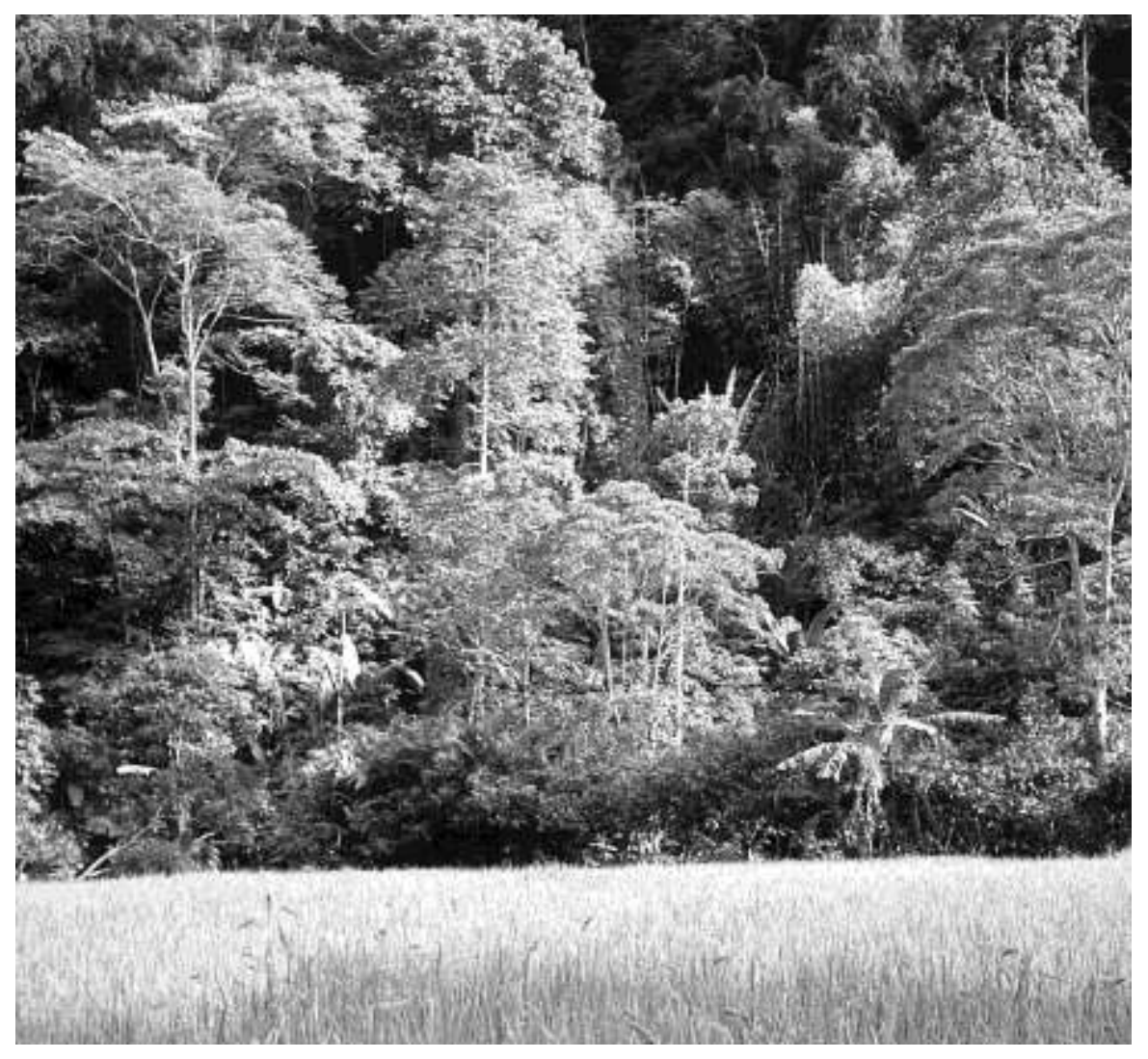




\section{Chapter 2}

\section{Patterns of fine root mass and distribution along a disturbance gradient in a tropical montane forest, Central Sulawesi (Indonesia)}

Ch. Leuschner, M. Wiens, M. Harteveld, D. Hertel, S. Tjitrosemito 
Abstract

Large parts of the remaining tropical moist forests of South-east Asia are encroached at their margins by selective logging, rattan harvesting and the establishment of small agroforest plantations under the rainforest canopy. These slight to heavy disturbances affect aboveground forest structure by reducing wood biomass and canopy cover; however, they may also have a profound impact on the belowground compartment. In a lower montane moist forest of Central Sulawesi, we studied the profile totals of fine root biomass (FRB ${ }_{\text {tot }}$, roots $<2 \mathrm{~mm}$ until $50 \mathrm{~cm}$ of soil depth) and of fine root necromass $\left(F R N_{\text {tot }}\right)$, the vertical distribution of fine root mass, and the fine root live/dead ratio by root coring in 12 forest stands that represented a gradient in forest use (or disturbance) intensity (forest use type A: undisturbed natural forest, B and C: slightly- or moderately disturbed forests with selective timber extraction, D: heavily disturbed cacao agroforest systems under a remaining rainforest cover; each forest types being replicated three times). $F R_{\text {tot }}$ decreased significantly from the forest $A$ to the disturbed $B, C$ and $D$ forests, and reached less than $60 \%$ of the $\mathrm{FRB}_{\text {tot }}$ value of $A$ in the agroforest systems $\mathrm{D}$. A similar decrease with increasing disturbance intensity was found for $\mathrm{FRN}_{\text {tot }}$. Forest disturbance intensity had no significant influence on the vertical distribution of fine root biomass in the profiles. According to correlation and principal component analyses, fractional canopy cover was the most important factor influencing $\mathrm{FRB}_{\text {tot }}$ and $\mathrm{FRN}_{\text {tot }}$, whereas diameter at breast height, stand basal area, stem density, soil $\mathrm{pH}$ and base saturation had only a minor or no influence on root mass. A reduction in canopy cover from 90\% (forest type A) to $75 \%$ (types C and D) was associated with a reduction in $\mathrm{FRB}_{\text {tot }}$ by about $45 \%$ which indicates that timber extraction leads not only to canopy gaps but to corresponding 'root gaps' in the soil as well. We conclude that forest encroachment that is widespread in large parts of South-east Asia's remaining rainforests significantly reduces tree fine root biomass and associated carbon sequestration, even if it is conducted at moderate intensities only.

Key words Agroforestry, canopy gaps, disturbance intensity, fine root biomass, selective logging, vertical root distribution 


\section{Introduction}

In most tropical countries, rainforests are encroached by the local population and converted to agricultural land at constantly high rates (Achard et al., 2002). In many regions of Southeast Asia, only small remnants of natural forest remain today, mainly as protected forest in regional or national conservation areas (Schelhas and Greenberg, 1996). However, many of these remaining forest blocs are currently encroached at their margins by neighbouring villagers or individuals from distant urban regions who use forest products to increase their income. In Indonesia, many formally protected forests actually consist of a more or less undisturbed core zone far from the edge, and a margin zone several hundred $\mathrm{m}$ to a few $\mathrm{km}$ wide with slight to heavy human impact and increasing degradation (Collins et al., 1991).

Rattan extraction, selective logging of a limited number of trees and the creation of small gaps for establishing crop plantations inside the forest are typical activities in the margin zone of most Indonesian national parks and forest reserves (FWI/GFW, 2002). Since these activities in the forest margin zone are primarily controlled by the proximity of access roads and tracks, human impact is rapidly decreasing with growing distance from the forest edge. Typically, a steep gradient of forest use intensity from the forest interior toward the margin exists which is accompanied by an increase in the size and number of canopy gaps. Since there is a steady increase in the proportion of tropical forest which is left in a disturbed state, a better understanding of the effects of low- and moderate-intensity disturbances on soil processes, vegetation and fauna of tropical forests is urgently needed.

The study of the ecological consequences of disturbance in tropical forests has focused on the aboveground compartment. Studies have been undertaken only recently to investigate belowground changes after canopy gap formation in tropical forests (Ostertag, 1998; Sanford, 1989, 1990; Silver and Vogt, 1993; Uhl et al., 1988; Vitousek and Denslow, 1986). Most of these studies refer to gap formation by senescing trees, windbreaks and other natural disturbances in Neotropical forests where human impact played a minor role. These results may not be applicable to human-induced disturbances where small gaps are created due to the harvesting of single trees. This situation includes the extraction of wood biomass which is not left in place for decay as is the case during natural disturbances.

This paper investigates the effects of variable intensities of forest use on the tree fine root system of tropical lower montane moist forests in Central Sulawesi, Indonesia. We studied the profile totals, the vertical distribution and the live/dead ratio of fine roots (diameter $<2$ $\mathrm{mm}$ ) in a gradient from negligibly disturbed forest (natural forest) to selectively logged, slightly disturbed forest, to moderately disturbed forest, and finally to a heavily disturbed cacao agroforest system with remaining forest shade trees which replaces the natural forest in many areas of the region. These four forest use types are characteristic elements of the forest margin zone in Sulawesi and in other parts of South-east Asia. We related the root system properties to stand structural and canopy characteristics in order to analyse putative interactions between canopy and fine root system. We tested the hypothesis of Wilczynski 
and Pickett (1993) that increasing canopy gaps after disturbance are associated with gaps in the root system as well, leading to reduced total fine root biomass in the disturbed forests.

\section{Material and methods}

\section{Study sites}

The study was conducted in the surroundings of the village of Toro in the province of Donggala, Central Sulawesi, Indonesia $\left(01^{\circ} 30^{\prime} \mathrm{S}, 120^{\circ} 02^{\prime} \mathrm{E}\right)$. Toro is located on the western fringes of Lore Lindu National Park, one of the last larger areas of tropical montane forest in the region which is protected since 1993. The study sites are situated in rugged terrain on moderately steep slopes $\left(17-39^{\circ}\right)$ in the lower montane belt (elevation $815-1130 \mathrm{~m}$ a.s.I.). The soils in the Toro region derived either from sedimentary rocks or from tertiary intrusives; the soil types are predominantly well drained Orthieutric and Hypereutric Cambisols (FAO classification) with relatively high fertility. There is a considerable pedologic heterogeneity in the region; locally, Orthidystric Cambisols and Haplic Ferralsols are also present. The base saturation of the topsoil varied between 34 and $99 \%$, the $\mathrm{pH}(\mathrm{KCl})$ between 3.2 and 6.4 (Table 1, unpubl. data from Häring). Mean annual air temperature in Toro is about $24{ }^{\circ} \mathrm{C}$, yearly average precipitation about $2200 \mathrm{~mm}$. Rainfall shows a moderate seasonality with at least $100 \mathrm{~mm}$ per month falling throughout the year. Typically, rainfall occurs on 20 to 30 days per month. Air humidity ranges mostly between 75 and $90 \%$ throughout the year. December, January and February are often somewhat drier months. The study year (2004) was no ENSO (EI Nino Southern Oscillation) year with associated drought periods.

The natural forest vegetation in the region is a fairly species-rich lower montane moist forest with a height of 35 to $45 \mathrm{~m}$. Common tree genera on the study plots include Castanopsis (Fagaceae), Chionanthus (Oleaceae), Dysoxylum (Meliaceae), Ficus (Moraceae) and Lithocarpus (Fagaceae) (Pitopang et al., 2005).

We studied four types of woody vegetation in the forest margin zone which represent typical stages of a gradient in forest use intensity in the Lore Lindu region:

- Forest use type $A$ is an old-growth natural forest with only minor indication of human impact. Canopy cover is about $90 \%$ with no major gaps being present. Timber has been extracted only very exceptionally, and the plots were chosen in patches where no signs of cutting were found. However, extraction of rattan (Calamus sp.) was widespread in all types of forest in the region including the natural forest. Today, rattan is very rare even in forest use type $A$.

- Forest use type B is a slightly-disturbed forest in which small-diameter stems of the lower canopy stratum are being selectively extracted at irregular intervals. Canopy cover is only a few percent lower than in type A.

- $\quad$ Forest use type $C$ is termed a moderately-disturbed forest because selective extraction of large-diameter timbers irregularly takes place. As a consequence, small gaps are occurring in the upper canopy (canopy cover about $80 \%$ ) with the 
consequence that young trees with small diameters are thriving in the gaps forming small thickets that are mostly in the stem-exclusion phase of stand development (Table 1).

- $\quad$ Forest use type $\mathrm{D}$ is an agroforest system with cacao (Theobroma cacao L.) planted in the understorey of a sparse cover of remaining rainforest trees that cast shade on the plantation. In contrast to the types $\mathrm{A}-\mathrm{C}$, a scattered layer of mainly invasive herbs and grasses covers the soil surface. With respect to forest structure, this vegetation type is classified as 'heavily disturbed'.

All four forest use types are widespread in the Lore Lindu region. In the Toro valley, the surrounding forests are owned by the local community, although they are part of the Lore Lindu National Park. The village head (kepala desa) negotiated a contract with the National Park authorities under which the surrounding forests are being managed as community forests by the villagers. The respective forest area is mapped and classed into forest use types which allow different forms of sustainable forest use, including rattan extraction, selective logging of large-diameter or small-diameter stems, and, locally, conversion to agroforest systems under a remaining rainforest cover. Our four forest use types $A-D$ match these management systems of community forestry.

We selected 12 study plots of $50 \times 50 \mathrm{~m}$ in the region with each forest use type being represented in triple replication. Selection criteria were (1) good coincidence with the structurally-defined four forest use types described above, (2) sufficient comparability of the three replicate stands with respect to forest structure, (3) sufficient spatial homogeneity of the plots, and (4) a defined and temporarily stable management system, i.e. the existence of a non-disputed forest utilization contract between village head and user.

\section{Analysis of aboveground forest structure and soil chemical parameters}

The canopy cover of the 12 research plots was measured with a spherical densiometer. At 10 randomly selected locations per plot, readings were done in 4 directions, north, south, east and west. The average of the four readings was used as one measurement.

On all study plots, all stems with a diameter $>10 \mathrm{~cm}$ for diameter at breast height (DBH) and tree height were investigated (unpubl. data of J. Dietz). In addition, three subplots of $5 \times 5 \mathrm{~m}$ were randomly selected per plot in which all individuals taller than $2 \mathrm{~m}$ were measured. Tree height measurements were taken with the Hagloef Vertex III Ultrasonic device, DBH was recorded with a measuring tape at $1.3 \mathrm{~m}$ height. All data were related to ground area and subsequently corrected for slope angle. Cumulative basal area and stem density were then expressed per hectare. $\mathrm{pH}$ (detected in $1 \mathrm{M} \mathrm{KCl}$ ) and base saturation (sum of basic cations in percent of cation exchange capacity) were measured in spring 2005 in each four soil pits per study site in the uppermost soil horizon $(0-10 \mathrm{~cm}$, all analyses by V. Häring, unpubl. data); in addition, organic layer thickness was also determined. 
Table 1 Structural characteristics and soil parameters of the 12 studied plots in the 4 forest use types A - D (structural data from J. Dietz). $\mathrm{pH}$ and base saturation refer to the topsoil $(0-10 \mathrm{~cm})$. Organic layer depth in $\mathrm{mm}, \mathrm{pH}$ and base saturation as measured in spring 2005 by V. Häring. Different letters indicate significant differences among forest use types.

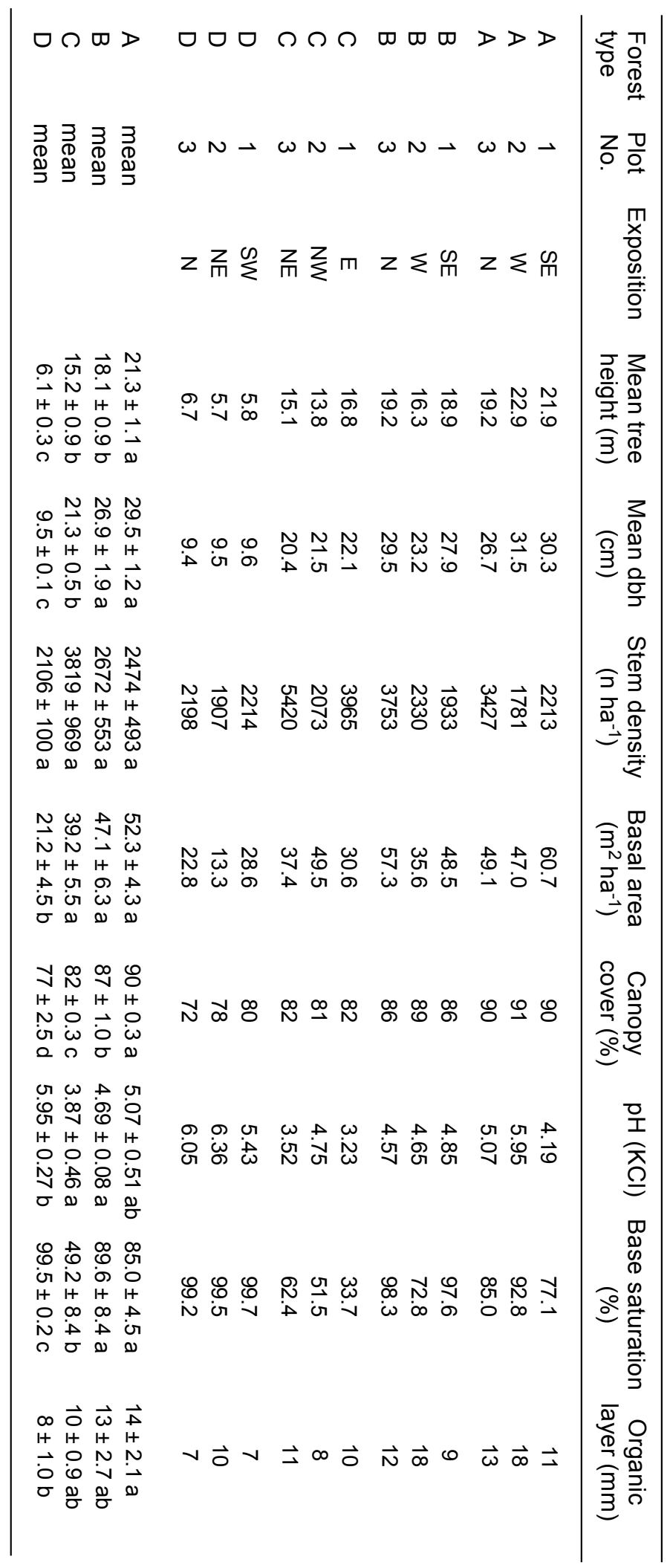




\section{Root sampling and root analyses}

Root samples were taken with a soil corer $(3.5 \mathrm{~cm}$ in diameter) from the organic layer and the mineral soil down to $50 \mathrm{~cm}$ soil depth at six randomly selected sampling locations per study plot. The sampling points were located at a minimum distance to each other of $5 \mathrm{~m}$ in order to avoid clumping of the locations and to cope with the considerable spatial heterogeneity of many plots. Soil cores were taken at six depths (organic horizon, mineral soil at $0-10,10-20,20-30,30-40$ and $40-50 \mathrm{~cm}$ depth). The soil samples were transferred to plastic bags and transported to the laboratory at the University of Palu where processing of the samples stored at $4^{\circ} \mathrm{C}$ took place within 60 days. In the lab, the samples were soaked in water and cleaned from soil residues using a sieve with a mesh size of $0.25 \mathrm{~mm}$. Large root fractions (> $10 \mathrm{~mm}$ in length) were extracted by hand. Only fine roots of trees (roots $<2 \mathrm{~mm}$ in diameter) were considered for analysis. Roots of grasses and herbs, which only were abundant in the agroforestry systems, were easily distinguished from tree fine roots by their smaller diameter and light colour. Live (biomass) and dead rootlets (necromass) were distinguished under the stereomicroscope by color, root elasticity, and the degree of cohesion of cortex, periderm and stele. A dark cortex and stele, or a white, but non-turgid cortex, or the complete loss of the stele and cortex with only the periderm being present, were used as indicators of root death (Leuschner et al., 2001; Persson, 1978). The collected fine root fraction covered the large majority of the living fine root mass, but it included only a small part of the necromass, because detritus-like fractions of dead roots, that may account for a large portion of the whole necromass (Bauhus and Bartsch, 1996; Hertel, 1999), were recovered only to a small extent with this method. Therefore, one third of the samples was subjected to an additional, more detailed analysis of small fine root necromass particles (< $10 \mathrm{~mm}$ in length) applying a method introduced by van Praag et al. (1988) and modified by Hertel and Leuschner (2002). After extraction of the large root fractions, the residue of the sample was evenly spread on a large sheet of filter paper $\left(730 \mathrm{~cm}^{2}\right)$ with 36 squares marked on it. Six of the squares were randomly selected and analysed under the stereomicroscope for even smallest dead fine root fragments. These decaying root particles may represent the main part of the fine root necromass (Bauhus and Bartsch, 1996; Hertel 1999). The mass of small dead rootlets was extrapolated to the entire sample by means of the ratio of small rootlets to large dead roots (>10 $\mathrm{mm}$ in length) that was established in a sub-sample. Fine root biomass (FRB) and necromass (FRN) of each sample were dried at $70{ }^{\circ} \mathrm{C}$ for $48 \mathrm{~h}$ and weighed. The fine root biomass/necromass ratio was then calculated for each sample. The data were expressed in relation to soil volume as fine root mass density (in $\mathrm{g} \mathrm{L}^{-1}$ ) for different soil depths, and as profile total of FRB or FRN (organic layer plus $0-50 \mathrm{~cm}$ of the mineral soil; $\mathrm{FRB}_{\text {tot }}$ or $\mathrm{FRN}_{\text {tot }}$ in $\mathrm{g} \mathrm{m}^{-2}$ ). 


\section{Statistical analyses}

We used the equation proposed by Gale and Grigal (1987) to describe the exponential decrease of fine root biomass with soil depth for all 12 study plots: (1) $y=1-\beta^{d}$, ( $y$ is the cumulative fraction of total fine root biomass from the soil surface to a depth of $d \mathrm{~cm}$ ). $\beta$ values typically range between 0.80 and 0.99 for tree fine root systems; low $\beta$ values indicate a more gradual biomass decrease with depth, high $\beta$ values reflect a more superficial root distribution and a rapid decrease with depth. The surface of the organic layer was used as the zero point of the curves, or, in other words, the thin organic layer was treated as the uppermost soil horizon. The regression fits were calculated with the software package Xact (version 7.12, SciLab, Hamburg, Germany).

Probability of fit to normal distribution was tested by a Shapiro-Wilk test. With only a few exceptions, the root mass and stand structural data showed non-gaussian distribution; consequently, non-parametric tests were used. The fine root mass data were compared among the four forest use types with one-way Kruskal-Wallis single factor analyses of variance. A non-parametric Mann and Whitney U-test was used for pair-wise comparison of significant differences between the types ( $p<0.05$ in all analyses). These calculations were conducted with the software package SAS, version 8.01 (SAS Institute, Cary, NC, USA). To analyse the differentiation of the 12 study plots with respect to several stand structural and abiotic characteristics, we conducted a Principal Components Analysis. The matrix species factors were: study plot, canopy cover, basal area, stem density, mean diameter at breast height $(\mathrm{DBH}), \mathrm{FRB}_{\text {tot }}, \mathrm{FRN}_{\text {tot }}$, FRB/FRN ratio, and $\mathrm{pH}(\mathrm{KCl})$ and base saturation of the upper mineral soil $(0-10 \mathrm{~cm})$. The PCA analyses were conducted with the package CANOCO, version 4.5 (Biometris, Wageningen, The Netherlands). The dependence of $\mathrm{FRB}_{\text {tot }}, \mathrm{FRN}_{\text {tot }}$ and FRB/FRN ratio on canopy cover, stem density, and basal area was also analysed by single-factor linear, or non-linear regression analyses (package Xact). The dependence of $\mathrm{FRB}_{\text {tot }}$ and $\mathrm{FRN}_{\text {tot }}$ on various biotic and abiotic site factors was further analysed by multiple regression analysis (SAS, version 8.01).

\section{Results}

\section{Stand structure}

From natural forest with negligible disturbance (forest use type $A$ ) to the slightly-disturbed forests (type $B$ ) and further to the moderately-disturbed forests (type $C$ ), there was a general decrease in mean tree height (from 21.3 to $15.2 \mathrm{~m}$ ), in DBH (30 to $21 \mathrm{~cm}$ ), in stand basal area (52 to $39 \mathrm{~m}^{2} \mathrm{ha}^{-1}$ ) and in canopy cover (90 to $82 \%$ ), despite considerable variation among the three replicate stands of a forest use type and, thus, non-significant differences between types $A$ and $B$ in several cases (Table 1). The forest use type $D$ (heavily disturbed cacao agroforest system) had the smallest mean tree height, mean $\mathrm{DBH}$, stand basal area 
and canopy cover of all four forest use types. Stem density showed no trend in this sequence of increasing disturbance intensity.

\section{Fine root abundance and distribution patterns}

Root coring in the organic layer and the mineral soil to a depth of $50 \mathrm{~cm}$ showed highly different profile totals of fine root biomass in the 12 forest stands. Based on each 6 soil profiles investigated per stand, we found a maximum value of $655 \mathrm{~g} \mathrm{~m}^{-2}$ (stand B2) and a minimum of $101 \mathrm{~g} \mathrm{~m}^{-2}$ (B3). With a mean of $408 \mathrm{~g} \mathrm{~m}^{-2}$, the three natural forest stands (A1 A3) had a significantly larger $\mathrm{FRB}_{\text {tot }}$ value than all other forest use types. Second were the slightly-disturbed forests (B1- B3), followed by the moderately-disturbed forests (C1 - C3) and the heavily disturbed agroforest systems (D1 - D3). The forest use types B, C and D did not differ significantly from each other, although the mean of type B was by $90 \mathrm{~g} \mathrm{~m}^{-2}$ larger than the means of $C$ and $D$.

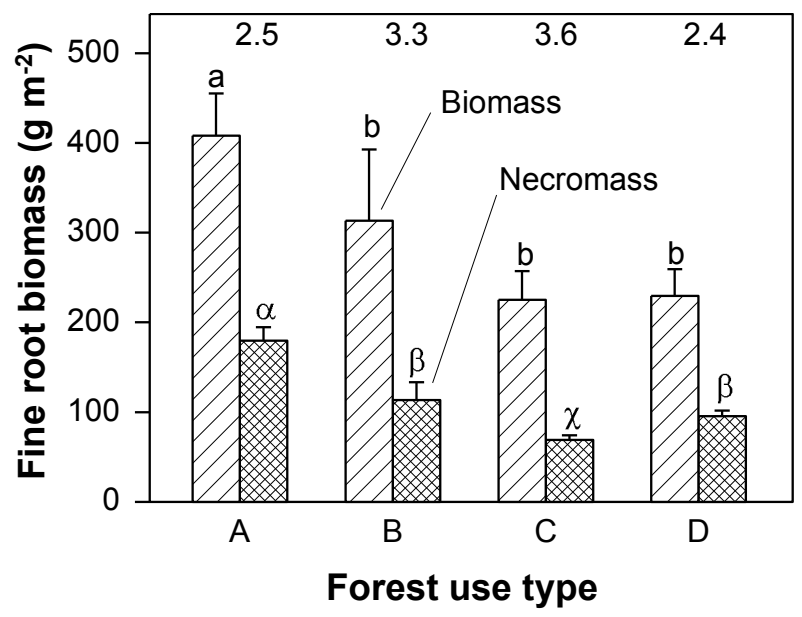

Figure 1 Profile totals of fine root biomass (FRB) and necromass (FRN) in the four forest use types $A$ to $D$ (means $+1 \mathrm{SE}$ of each 3 plots with 6 profiles per plot investigated). Profile total = organic layer plus $0-50 \mathrm{~cm}$ of mineral soil. Numbers in headline = mean FRB/FRN ratios of the profiles. Different Latin or Greek letters indicate significant differences in FRB or FRN between the forest use types.

In all stands (except for B3), we found more fine root biomass than necromass (FRN) in the profiles. As for $\mathrm{FRB}_{\text {tot }}$, the 12 stands showed a large variation in the profile totals of necromass (FRN $N_{\text {tot }}: 54$ to $207 \mathrm{~g} \mathrm{~m}^{-2}$ in the organic layer plus $0-50 \mathrm{~cm}$ of mineral soil). There was a significant decrease from the natural forests $(A)$ to the slightly-disturbed forests $(B)$ and further to the moderately-disturbed forests (C, Figure 1). The agroforest systems (D) differed significantly from the type $C$ forests, but not from the type $B$ forests. The average fine root biomass/necromass ratio in the profiles increased from 2.5 in the type A forests to 3.3 in type $B$ and 3.6 in the type $C$ forests (differences not significant). The agroforest systems tended to have the smallest mean FRB/FRN ratio.

In all 12 stands, fine root biomass density decreased exponentially with soil depth from high concentrations in the organic layer $\left(2.5-5.0 \mathrm{~g} \mathrm{~L}^{-1}\right)$ to low densities at $20-30 \mathrm{~cm}$ depth $(0.2-$ 
$\left.0.6 \mathrm{~g} \mathrm{~L}^{-1}\right)$ and below $\left(<0.5 \mathrm{~g} \mathrm{~L}^{-1}\right.$ at $30-50 \mathrm{~cm}$, Figure 2a). Exponential functions of the form $\mathrm{y}$ $=1-\beta^{\mathrm{d}}(\mathrm{y}=$ cumulative fine root biomass, $\mathrm{d}=$ soil depth) had similar $\beta$ factors in all stands (0.83 to 0.91 ) although root mass was significantly higher in type $A$ than in the other forest use types. Fine root necromass also decreased exponentially with depth from high densities in the organic layer $\left(1.0-4.5 \mathrm{~g} \mathrm{~L}^{-1}\right)$ to low values at $10-20 \mathrm{~cm}$ and below $\left(<0.3 \mathrm{~g} \mathrm{~L}^{-1}\right.$, Figure 2b).

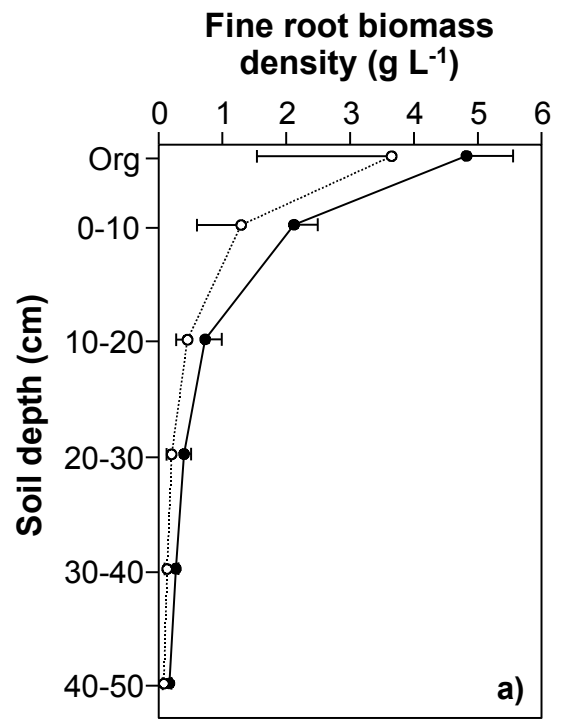

\section{Fine root necromass density $\left(\mathrm{g} \mathrm{L}^{-1}\right)$}

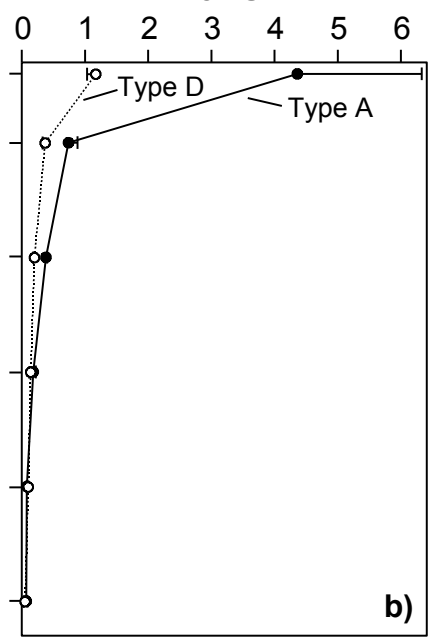

Figure 2 Density (mass per volume) of fine root biomass (a) and fine root necromass (b) in soil profiles of natural forest (Type A) and agroforest (Type D). Mean \pm 1 SE of 3 plots per forest use type with each 6 profiles investigated.

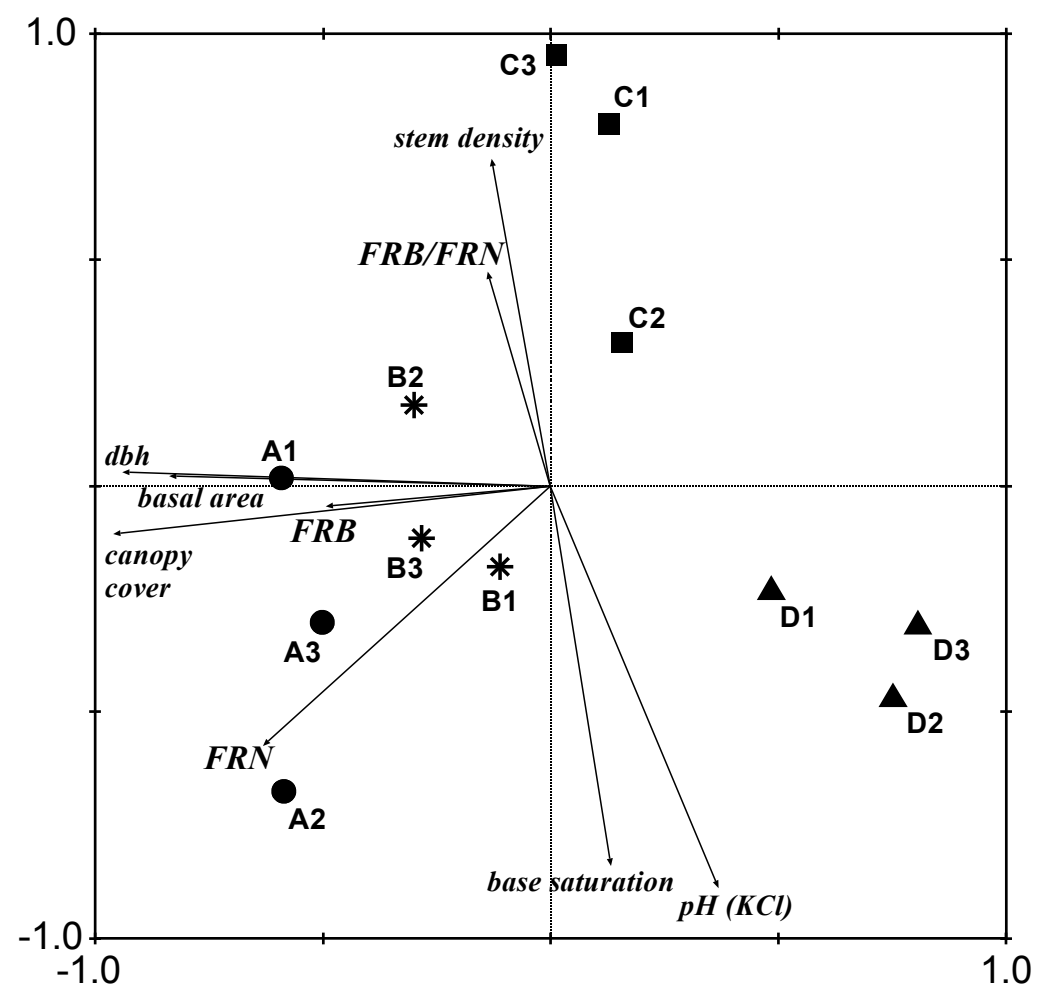

Figure 3 Plot showing the distribution of the 12 study plots (numbered A1 to D3) in PCA axes 1 and 2 together with stand structural and soil chemical variables. Vector length and angle are proportional to the direction and degree of their correlation with the plot ordination scores. 


\section{Influence of stand structure and soil acidity on fine root mass}

The results of a principle component analysis (PCA) based on stand structural and abiotic characteristics showed a clearer differentiation between the four forest use types $(A-D)$ than between the each three replicate stands within a type: The PCA separated the four forest use types along the first axis (eigenvalue $=0.429$ ) in the sequence $A-B-C-D$ (Fig. 3). This axis was related to the parameters canopy cover, DBH and basal area of the stands, and thus expressed the disturbance gradient. Fine root biomass showed a close correlation to these above-ground stand characteristics; in contrast, fine root necromass was less correlated. The factor with the strongest influence on the profile totals of fine root biomass in the 12 stands was canopy cover.

The second axis (eigenvalue $=0.261$ ) coincided with the factors stem density and, in opposite direction, with topsoil base saturation and $\mathrm{pH}$, factors of secondary importance in the explanation of plot similarity. Stem density was particularly high in the larger gaps of the C-type forests where vital tree regrowth occurred. The FRB/FRN ratio was positively related to stem density, but negatively to base saturation.
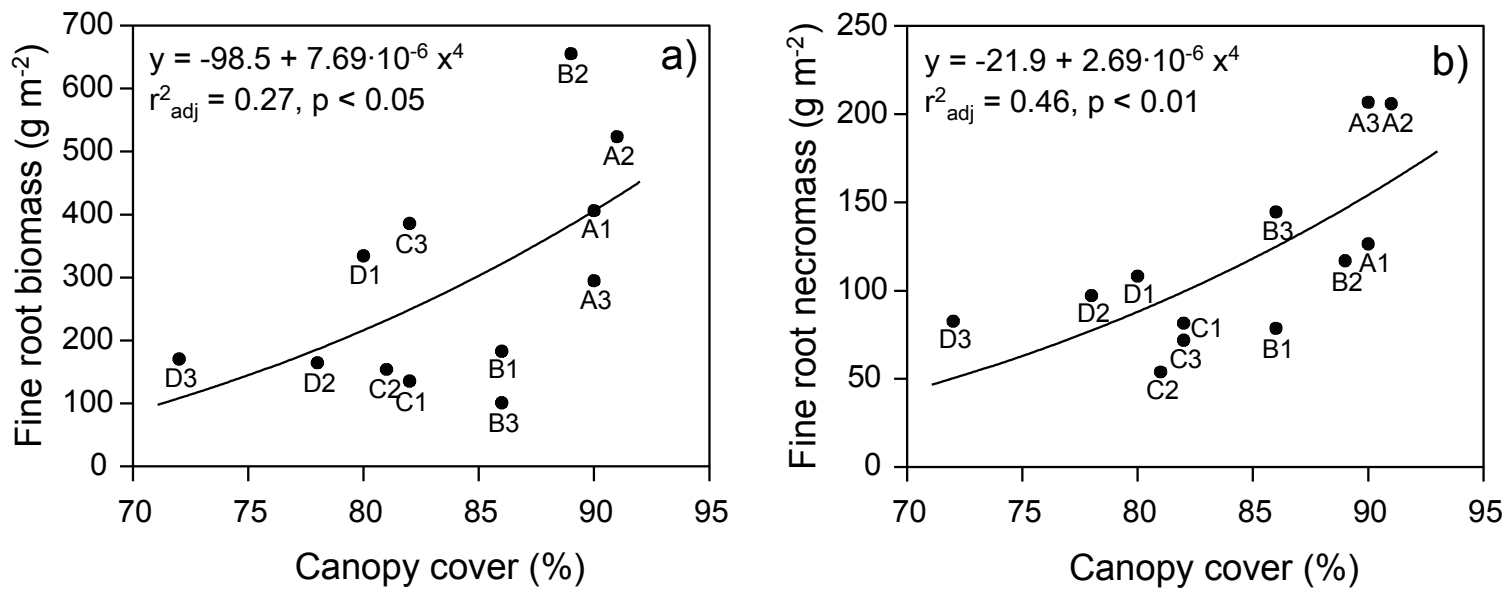

Figure 4 Relationship between canopy cover and fine root biomass (a) or fine root necromass (b) for the 12 studied plots in the four forest use types $A$ to $D$.

We fitted an exponential equation to describe the positive relation between canopy cover and $\mathrm{FRB}_{\mathrm{tot}}\left(\mathrm{r}_{\text {adj }}^{2}=0.27, \mathrm{p}<0.05\right)$. Accordingly, fine root biomass increased by more than $100 \%$ from a forest with $75 \%$ canopy cover to a stand with $90 \%$ cover (Fig. 4a). Canopy cover had a similar effect on fine root necromass (Fig. 4b). In contrast to the PCA results, we did not find a significant influence of stand basal area on $\mathrm{FRB}_{\text {tot }}$ in the single-factor correlation analysis (Table 2). A linear multiple regression analysis with stepwise variable selection gave canopy cover as the variable with strongest influence on $\mathrm{FRB}_{\mathrm{tot}}$, followed by DBH (Table 3). Fine root necromass was found to be primarily influenced by canopy cover and $\mathrm{pH}(\mathrm{KCl})$. 
Table 2 Correlation coefficients of linear or exponential $\left(^{*}\right)$ regressions of canopy cover, basal area and $\mathrm{DBH}$ on profile totals of fine root biomass (FRB), fine root necromass (FRN) or the FRB/FRN ratio in the soil profile.

\begin{tabular}{lllrr}
\hline Parameter & Source & $r$ & $r^{2}{ }_{\text {adj }}$ & $p$ \\
\hline \multirow{2}{*}{ Fine root biomass } & Canopy cover* & $\mathbf{0 . 5 8}$ & $\mathbf{0 . 2 7}$ & $<\mathbf{0 . 0 5}$ \\
& Basal area & 0.11 & -0.01 & 0.73 \\
& dbh & 0.26 & 0.00 & 0.33 \\
Fine root necromass & Canopy cover* & $\mathbf{0 . 7 1}$ & $\mathbf{0 . 4 6}$ & $<\mathbf{0 . 0 1}$ \\
& Basal area & 0.36 & 0.05 & 0.24 \\
& dbh & $\mathbf{0 . 6 4}$ & $\mathbf{0 . 3 5}$ & $<\mathbf{0 . 0 5}$ \\
Biomass/necromass & Canopy cover & 0.15 & -0.08 & 0.65 \\
ratio & Basal area & -0.06 & -0.10 & 0.85 \\
& dbh & -0.04 & -0.10 & 0.91 \\
\hline
\end{tabular}

Table 3 Results of a multiple linear regression of several stand structural and abiotic variables on profile totals of fine root biomass or fine root necromass of the 12 plots. The variables were added in a stepwise manner.

\begin{tabular}{|c|c|c|c|}
\hline Parameter $(Y)$ & Source & $\mathrm{F}$ value & $\mathrm{p}$ \\
\hline \multirow[t]{8}{*}{ Fine root biomass } & Basal area & 0.41 & 0.55 \\
\hline & Base saturation & 0.18 & 0.67 \\
\hline & Canopy cover & 12.03 & 0.01 \\
\hline & $\mathrm{DBH}$ & 6.07 & 0.04 \\
\hline & $\mathrm{PH}(\mathrm{KCl})$ & 0.64 & 0.46 \\
\hline & Stem density & 0.29 & 0.62 \\
\hline & Tree height & 3.23 & 0.12 \\
\hline & Intercept & 10.76 & 0.01 \\
\hline Regression model & \multicolumn{2}{|c|}{$y=49.7 \cdot$ canopy cover $-23.8 \cdot d b h-3342$} & $r^{2}=0.63, p=0.02$ \\
\hline \multirow[t]{8}{*}{ Fine root necromass } & Basal area & 0.21 & 0.67 \\
\hline & Base saturation & 0.00 & 0.96 \\
\hline & Canopy cover & 13.00 & 0.01 \\
\hline & $\mathrm{DBH}$ & 0.92 & 0.38 \\
\hline & $\mathrm{pH}_{\mathrm{KCl}}$ & 6.30 & 0.04 \\
\hline & Stem density & 3.53 & 0.10 \\
\hline & Tree height & 0.34 & 0.58 \\
\hline & Intercept & 10.2 & 0.01 \\
\hline Regression model & \multicolumn{2}{|c|}{$y=5.8 \cdot$ canopy cover $+22.9 \cdot p H_{K C l}-488$} & $r^{2}=0.66, p=0.01$ \\
\hline
\end{tabular}




\section{Discussion}

\section{Fine root biomass of undisturbed forest}

The largest profile totals of fine root biomass of all four land use types in the forest margin zone were found in the natural forest stands with only negligible disturbance (forest use type A). Our average fine root biomass totals from a lower montane region $\left(408 \pm 66 \mathrm{~g} \mathrm{~m}^{-2}\right.$ for organic layer plus $0-50 \mathrm{~cm}$ of the mineral soil, mean $\pm 1 \mathrm{SE}$ ) are in good agreement with data from 55 observations in other tropical moist forests of the globe, which average at $451( \pm 45)$ $\mathrm{g} \mathrm{m}^{-2}$ (in the majority of studies: 0 to $50 \mathrm{~cm}$ depth) although root biomass can differ largely between stands depending on tree species, soil conditions and profile depth analysed (Hertel and Leuschner, 2005).

The average values for old-growth forests from the current study are also close to those obtained from temperate deciduous forests. In a meta-analysis of 129 studies on temperate broad-leaved and coniferous forests, Leuschner and Hertel (2002) reported a mean of 442 $( \pm 21) \mathrm{g} \mathrm{m}^{-2}$. The variation in fine root biomass among different stands was considerably lower in our meta-analysis than in earlier ones conducted by Jackson et al. (1996) or Vogt et al. (1996) because we strictly included only data with roots $<2$ or $3 \mathrm{~mm}$ in diameter and only considered live roots, whereas these authors were less rigid in their selection criteria. This data compilation allows to conclude that the average fine root biomass of the tropical and temperate forests is rather similar despite striking differences in climate, phenology, aboveground biomass and, most often, leaf area index, attributes which most likely are linked to differences in nutrient demand and nutrient supply between tropical and temperate forests.

\section{Effects of forest disturbance on stand fine root biomass and its distribution}

How do selective logging and associated disturbances affect profile totals and spatial distribution of tree fine roots in tropical forests? In theory, human-induced gap formation could act on the fine root system of trees through several causal chains, (1) by altering the thermal and moisture regimes in the gap, (2) by increasing or decreasing nutrient supply through altered litter supply rates and microbial activities, and (3) by changing above-ground stand structure which may interact with the root system.

Our fine root biomass data from 12 forest stands which differed in disturbance intensity and the size of gap fraction showed that moderate to high levels of timber removal lead to a significant and lasting reduction in the profile totals of fine root biomass. However, according to the PCA and the correlation analyses, basal area and its reduction was not the principal structural parameter influencing fine root biomass totals. This is astonishing and may probably be explained by root competition. We hypothesize that competition among fine roots is intense in the topsoil of old-growth forests in tropical and temperate climates. A reduction in stem density with selective logging must cause root dieback in the gaps and 
thus may partly release the remaining roots from competition. A likely response is enhanced fine root growth by the remaining trees into the gaps, if the openings are sufficiently small. If timber extraction is of low intensity, this effect will partly compensate for the loss in fine root biomass and, thus, may obscure any relation between wood extraction or basal area reduction and a decrease in $\mathrm{FRB}_{\text {tot }}$.

Our data showed no effect of stem density on $\mathrm{FRB}_{\text {tot }}$, but they indicated a principal role of canopy cover on stand fine root biomass, albeit at a low degree of determination $\left(r^{2}=0.27\right)$. Accordingly, a reduction in canopy cover from $90 \%$ (closed natural forest, type A) to $75 \%$ (moderately-disturbed forest, type C) led to an over-proportional reduction (by $45 \%$ ) in fine root biomass. Other studies of small, localized disturbances in tropical forests due to natural tree fall indicated in most cases a reduction in $\mathrm{FRB}_{\text {tot }}$ in the gaps compared to intact forest (Denslow et al., 1998; Ostertag, 1998; Sanford, 1989, 1990; Silver and Vogt, 1993). Similarly, Sundarapandian and Swamy (1996) reported a significantly lowered fine root biomass total and also fine root production under open canopies compared to closed canopies in evergreen moist forest in India. The above cited studies further indicate that the decrease in fine root biomass tends to increase with the size of the gap.

The extent of fine root biomass reduction after disturbance seems to depend on time. FRB $\mathrm{Ft}_{\text {tot }}$ may reach a minimum shortly after a severe disturbance and may recover over periods of months to years (Arunchalam et al., 1996; Herbert et al., 1999). Parrota and Lodge (1991) observed a sharp decrease in fine root biomass after hurricane disturbance in a tropical moist forest in Puerto Rico and concluded that at least one year was required for the reestablishment of the original root mass. The cited results are in general accordance with our data; however, none of the cited studies differentiated between the possible effects of altered canopy cover, basal area and stem density, factors which all might influence fine root biomass.

If canopy cover (or leaf area index), but not stem density, basal area or functional attributes such as stand sapwood area, were indeed the most important variables influencing FRB tot $_{\text {, }}$ canopy gaps with reduced leaf area should coincide with reduced fine root densities in the soil. This would partly support the root gap theory of Wilczynski and Pickett (1993) which predicts a less closed 'root canopy' after disturbance of the leaf canopy. Moderate to high levels of timber extraction would thus not only affect canopy density and leaf area but would also have a negative influence on the fine root system and its belowground carbon storage capacity.

Heavy disturbance or near-complete destruction of tropical forests, as occurs with the establishment of agroforest systems under cover trees or in tree plantations, can also lead to substantial reductions in $\mathrm{FRB}_{\text {tot }}$, as is evidenced by our data and the literature reports cited below. Sundarapandian et al. (1999) found a significantly larger fine root biomass in tropical natural forests than in nearby rubber, Albizia or Acacia plantations. Only in teak plantations, no decrease in $\mathrm{FRB}_{\text {tot }}$ was found compared to nearby forest. We speculate that canopy 
cover (or leaf area index) might also be a key factor in this type of disturbance determining the extent of root biomass reduction when converting natural forest to woody plantations.

Reductions in $\mathrm{FRB}_{\text {tot }}$ as they are occurring in logging gaps or after conversion to agroforest systems could also be driven by altered microclimatic and edaphic conditions in the clearings. In our stands, elevated light transmission to the forest floor in disturbed forests increased daytime temperatures in the topsoil of gaps by 2 to $3{ }^{\circ} \mathrm{C}$ (data not shown); this could have stimulated fine root growth and activity. On the other hand, gaps showed lower night-time temperatures which should have reduced root respiration. Altered temperature regimes may also influence root growth by increasing nutrient availability in the gaps (in particular plant-extractable P, Denslow et al., 1998), although aboveground litterfall typically decreases in gaps. Finally, root dieback and subsequent mineralization pulses in the topsoil due to root decomposition may temporarily have increased nutrient availability in the stands B, C and D. Short-term increases in nutrient supply immediately after gap formation were indeed observed in tropical forests (Denslow et al., 1998).

However, none of the above-discussed changes in soil physical and chemical parameters, which might have stimulated root growth in the disturbed forests, seem to have influenced $\mathrm{FRB}_{\text {tot }}$ in the forest gaps in the long run in our study, since average $\mathrm{FRB}_{\text {tot }}$ values decreased, and not increased, with growing disturbance intensity. The assumption that disturbancedriven changes in the soil physical and chemical parameters must have exerted only minor influences on $\mathrm{FRB}_{\text {tot }}$ in the Sulawesi stands is further supported by comparable vertical fine root distribution patterns in the soil profiles of all four forest use types. This similarity existed despite the fact that temperature, moisture and nutrient supply are known to be key factors controlling the depth distribution of fine roots in soils (Fitter, 1996; Sainju and Good, 1993).

We conclude that the widespread practise of selective logging and conversion to agroforest systems under tree cover leads to a substantial reduction of fine root biomass in the remaining tropical forests. Disturbed forest may contain only $60 \%$ or less of $\mathrm{FRB}_{\text {tot }}$ as compared to the global average of fine root biomass in undisturbed tropical moist forests. This implies not only lowered average nutrient and water uptake rates in disturbed forests but also reduced carbon storage by the fine root system. The latter effect may seem to be of minor importance when considering the large $C$ losses associated with stem harvesting. However, fine roots typically consume a large fraction of the annual carbon gain of trees (Lauenroth and Gill 2003) which highlights the outstanding role of fine root growth and turnover in the carbon cycling of forests. Additional studies on fine root production and mortality in logged forests are needed in order to better understand the consequences of forest disturbance for the root-growth-related carbon sink in tropical forests. 


\section{Acknowledgements}

This study is part of the German-Indonesian collaborative research project STORMA (Sonderforschungsbereich 552: 'Stability of Rain Forest Margins in Indonesia', subproject C4) funded by the German Research Council (DFG). The financial support is gratefully acknowledged. We thank the inhabitants of Toro village for their hospitality and our local aides for their support during the field work. The stand structural data were supplied by Johannes Dietz, those on soil chemistry by Volker Häring; this is gratefully acknowledged. We also thank Karsten Wesche (University of Halle-Wittenberg) for advice with multivariate statistical analyses.

\section{References}

Achard F., Eva H.D., Stibig H.J. et al., 2002. Determination of deforestation rates of the world's humid tropical forests. Science 297, 999-1002.

Arunachalam A., Pandey H.N., Tripathi R.S. and Maithani K., 1996. Fine root decomposition and nutrient mineralization pattern in a subtropical humid forest following tree cutting. For. Ecol. Manage. 86, 141-150.

Bauhus J., Bartsch N. 1996 Fine-root growth in beech (Fagus sylvatica) forest gaps. Can. J. For. Res. 26, 2153-2159.

Collins N.M., Sayer J.A., Whitmore T.C., 1991. The Conservation Atlas of Tropical forests. Asia and the Pacific. Macmillan Press, London.

Denslow J.S., Ellison A.M., Sanford R.E., 1998. Treefall gap size effects on above-and below-ground processes in a tropical wet forest. J. Ecol. 86, 597-609.

Fitter A., 1996. Characteristics and functions of root systems. In Plant roots: the hidden half. Eds. Y. Waisel, A. Eshel and U. Kafkafi. pp. 1-20. Dekker, New York.

FWI/GFW, 2002. The State of the Forest: Indonesia. Bogor, Indonesia. Forest Watch Indonesia, and Washington, DC. Global Forest Watch.

Gale M.R., Grigal D.F., 1987. Vertical root distributions of northern tree species in relation to successional status. Can. J. For. Res. 17, 829-834.

Herbert D.A., Fownes J.H., Vitousek P.M., 1999. Hurricane damage to a Hawaiian forest: Nutrient supply rate affects resistance and resilience Ecology 80, 908-920.

Hertel D., 1999. Das Feinwurzelsystem von Rein- und Mischbeständen der Rotbuche: Struktur, Dynamik und interspezifische Konkurrenz. Dissertationes Botanicae 317 pp. 206.

Hertel D., Leuschner Ch., 2002. A comparison of four different fine root production estimates with ecosystem carbon balance data in a Fagus-Quercus mixed forest. Plant Soil 239, 237-251.

Hertel D., Leuschner Ch., 2005. Fine root mass and fine root production in tropical moist forests as dependent on soil, climate and elevation. In Mountains in the mist: Science for conserving and managing tropical montane cloud forests. Eds. L.A. Bruijnzeel and J. Juvik. Hawaii Univ. Press. (in press).

Jackson R.B., Canadell J., Ehleringer J.R., Mooney H.A., Sala O.E., Schulze E.D., 1996. A global analysis of root distribution for terrestrial biomes. Oecologia 108, 389-411.

Lauenroth W.K., Gill R., 2003 Turnover of root systems. In Root Ecology. Eds. H. de Kroon and E.J.W. Visser. Springer. Berlin. Pp 61-90.

Leuschner Ch., Hertel D., 2002. Fine root biomass of temperate forests in relation to soil 
acidity and fertility, climate, age and species. Progr. Bot. 64, 405-438.

Leuschner Ch., Hertel D., Coners H., Büttner V., 2001. Root competition between beech and oak: a hypothesis. Oecologia 126, 276-284.

Ostertag R 1998 Belowground effects of canopy gaps in a tropical wet forest Ecology 79, 1294-1304.

Parrota J.A., Lodge D.J., 1991. Fine root dynamics in subtropical wet forest following hurricane disturbance in Puerto Rico. Biotropica 23, 343-347.

Persson H., 1978. Root dynamics in a young Scots pine stand in Central Sweden. Oikos 30 , 508-519.

Pitopang R., Gradstein S.R., Guhardja E., Setiadi D., Mogea J.P., Kessler M. 2005. Tree diversity in six land use types differing in use intensity in Central Sulawesi, Indonesia. Biotropia (in press).

Sanford R.L. 1989. Fine root biomass under a tropical forest light opening in Costa Rica. J. Trop. Ecol. 5, 251-256.

Sanford R.L., 1990. Fine root biomass under light gap openings in an Amazon rain forest. Oecologia 83, 541-545.

Sainju V.M. and Good R.E. 1993. Vertical root distribution in relation to soil properties in New Jersey pinelands forests. Plant Soil 150, 87-97.

Schelhas J., Greenberg R. 1996. Forest patches in the tropical landscapes. Island press, Washington.

Silver W.L. and Vogt K.A. 1993., Fine root dynamics following single and multiple disturbance in a subtropical wet forest ecosystem. J. Ecol. 81, 729-738.

Sundarapandian S.M., Swamy P.S. 1996. Fine root biomass distribution and productivity patterns under open and closed canopies of tropical forest ecosystems at Kodayar in Western Ghats, South India. For. Ecol. Manage. 86, 181-192.

Sundarapandian S.M., Chandrasekaran S., Swamy P.S. 1999. Variations in fine root biomass and net primary productivity due to conversion of tropical forests into plantations. Trop. Ecol. 40, 305-312.

Uhl C., Buschbacher R., Serrao E.A.S. 1988. Abandoned pasture in eastern Amazonia: Patterns of plant succession. J. Ecol. 76, 663-681.

van Praag H.J., Sougnez-Remy S., Weissen F., Carletti G. 1988. Root tunover in a beech stand of the Belgian Ardennes. Plant Soil 105, 87-103.

Vitousek P.M., Denslow J.S. 1986. Nitrogen and phosphorus availability in treefall gaps of a lowland tropical rain-forest. J. Ecol. 74, 1167-1178.

Vogt K.A., Vogt D.J., Palmiotto P.A., O'Hara J., Asbjornsen H. 1996. Review of root dynamics in forest ecosystems grouped by climate, climatic forest type and species. Plant Soil 198, 159-219.

Wilczynski C.J., Pickett S.T.A. 1993. Fine-root biomass within experimental canopy gaps evidence for a belowground gap. J. Veg. Sci. 4, 571-574. 


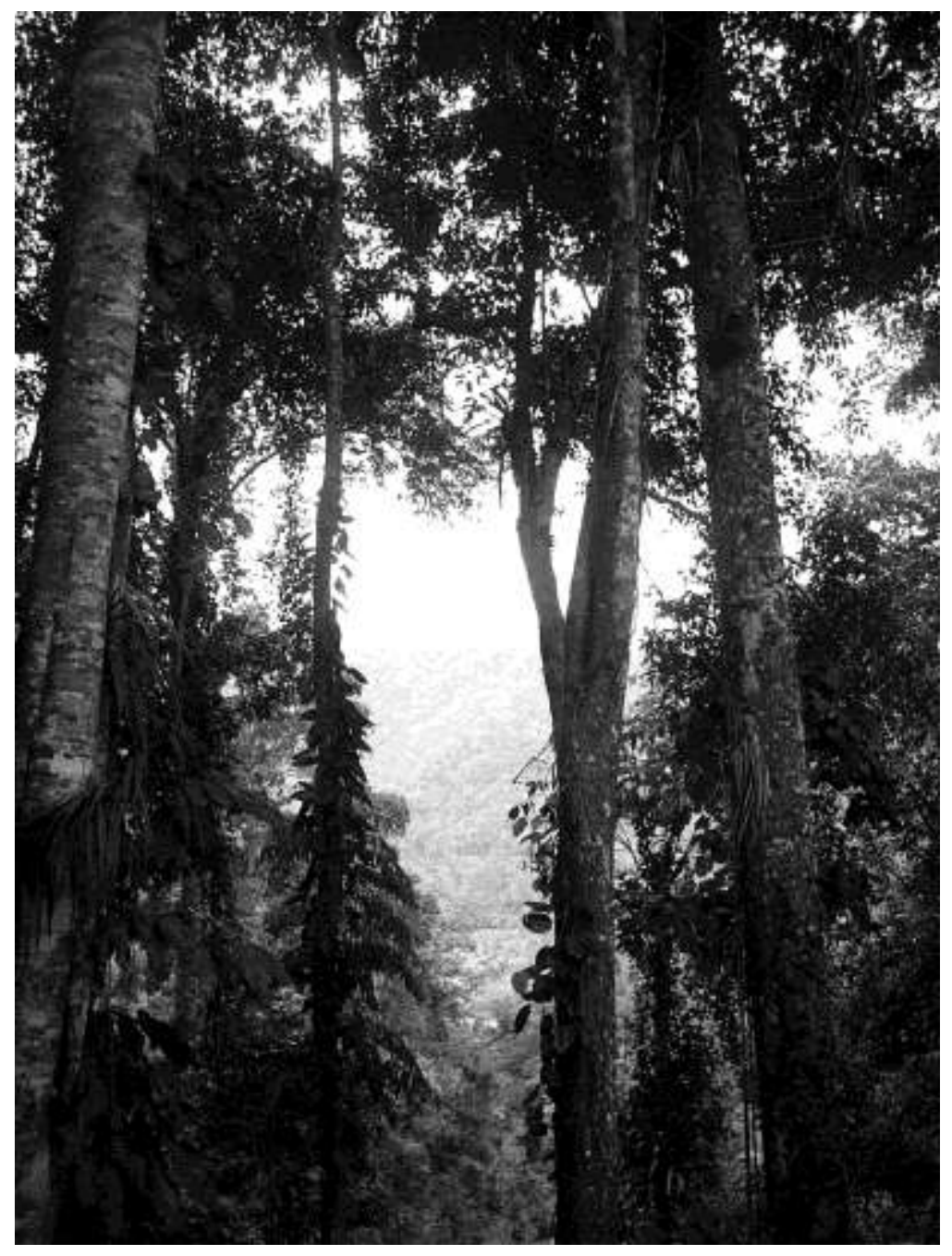


Chapter 3

Spatial and Temporal Variability of Fine Root Abundance and Growth in Tropical Moist Forests and Agroforestry Systems (Sulawesi, Indonesia) 


\begin{abstract}
Selective logging and forest conversion into agroforestry systems are widespread at the margins of tropical moist forests in South-east Asia, typically creating gradients of forest disturbance intensity from the edge to the interior. We studied the effect of increasing forest use on the temporal and spatial variability of fine root mass and fine root production in a submontane tropical moist forest in Central Sulawesi. We selected four forest types which represent a disturbance gradient from undisturbed forest to selectively logged forest with small or large timber extraction, and to agroforestry plantations under natural shade tree cover. Increasing intensity of forest use led to a significant decrease in standing fine root biomass and necromass. Even the extraction of only a limited number of small-diameter stems had a significant negative impact on the amount of fine root biomass. Spatial variability of fine root biomass or necromass within the stands did not differ along the disturbance gradient and neither did the relative seasonal variation in fine root mass. Fine root production was significantly less in the heavily disturbed forest stands than in the undisturbed forest. Fine root biomass and fine root production were strongly correlated with canopy cover and basal area of the stands, whereas soil physical or chemical conditions were of secondary importance. We conclude that mild to moderate disturbances of tropical moist forests have a significant negative effect on total fine root biomass and carbon fluxes associated with root production, whereas spatial and temporal patterns of the fine root system remain largely unaffected.
\end{abstract}

Key words: canopy cover, fine root biomass, fine root necromass, forest disturbance, seasonality, sequential coring. 


\section{Introduction}

In many tropical countries, forest destruction and conversion to agricultural land is continuing at high rates. Indonesia has one of the highest rates of tropical forest loss in the world. Nearly half of Indonesia's forests are fragmented by roads or other access routes, or are encroached by plantations. Forest clearance by small-holder farmers is a significant cause of deforestation. Many protected areas suffer from illegal logging and agricultural encroachment by the local communities. In the margin zones of most Indonesian national parks and forest reserves, rattan (Calamus sp.) extraction, selective logging and the creation of small-scale crop plantations are common activities (FWI/GFW, 2002). Because the area of disturbed forest increases rapidly, we need a better understanding of the ecological consequences of forest disturbance in the aboveground as well as the belowground compartment. Research on the structure and functioning of disturbed tropical forests mostly focuses on aboveground aspects, and the rhizosphere and pedosphere are often ignored. Studies that did focus on belowground effects of forest disturbance in the tropics, mostly dealt with natural disturbances such as hurricanes (Sanford 1989, Parrota \& Lodge 1991, Silver \& Vogt 1993, Denslow et al. 1998, Ostertag 1998). Only recently has the effect of anthropogenic disturbance on the belowground system of tropical forests been studied (Arunachalam et al. 1996, Sundarapandian \& Swamy 1996, Yang et al. 2004, Upadhaya 2005, Leuschner et al. 2006). These studies have mainly focussed on differences in fine root mass, fine root production and the depth distribution of roots, between undisturbed and heavily disturbed forests or planted systems. The objectives of the present study are (1) to investigate the spatial and temporal variability in fine root abundance and fine root production of a tropical sub-montane forest, and (2) to analyze how this variability is affected by mild to moderate forest use intensities and by conversion into agroforestry systems. We hypothesized that increasing forest disturbance enhances the spatial and temporal variation in the fine root system, following changes in canopy structure and tree species composition. A larger heterogeneity of the fine root system is expected to lead to a higher spatial variability of water and nutrient fluxes and carbon sequestration. We further assumed that increasing forest disturbance will reduce the stand average of fine root biomass and associated carbon sequestration through fine root production.

\section{Methods}

\section{Study area}

The Lore Lindu National Park, with a size of approximately 229,000 ha, comprises one of the largest remaining montane rain forests of Sulawesi. We conducted our study in the surroundings of Toro village (Kulawi valley) in the western margin zone of the Lore Lindu Park $\left(01^{\circ} 30^{\prime} \mathrm{S}, 120^{\circ} 02^{\prime} \mathrm{E}\right)$. Annual mean air temperature in the Toro area is about $23^{\circ} \mathrm{C}(\mathrm{H}$. 
Kreilein, unpublished data). With an annual mean of $2200 \mathrm{~mm}$, rainfall generally shows a low seasonality, but dryer or wetter periods may occur due to irregular ENSO (EI Niño Southern Oscillation) effects. In 2004 there was an unusual dry period from June to August. In these months the rainfall was only $73 \mathrm{~mm} \mathrm{mo}^{-1}$, while the average monthly rainfall that year was $143 \mathrm{~mm}$. The natural forest vegetation in the surroundings of Toro is classified as relatively species-rich, lower montane, evergreen, tropical moist forest (Pitopang et al. 2006). The selected stands are located on moderately steep slopes (17-39 $)$ at elevations between 832 and $1130 \mathrm{~m}$ a.s.l. The soil types of the investigated stands are generally well-drained nutrient rich Cambisols (WRB classification); however, under forest use type $C$ the soils had a somewhat lower nutrient availability (Häring et al. 2005, Table 1).

Table 1 Structural characteristics of the four studied forest use types (mean \pm 1 SE; Forest use type A $=$ undisturbed natural forest, type $B=$ natural forest with small timber extraction, type $C=$ natural forest with large timber extraction and type $D=$ cacao plantation under natural shading trees). The soil parameters refer to the topsoil $(0-10 \mathrm{~cm})$. Canopy cover measurements were done with a convex spherical densiometer at 10 randomly selected locations per stand, with 4 readings per location in 4 different directions (N, E, S, W; $n=40$ per stand). ${ }^{1}=$ data from Dietz et al. $2006 .{ }^{2}=$ data from Häring et al. 2005.

\begin{tabular}{|c|c|c|c|c|}
\hline Forest use type & $\mathbf{A}$ & B & C & $\mathbf{D}$ \\
\hline Exposition & SE & SE & SW & $\mathrm{N}$ \\
\hline Mean tree height $(m)^{1}$ & $21.3 \pm 1.1$ & $18.1 \pm 0.9$ & $15.2 \pm 0.9$ & $6.1 \pm 0.3$ \\
\hline Mean dbh $(\mathrm{cm})^{1}$ & $29.5 \pm 1.2$ & $26.9 \pm 1.9$ & $21.3 \pm 9.5$ & $9.5 \pm 0.1$ \\
\hline Stem density $\left(\mathrm{n} \mathrm{ha}^{-1}\right)^{1}$ & $2474 \pm 493$ & $2672 \pm 553$ & $3819 \pm 969$ & $2106 \pm 100$ \\
\hline Total basal area $\left(\mathrm{m}^{2} \mathrm{ha}^{-1}\right)^{1}$ & $52.3 \pm 4.3$ & $47.1 \pm 6.3$ & $39.2 \pm 5.5$ & $21.2 \pm 4.5$ \\
\hline Canopy cover (\%) & $90 \pm 0.3$ & $87 \pm 1.0$ & $82 \pm 0.3$ & $77 \pm 2.5$ \\
\hline Bulk density of the soil $\left(\mathrm{g} \mathrm{cm}^{-3}\right)^{2}$ & $0.99 \pm 0.12$ & $1.11 \pm 0.13$ & $1.08 \pm 0.14$ & $1.20 \pm 0.06$ \\
\hline $\mathrm{pH}(\mathrm{KCl})^{2}$ & $5.07 \pm 0.51$ & $4.69 \pm 0.08$ & $3.87 \pm 0.46$ & $6.05 \pm 0.27$ \\
\hline Base saturation (\%) ${ }^{2}$ & $85.0 \pm 4.5$ & $89.6 \pm 8.4$ & $49.2 \pm 8.4$ & $99.5 \pm 0.2$ \\
\hline Soil N (\%) ${ }^{2}$ & $0.31 \pm 0.05$ & $0.27 \pm 0.07$ & $0.37 \pm 0.18$ & $0.40 \pm 0.06$ \\
\hline Soil C $(\%)^{2}$ & $3.03 \pm 0.62$ & $2.47 \pm 0.62$ & $3.47 \pm 1.31$ & $3.57 \pm 0.42$ \\
\hline
\end{tabular}

This study is part of a comprehensive, multidisciplinary research programme on the stability of rainforest margins (STORMA) and was carried out on shared study sites. Study sites of 30 $\mathrm{m} \times 50 \mathrm{~m}$ were selected representing four typical stages of forest conversion from primary forests to cacao (Theobroma cacao) agroforestry systems in the Lore Lindu region:

- Forest use type A represents an old-growth natural forest which shows only minor traces of human impact. There are no major canopy gaps and the mean overall canopy cover is about 90 \%. Mean tree height and total basal area are highest in this forest type (Table 1). Although there were no signs of timber extraction in forest use type $A$, the extraction of rattan is widespread in all types of forest.

- Forest use type B is a slightly disturbed forest in which small-diameter stems are being selectively extracted at irregular intervals. The canopy cover of this forest type is only a 
few percent less then that of the undisturbed forest, while mean tree height and basal area are markedly lower (Table 1).

- Forest use type C represents a moderately disturbed forest, in which large-diameter stems are selectively logged at irregular intervals. Consequently, small- to medium-size canopy gaps occur. In these canopy gaps, young trees with thin stems form thickets. Still the average overall canopy cover is larger than $80 \%$. The mean tree height and total basal area in this forest use type are lower then in forest types A and B (Table 1).

- Forest use type D is an agroforestry system with cacao, planted under a sparse shading cover of remaining forest trees. This forest type is classified as heavily disturbed and has a much lower mean canopy cover, mean tree height and mean basal area then the other forest use types (Table 1).

Each of these forest use types was replicated three times. Due to different management intensities, the four forest types showed a clear differentiation with respect to canopy cover, $\mathrm{dbh}$ and basal area of the stands (Leuschner et al. 2006), while the species composition of the forest stands remained more or less similar (Pitopang et al. 2006).

\section{Root sampling and root analyses}

To record standing fine root bio- and necromass at the four forest use types we did an inventory on each of the 12 study sites. At six randomly selected sampling locations per study site, root samples were taken with a soil corer $(3.5 \mathrm{~cm}$ in diameter) from the organic layer and the mineral soil down to $50 \mathrm{~cm}$ soil depth. In order to avoid clumping of the sampling locations and to deal with the spatial heterogeneity of the stands, all sampling locations were at least four meters apart. Each of the soil cores was divided into vertically distributed sub-samples (0-10, 10-20, 20-30, 30-40, and 40-50 cm depth). In the lab, the samples were soaked in water and cleaned from soil residues using a sieve with a mesh size of $0.25 \mathrm{~mm}$. large root fractions (> $10 \mathrm{~mm}$ in length) were picked out by hand. Only fine roots of trees (roots $<2 \mathrm{~mm}$ in diameter) were included in the analyses. Living (biomass) and dead rootlets (necromass) were distinguished under the stereomicroscope by colour, root elasticity, and the degree of cohesion of cortex, periderm and stele (Leuschner et al. 2001; Persson 1978). Fine root biomass and fine root necromass of each sample were dried at 70 ${ }^{\circ} \mathrm{C}(48 \mathrm{~h})$ and weighed. The data on fine root abundance was expressed per unit area $\left(\mathrm{g} / \mathrm{m}^{2}\right)$.

In order to make an estimation of seasonal changes in fine root mass and fine root productivity, fine root sampling with the sequential coring method (Persson 1978; Vogt and Persson 1991; Fahey and Hughes 1994; Yang et. al. 2004) was carried out from February 2004 until February 2005. Because of the large time requirement for fine root seasonality and production analysis in forests, we had to confine this part of the study to four stands, i.e. one stand per forest use type. The four stands selected for the production study give a good representation of the gradient of forest use intensity in the region and represented average values of standing fine root mass. We sampled five times at a three-monthly interval. 
However, forest use type $C$ was an exception; here we sampled only 4 times (May 2004 February 2005). Due to disturbance of the study site by a natural tree fall, we selected a new stand matching the definition for this particular forest use type.

At each stand we randomly selected 20 sampling locations at a minimum distance of 4 meters. At each sampling location, the distance to the nearest mature tree was measured, to allow for an analysis of the dependence of fine root mass on tree distance. The root samples were taken with a soil corer $(3.5 \mathrm{~cm}$ in diameter) from the first $20 \mathrm{~cm}$ of the soil and divided into two depths (0-10 and 10-20 cm). To prevent effects of the earlier samplings, while at the same time minimizing soil heterogeneity effects, all subsequent samples at the same location were taken at a distance of approximately $30 \mathrm{~cm}$. The soil samples were transported to the lab at the University of Palu, where the stored samples $\left(4^{\circ} \mathrm{C}\right)$ were processed within six weeks. The processing of the roots was done as described above. The fine root fraction $>10 \mathrm{~mm}$ length obtained with this procedure includes the major part of the biomass, but covers only a small amount of the necromass. The fraction of the dead fine roots smaller then $10 \mathrm{~mm}$ length, may account for a large portion of the total necromass (Bauhaus and Bartsch 1996). Therefore, at each sampling date, one third of the samples was additionally subjected to a more detailed analysis of small fine root particles ( $<10 \mathrm{~mm}$ in length), using a method introduced by van Praag et al. (1988) and modified by Hertel (1999). After removal of the larger root particles (> $10 \mathrm{~mm}$ in length), the residue of the sample was spread evenly on a sheet of filter paper $\left(730 \mathrm{~cm}^{2}\right)$, marked with 36 squares. Six of the squares were randomly selected and analysed under the stereomicroscope for even the smallest dead fine root fragments. The mass of small dead root particles was extrapolated to the entire sample by means of the ratio of small dead rootlets to large dead roots (>10 $\mathrm{mm}$ in length) that was established in the sub-sample.

Fine root production was calculated by analysing the sequential coring data with the 'minimum-maximum method' (Persson 1978, McClaugherty et al. 1982). In this approach, the difference between minimum and maximum of total fine root mass (i.e. fine root biomass plus necromass) in the measuring period is calculated and equated with production. In this study, the measuring period lasted from the end of February 2004 until the end of February 2005 (12 months). In principal, we only considered significant differences between seasonal root mass extremes for estimating production. In the case of forest use type $D$, however, we deviated from this condition and calculated the production despite a non-significant difference, because it was unlikely that the fine root production in the cacao plantation was zero. Because of the ongoing discussion about the best way of calculating fine root production, we additionally calculated FRP with the balancing transfer method (Fairley and Alexander 1985) and compared the results. However, this method is known to be vulnerable for statistical mistakes, because it covers even small, not statistically different, seasonal changes in fine root mass (Kurz and Kimmins 1987). The minimum-maximum method, on the other hand, tends to give an underestimation of the FRP (Singh et al. 1984, Lehman and 
Zech 1998, Vogt et al. 1998). Surprisingly we did not find any significant differences in FRP using either the minimum-maximum or the balancing transfer method (Harteveld et al., submitted). Here we will only present the data from the minimum-maximum method, because it has the advantage that the amount of parameters that can cause errors is kept small. Hertel and Leuschner (2002) found in their comparison between four different production estimates, that the sequential coring method in combination with minimummaximum calculation gave one of the most reliable estimation of FRP.

\section{Statistical analyses}

The fine root mass and fine root production data were compared between the forest use types with Kruskal-Wallis single factor analyses of variance, followed by non-parametric Mann-Whitney two-sample U-tests with a $5 \%$ rejection level. These calculations were done with the software package SPSS version 12.01 (SPSS Inc., Chicago, USA).

The dependence of fine root production on canopy cover, mean temperature at the forest floor, mean soil water content, mean tree height, total basal area, mean dbh, bulk density of the soil, base saturation, $\mathrm{pH}$ and the $\mathrm{N}$ and $\mathrm{C}$ contents of the soil, was analysed by singlefactor linear, or non-linear, regression analyses (software package Xact version 8, SciLab, Hamburg, Germany).

\section{Results}

\section{Stand totals and spatial heterogeneity of fine root biomass and necromass}

The mean total fine root biomass (FRB) in the soil profiles $(0-50 \mathrm{~cm})$ gradually declined with increasing forest use intensity. With a mean value of $313 \mathrm{~g} \mathrm{~m}^{-2}$ forest stands with minor timber extraction (type B) had significantly lower profile totals of FRB than the undisturbed forest stand (type A, $408 \mathrm{~g} \mathrm{~m}^{-2}$; Fig. 1). More severe forest disturbance, in the form of large timber extraction (type $\mathrm{C}$ ) or conversion to cacao agroforestry systems (type D), lead to a further reduction in the profile total of FRB (respectively 225 and $229 \mathrm{~g} \mathrm{~m}^{-2}$ ). In all four forest use types, the largest part (75-90 \%) of FRB and FRN was found in the upper $20 \mathrm{~cm}$ of the soil (which includes the organic layer). FRB in the lower profile $(20-50 \mathrm{~cm})$ decreased in a similar way from $A$ to $D$ as did FRB in the upper soil.

Spatial variation of $\mathrm{FRB}$, measured at the sequential coring sites, was moderate in the three forest types A, B and C with coefficients of variance (CV) between 0.27 and 0.33 for the 20 sampling locations per stand. The CV value differed only marginally between these three stands, but was approx. $10 \%$ greater in the cacao agro forestry system (Table 2). For necromass the $\mathrm{CV}$ values were approximately half of those recorded for biomass with the largest spatial heterogeneity again found in the cacao agroforestry system. 


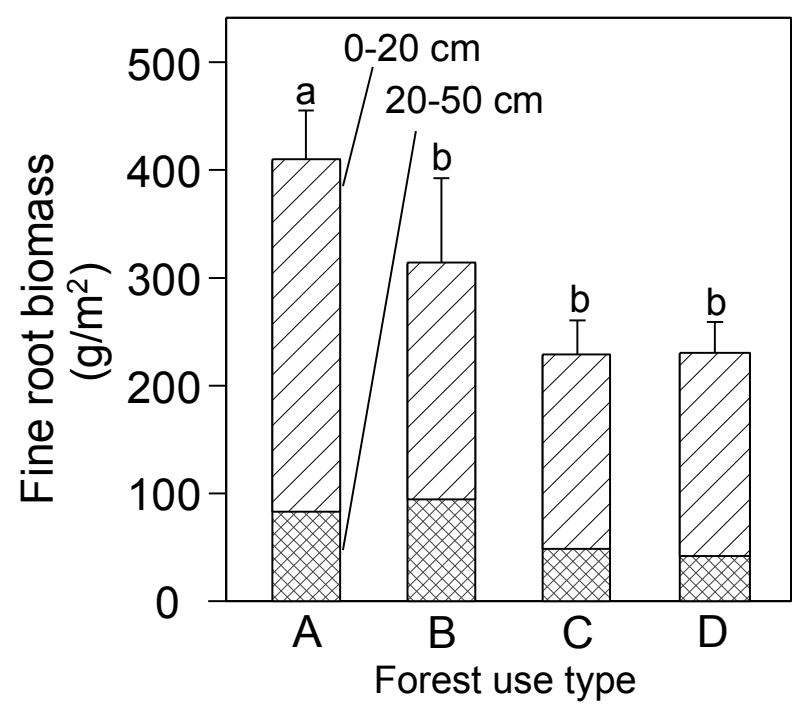

Fig 1 Standing fine root biomass and necromass (mean $+1 \mathrm{SE}$ ) in the four forest use types according to the fine root inventory $(0-50 \mathrm{~cm}$ depth, 3 stands per type, 6 locations per stand). Different letters indicate significant differences between the forest use types at $(p<0.05)$.

Table 2 Coefficients of variance for spatial heterogeneity in mean standing fine root biomass and necromass within the four forest use types ( 1 stand per type, $n=20$ per stand). $F R B=$ fine root biomass, $\mathrm{FRN}=$ fine root necromass.

\begin{tabular}{clc}
\hline $\begin{array}{l}\text { Forest-use } \\
\text { type }\end{array}$ & \multicolumn{2}{l}{ Coefficient of variance } \\
FRB & FRN \\
\hline A & 0.33 & 0.19 \\
B & 0.27 & 0.13 \\
C & 0.29 & 0.15 \\
D & 0.41 & 0.22 \\
\hline
\end{tabular}

Regression analysis of the dependence of fine root density on the distance between sampling location and the nearest tree showed no significant relationship, although distance varied between 0.3 and $4.6 \mathrm{~m}$. This indicates a relatively homogeneous distribution of fine root biomass in the horizontal direction in the four stands (Table 3 ).

Table 3 Correlation coefficients for linear regression analyses of the relation between fine root biomass density and the distance between sampling location and the nearest tree ( 1 stand per type, $n=20$ per stand).

\begin{tabular}{ccc}
\hline $\begin{array}{l}\text { Forest-use } \\
\text { type }\end{array}$ & $\mathrm{r}$ & $\mathrm{p}$ \\
\hline $\mathrm{A}$ & 0.028 & 0.48 \\
$\mathrm{~B}$ & 0.001 & 0.89 \\
$\mathrm{C}$ & 0.005 & 0.78 \\
$\mathrm{D}$ & 0.018 & 0.57 \\
\hline
\end{tabular}


Seasonal variation in fine root bio- and necromass

During the 12-month sampling period, the minimum and maximum values of FRB in a stand differed by factors of 1.2 to 1.5 (Fig. 2). In all stands, the seasonal pattern was more pronounced in the uppermost $10 \mathrm{~cm}$ of the soil than at 10-20 cm depth. The seasonal variation of FRB as averaged over 20 sampling locations was much larger in the forest use types A, B
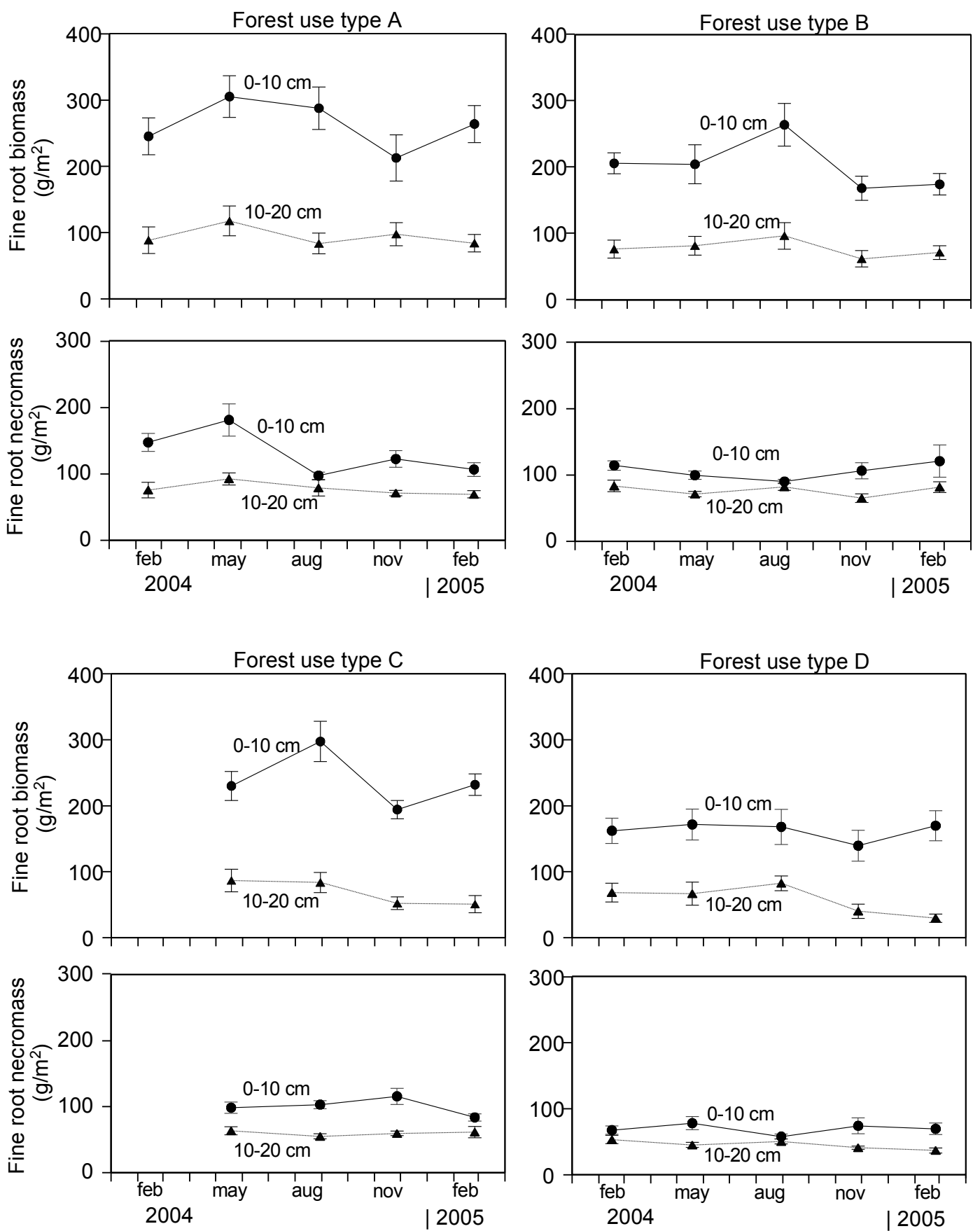
Fig. 2 Seasonal variation in standing fine root biomass and necromass (mean $\pm 1 \mathrm{SE}$ ) at 0-10 cm and $10-20 \mathrm{~cm}$ soil depth in one stand per forest use type A, B, C and D. Given are values of 20 soil samples per stand on 4 or 5 occasions. 
and $\mathrm{C}$ than in the cacao agroforestry system; this was also true for FRN. On the other hand, when considering each of the 20 sampling locations separately, the temporal variation in fine root mass was greater in the cacao agroforest than in the forest use types A, B and C (Table 4).

Table 4 Mean coefficients of variance for the temporal variability of fine root biomass and necromass at 5 consecutive sampling occasions in the four forest use types ( 1 stand per type, $n=20$ per stand). FRB = fine root biomass, $\mathrm{FRN}=$ fine root necromass.

\begin{tabular}{|c|c|c|}
\hline \multirow{2}{*}{$\begin{array}{l}\text { Forest-use } \\
\text { type }\end{array}$} & \multicolumn{2}{|c|}{ Coefficient of variance } \\
\hline & FRB & FRN \\
\hline$A$ & 0.37 & 0.36 \\
\hline B & 0.40 & 0.24 \\
\hline $\mathrm{C}$ & 0.34 & 0.25 \\
\hline$D$ & 0.46 & 0.28 \\
\hline
\end{tabular}

This indicates that while seasonal minima and maxima in the fine root system of the forest types A-C occurred more or less at the same time in each of the sampling locations, the seasonal changes in the cacao agroforestry system did not occur simultaneous. In general, seasonal peaks of FRB were observed from May to August 2004 and minima in November 2004. The fine root biomass maximum coincided with a three-month period of relatively little rainfall (June to August: mean monthly rainfall $73 \mathrm{~mm}$ ), while the minimum was observed at the end of a subsequent wetter period of 3 months (September to November: mean monthly rainfall $152 \mathrm{~mm}$; Table 3). FRB in the three forest use types $A, B$ and $C$ was significantly greater during the drier period than in the following wetter period with average rainfall amounts (Table 5). In contrast, there were no significant differences in overall FRB between the relatively dry and wet periods in the cacao agroforest. Seasonality in fine root necromass was less pronounced than in fine root biomass in all four forest use types (Fig. 2).

Although maxima and minima did not occur synchronously in the four stands, root necromass in the topsoil $(0-20 \mathrm{~cm})$ tended to be less at the end of the relatively dry period (August) than after the wetter period (November, Table 3). However, seasonal differences were not significant for FRN.

Fine root production in its dependence on aboveground forest structure and soil conditions

Annual fine root production (FRP) as calculated from the sequential coring data with the minimum-maximum method varied between $563 \mathrm{~g} \mathrm{~m}^{-2} \mathrm{yr}^{-1}$ in the undisturbed forest and 256 $\mathrm{g} \mathrm{m}^{-2} \mathrm{yr}^{-1}$ in the stand with large timber extraction (Table 6). FRP in the upper $20 \mathrm{~cm}$ of the soil was significantly less in the three disturbed forest use types $(B, C, D)$ than in the 
undisturbed forest (type A). The three disturbed forest types did not differ significantly with respect to fine root production (Table 6). Approximately $60 \%$ of the profile total of annual fine root production took place in the upper $10 \mathrm{~cm}$ of the soil. In all of the studied forest use types it was this uppermost soil horizon that showed the largest differences in root production between undisturbed and disturbed forests.

Table 5 Standing fine root biomass and necromass $(0-10 \mathrm{~cm}$ depth) after a dry period of 3 months (Jun-Aug, 2004) and after the subsequent 3-months rewetting period (Sept-Nov, 2004). In the wet period amounts of rainfall were slightly above the average for $2004\left(143 \mathrm{~mm} \mathrm{mo}{ }^{-1}\right)$. Different letters indicate significant differences between the dry and wet period at $p<0.05$ (Rainfall data from $\mathrm{H}$. Kreilein, pers. obs.). FRB = fine root biomass, FRN = fine root necromass.

\begin{tabular}{lll}
\hline $\begin{array}{l}\text { Forest-use } \\
\text { type }\end{array}$ & $\begin{array}{l}\text { Dry } \\
(73 \mathrm{~mm} / \mathrm{mo})\end{array}$ & $\begin{array}{l}\text { Wet } \\
(152 \mathrm{~mm} / \mathrm{mo})\end{array}$ \\
\hline & $\begin{array}{l}F R\left(\mathrm{~g} / \mathrm{m}^{2}\right) \\
287.6 \pm 32.0 \mathrm{a}\end{array}$ & $212.7 \pm 35.0 \mathrm{~b}$ \\
A & $264.2 \pm 32.1 \mathrm{a}$ & $168.5 \pm 18.2 \mathrm{~b}$ \\
$\mathrm{~B}$ & $297.5 \pm 30.5 \mathrm{a}$ & $194.3 \pm 13.8 \mathrm{~b}$ \\
$\mathrm{C}$ & $167.9 \pm 26.7 \mathrm{a}$ & $139.4 \pm 23.6 \mathrm{a}$ \\
D & $F R N\left(\mathrm{gm}^{2}\right)$ & \\
& $97.4 \pm 5.6 \mathrm{a}$ & $122.5 \pm 12.5 \mathrm{a}$ \\
A & $90.1 \pm 3.3 \mathrm{a}$ & $106.0 \pm 12.1 \mathrm{a}$ \\
B & $103.1 \pm 6.1 \mathrm{a}$ & $115.7 \pm 12.3 \mathrm{a}$ \\
C & $57.8 \pm 3.8 \mathrm{a}$ & $74.1 \pm 11.9 \mathrm{a}$ \\
D &
\end{tabular}

Although the forest use types $A$ and $B$ differed not significantly from each other, the lower soil layer $(10-20 \mathrm{~cm}$ ) showed a similar decrease from $A$ to $D$ as the topsoil; $C$ and $D$ differed significantly from $A$ in this horizon. The seasonal minimum-maximum differences in fine root mass in the 12-month period were significant at a $5 \%$ rejection level in all forest use types except for the cacao plantation (type D).

Regression analysis of fine root production on parameters of aboveground forest structure (canopy cover, mean tree height, total basal area, mean $\mathrm{dbh}$ ) and on edaphic variables (soil bulk density, soil water content, soil surface temperature, base saturation, $\mathrm{pH}(\mathrm{KCl})$, soil $\mathrm{N}$ content) revealed that none of the soil chemical and physical or the climatological factors had a significant effect on fine root productivity (Table 7). In contrast, fine root production showed a positive relationship to above-ground stand structural attributes, i.e. canopy cover, tree height, basal area and dbh. The strongest correlation was found to tree height and basal area of the stands (Table 7, Fig. 3). 
Table 6 Annual fine root production $\left(\mathrm{g} \mathrm{m}^{-2} \mathrm{yr}^{-1}\right)$ in the upper $20 \mathrm{~cm}$ of the soil (including the organic layer) as calculated from the sequential coring data with the minimum-maximum method (mean $\pm 1 \mathrm{SE}$, $n=20$ ). Except for forest use type $D$, only significant differences between minima and maxima of fine root mass were considered. Different Roman letters indicate significant differences between the forest use types at $p<0.05$ and different Greek letters indicate significant differences between the soil horizons at $p<0.05$.

\begin{tabular}{ccccc}
\hline $\begin{array}{l}\text { Forest-use } \\
\text { type }\end{array}$ & $0-10 \mathrm{~cm}$ & $10-20 \mathrm{~cm}$ & $\begin{array}{c}\text { Profile total } \\
0-20 \mathrm{~cm}\end{array}$ \\
\hline A & $353.23 \pm 36.54$ a $\alpha$ & $198.04 \pm 19.57$ a & $\beta$ & $551.27 \pm 48.22 \mathrm{a}$ \\
B & $233.42 \pm 24.82 \mathrm{~b} \alpha$ & $163.22 \pm 22.79$ ab $\beta$ & $396.64 \pm 35.19 \mathrm{~b}$ \\
C & $200.21 \pm 23.35 \mathrm{~b} \alpha$ & $125.52 \pm 15.97$ b & $\beta$ & $325.74 \pm 32.88 \mathrm{~b}$ \\
D & $206.88 \pm 19.42 \mathrm{~b} \alpha$ & $133.56 \pm 16.81 \mathrm{~b}$ & $\beta$ & $340.44 \pm 23.88 \mathrm{~b}$ \\
\hline
\end{tabular}

Table 7 Correlation coefficients for linear or simple exponential $\left(^{*}\right)$ regressions between fine root production and various factors of above-ground forest structure and soil conditions. Significant relationships are printed in bold $(p<0.05)$.

\begin{tabular}{lccr}
\hline Source & $\mathbf{r}$ & $\mathbf{r}^{2}{ }_{\text {adj }}$ & $\mathbf{p}$ \\
\hline Canopy cover * & $\mathbf{0 . 9 0}$ & $\mathbf{0 . 8 8}$ & $\mathbf{0 . 0 4}$ \\
Tree height * & $\mathbf{0 . 9 9}$ & $\mathbf{0 . 9 8}$ & $<\mathbf{0 . 0 1}$ \\
Basal area * & $\mathbf{0 . 9 9}$ & $\mathbf{0 . 9 8}$ & $<0.01$ \\
dbh * & $\mathbf{0 . 9 7}$ & $\mathbf{0 . 9 1}$ & $\mathbf{0 . 0 3}$ \\
Soil surface temperature & 0.52 & -0.09 & 0.48 \\
Soil water content & 0.20 & -0.44 & 0.79 \\
Soil bulk density & 0.77 & 0.41 & 0.22 \\
Base saturation (\%) & 0.07 & -0.49 & 0.92 \\
pH $($ KCl) & 0.20 & -0.44 & 0.79 \\
Soil N & 0.41 & -0.25 & 0.59 \\
\hline
\end{tabular}

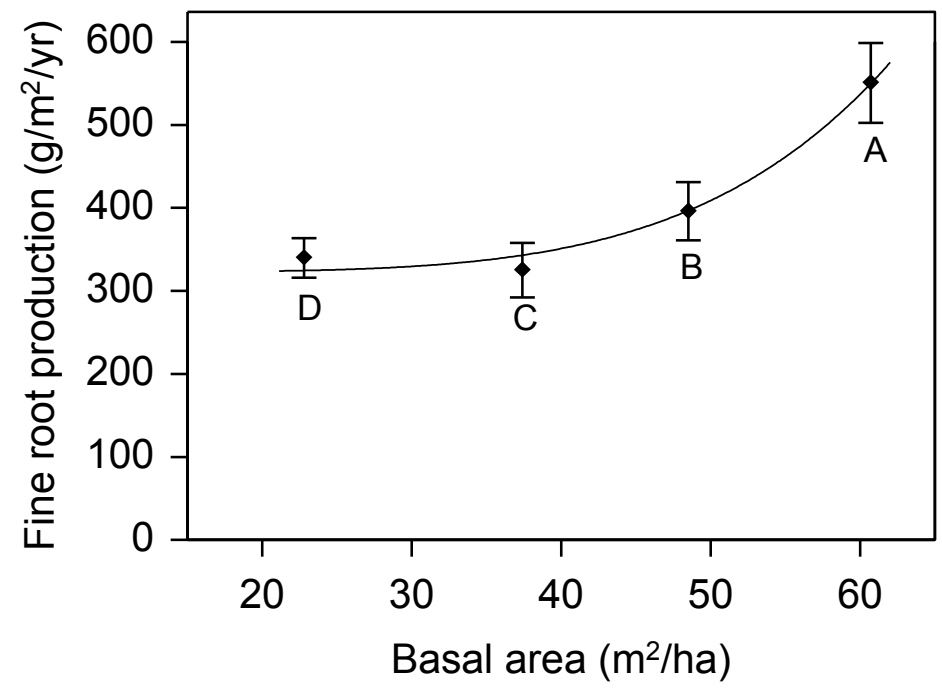

Fig. 3 Relationship between fine root production and basal area of the stands. The different letters indicate the different forest use types. Regression equation: $y=322.8+2.75-0.07 \cdot x^{5}\left(r^{2} a d j=0.99, p<\right.$ 0.01). 


\section{Discussion}

\section{Variability of fine root mass along the disturbance gradient}

Total standing fine root biomass and necromass declined significantly with increasing forest disturbance. Remarkably, even the extraction of small-diameter stems caused a significant reduction in fine root biomass as well as fine root necromass. A similar reduction in FRB due to anthropogenic forest disturbance or conversion from forest to plantation was found in several other studies in (sub)tropical Asia (Sundarapandian \& Swamy 1996, Yang et al. 2004, Upadhaya et al. 2005). In this study, we could also demonstrate a negative effect of forest disturbance on fine root production. A significant decrease in annual fine root production was observed between the undisturbed forest site (forest use type $A$ ) and the three disturbed sites (types B, C and D). Comparable reductions in fine root production were found by Sundarapandian \& Swamy (1996) in a comparison of undisturbed and disturbed tropical moist forests in southern India. However, estimated fine root production in Sulawesi did not decrease in the sequence $B-C-D$ although disturbance intensity increased. This contrasts with differences in FRB and FRN, and also with differences of canopy cover and basal area, which both decreased in this sequence. A possible explanation is that the cacao trees in the agroforestry system, which contribute to FRB in forest use type $D$, have a relatively high fine root production rate but a lower standing FRB than the trees of the natural forest. This idea is supported by greater root regrowth in ingrowth cores in the cacao plantation than in the disturbed forests (Harteveld et al., in prep.).

The observed decrease in FRB and FRN, and also in fine root production, from the undisturbed forest $(A)$ to the disturbed forests could be the result of environmental change with canopy opening or of alterations in the aboveground biomass and structure of the stands. However, in our study the different forest use types did not differ markedly in respect to environmental parameters and therefore no relationship between factors as soil surface temperature, soil water content or soil $\mathrm{C}$ and $\mathrm{N}$ content, and fine root production were observed. In contrast, we observed a strong dependence of fine root mass and production on structural attributes such canopy cover, mean tree height, total basal area, and mean dbh. In a review about the influence of natural and anthropogenic disturbance on the fine root system in tropical moist forests Hertel et al. (2006) found that changes in the above ground structure due to disturbance in all cases lead to a reduction in fine root mass.

\section{Spatial variability of fine root mass within research sites}

Spatial variability of FRB was higher in the shaded cacao agroforest (D) than in the three forest use types A, B and C. This might have been caused by the existence of root gaps, i.e. the local thinning of the root system under canopy gaps (Denslow et al. 1998, Ostertag 1998). However, if this would have been the case, we should have found a negative dependence of FRB on the distance of the sampling location to the nearest tree. Yet, such a 
dependence was not observed in this study. Moreover, the coefficient of variance should have been greater in the disturbed forest use types $B$ and $C$ than in $A$, a pattern we also did not find. Similar to our study, other studies also did not find any relationship between fine root biomass and distance from the nearest tree in temperate or tropical old-growth forests (Hertel 1999, Muñoz \& Beer 2001). We hypothesize that timber extraction and the associated canopy opening did not result in distinct root gaps; rather it may have caused an overall thinning of the root system leading to lowered stand totals of FRB. The observed spatial variability of FRB could also be a result of the spatially highly variable tree species composition in the stands. Thus, in the case of the agroforestry system, the variability may origin from differences in rooting patterns between cacao and the shading trees.

\section{Seasonal variability of fine root mass}

In Central Sulawesi, the maximum FRB was observed at the end of the dry period, and the minimum during the subsequent wet period. This contrasts with observations reported from other regions, e.g. in subtropical China or subtropical and tropical India, where the maximum values of FRB were found in the wet season (Khiewtam et al. 1993, Sundarapandian \& Swamy 1996, Yang et al. 2004, Upadhaya et al. 2005). According to Khiewtam et al. (1993) root biomass peaks may correspond to periods of nutrient release during the wet season. In Sulawesi, there might have been more nutrient release during the dry season than during the wetter period. Woltmann \& Migge-Kleian (unpublished data) found an increase in the decomposing soil fauna during the drier period in our study plots. This could be an explanation for the higher amount of roots at the end of the dry period compared to the wet season. Also, it is known that soil moisture can have a pronounced influence on fine root turnover and productivity. However, whether increase in soil moisture has a positive or a negative effect on fine root turnover seems to differ per location. Some studies report a decrease of fine root turnover with increase in soil moisture (Pregitzer et al. 1993, Hendrick \& Pregitzer 1996), while others state the opposite (Joslin et al. 2000, Jones et al. 2003). The fact that we did not observe an increase in root necromass after root biomass decreased from the dry to the wet season might be explained by rapid decomposition processes in the hot climate of Sulawesi.

Seasonal differences in FRB were more pronounced in the upper $10 \mathrm{~cm}$ of the soil than in the subsurface layer, a finding also reported by two studies in subtropical north-east India (Khiewtam et al. 1993, Upadhaya et al. 2005). Effects of seasonal differences in temperature and rainfall are generally expected to be more distinct in the upper most part of the soil. In the agroforestry system (type D), significant changes in FRB between the drier and the wetter season were not observed. This might be due to the fact that root systems of treebased cropping systems not only respond to seasonal changes of soil moisture and temperature but to tree management activities as well. These tree management activities may mask possible seasonal fine root dynamics (Lehmann 2003). In addition, the production 
of pods could have a negative effect on the fine root production of cacao trees due to competing carbon sinks in the plant (Muñoz \& Beer 2001).

\section{Conclusion}

We conclude from our results that mild to moderate disturbances of tropical moist forests had a significant negative effect on total fine root biomass and carbon fluxes associated with root production. However, in contrast to our hypothesis, spatial and temporal variation in root mass remained largely unaffected by the disturbance regimes.

\section{Acknowledgements}

This study is part of the German-Indonesian collaborative research project STORMA (Sonderforschungsbereich 552: 'Stability of Rain Forest Margins in Indonesia', subproject C4) funded by the German Research Council (DFG). The financial support is gratefully acknowledged. We thank the inhabitants of Toro village for their hospitality and our local aides for their support during the fieldwork.

\section{References}

Arunachalam A., Pandey H.N., Tripathi R.S., Maithani K., 1996. Fine root decomposition and nutrient mineralization patterns in subtropical humid forest following tree cutting. Forest Ecology and Management 86: 141-150.

Bauhus J., Bartsch N., 1996. Fine-root growth in beech (Fagus sylvatica) forest gaps. Canadian Journal of Forest Research-Revue Canadienne de Recherche Forestière 26: 2153-2159.

Denslow J.S., Ellison A.E., Sanford R.E., 1998. Treefall gap size effects on above- and below-ground processes in a tropical wet forest. Journal of Ecology 86: 597-609.

Dietz J., Hölscher D., Leuschner Ch., Malik A., Amir M.A., 2006. Forest structure as influenced by type of community forestry in a lower montane rainforest of Sulawesi, Indonesia. In: Tscharntke, T., Leuschner, Ch., Zeller, M. (eds.) The Stability of Tropical Rainforest Margins: Linking Ecological, Economic and Social Constraints. Springer, Berlin.

Fahey T.J., Hughes J.W., 2004. Fine root dynamics in northern hardwood forest ecosystem, Hubbard Brook Experimental Forest. Journal of Ecology 82: 533-548.

Fairley R.I., Alexander I.J., 1985. Methods of calculating fine root production in forests. In: Fitter A.H., Atkinson D., Read D.J. (eds.) Ecological Interactions in Soil: Plants, Microbes and Animals. pp. 37-42. Blackwell Scientific Publications, Oxford.

FWI/GFW. 2002. The State of the Forest: Indonesia. Bogor, Indonesia. Forest Watch Indonesia and Washington, DC. Global Forest Watch.

Häring V., Köhler S., Gerold G., 2005. Ergebnisse der Bodenkartierung Toro, Nopu (Sulawesi, Indonesien) im Rahmen des SFB552 - Göttingen. p. 40.

Hendrick R.L., Pregitzer K.S., 1996. Temporal and depth-related patterns of fine root dynamics in northern hardwood forests. Journal of Ecology 84: 167-176.

Hertel D. 1999. Das Feinwurzelsystem von Rein- und Mischbeständen der Rotbuche: Struktur, Dynamik und interspezifische Konkurrenz. Dissertationes Botanicae 317. Cramer, Berlin. 
Hertel D., Leuschner Ch., 2002. A comparison of four different fine root production estimates with ecosystem carbon balance data in a Fagus-Quercus mixed forest. Plant and Soil 239: 237-251.

Hertel D., Leuschner Ch., Harteveld M., Wiens M., 2006. Fine root mass, distribution and regeneration in disturbed primary forests and secondary forests of the moist tropics. In: Tscharntke, T., Leuschner, Ch., Zeller, M. (eds.) The Stability of Tropical Rainforest Margins: Linking Ecological, Economic and Social Constraints. Springer, Berlin.

Jones R.H., Mitchell R.J., Stevens G.N., Pecot S. D., 2003. Controls of fine root dynamics across a gradient of gap sizes in a pine woodland. Oecologia 134: 132-143.

Joslin J.D., Wolfe M.H., Hanson P.J., 2000. Effects of altered water regimes on forest root systems. New Phytologist 147: 117-129.

Khiewtam R.S., Ramakrishnan P.S., 1993. Litter and fine root dynamics of a relict sacred grove forest at Cherrapunji in north-eastern India. Forest Ecology and Management 60: 327-344.

Kurz W.A., Kimmins J.P., 1987. Analysis of some sources of error in methods used to determine fine root production in forest ecosystems: a simulation approach. Canadian Journal of Forest Research-Revue Canadienne de Recherche Forestière 17: 909-912.

Lehmann J., Zech W., 1998. Fine root turnover of irrigated hedgerow intercropping in Northern Kenya. Plant and Soil 198: 19-31.

Lehmann J., 2003. Subsoil root activity in tree-based cropping systems. Plant and Soil 255: 319-331.

Leuschner Ch., Hertel D., Coners H., Büttner V., 2001. Root competition between beech and oak: a hypothesis. Oecologia 126: 276-284.

Leuschner Ch., Wiens M., Harteveld M.A., Hertel D., Tjitrosemito S., 2006. Patterns of fine root mass and distribution along a disturbance gradient in a tropical montane forest, Central Sulawesi (Indonesia). Plant and Soil 283: 163-174.

McClaugherty C.A., Aber J.D., Melillo J.M., 1982. The role of fine roots in the organic matter and nitrogen budgets of two forested ecosystems. Ecology 63: 1481-1490.

Muñoz F., Beer J., 2001. Fine root dynamics of shaded cacao plantations in Costa Rica. Agroforestry systems 51: 119-130.

Ostertag R. 1998. Below ground effects of canopy gaps in a tropical wet forest. Ecology 79 : 1294-1304.

Parotta J.A., Lodge D.J., 1991. Fine root dynamics in a subtropical wet forest following hurricane disturbance in Puerto Rico. Biotropica 23: 343-347.

Persson H. 1978. Root dynamics in a young Scots pine stand in Central Sweden. Oikos 30: 508-519.

Pitopang R., Gradstein S.R., Guhardja E., Setiadi D., Mogea J.P., Kessler M., 2006. Tree diversity in six land use types differing in use intensity in Central Sulawesi, Indonesia. Biotropia (in press).

Pregitzer K.S., Hendrick R.L., Fogel R., 1993. The demography of fine roots in response to patches of water and nitrogen. New Phytologist 125: 575-580.

Sanford R.E.1990. Fine root biomass under light gap openings in an Amazon rain forest. Oecologia 83: 541-545.

Singh K.P., Srivastava S.K., Singh R.K., 1984. Analysis of seasonal dynamics and nutrient relations of tree roots in tropical deciduous forests. Final Technical report, U.G.C. Sponsored Research Project. Code 001-Bot.-80, p. 127.

Silver W.L., Vogt K.A., 1993. Fine root dynamics following single and multiple disturbances in a subtropical wet forest ecosystems. Journal of Ecology 81: 729-738. 
Sundarapandian S.M., Swamy P.S., 1996. Fine root biomass distribution and productivity patterns under open and closed canopies of tropical forest ecosystems at Kodayar in Western Ghats, South India. Forest Ecology and Management 86: 181-192.

Upadhaya K., Pandey H.N., Law P.S., Tripathi R.S., 2005. Dynamics of fine and coarse roots and nitrogen mineralization in a humid subtropical forest ecosystem of northeast India. Biology and Fertility of Soils 41: 144-152.

Van Praag H.J., Sougenez-Remy S., Weissen F., Carletti G., 1988. Root turnover in a beech stand of the Belgian Ardennes. Plant and Soil 105: 87-103

Vogt K.A., Persson H., 1991. Measuring growth and development of roots. In: Lassoie, J. P., Hinkley, T. M. (eds.) Techniques and Approaches in Forest Tree Ecophysiology. pp. 447-502. CRC Press, Boca Raton FL.

Vogt K.A., Vogt D.J., Bloomfield J., 1998. Analysis of some direct and indirect methods for estimating root biomass and production. Plant and Soil 200: 71-89.

Yang Y.S., Chen G.S., Lin P., Xie J.S., Guo J.F., 2004. Fine root distribution, seasonal pattern and production in four plantations compared with a natural forest in subtropical China. Annals of Forest Science 61: 617-627. 


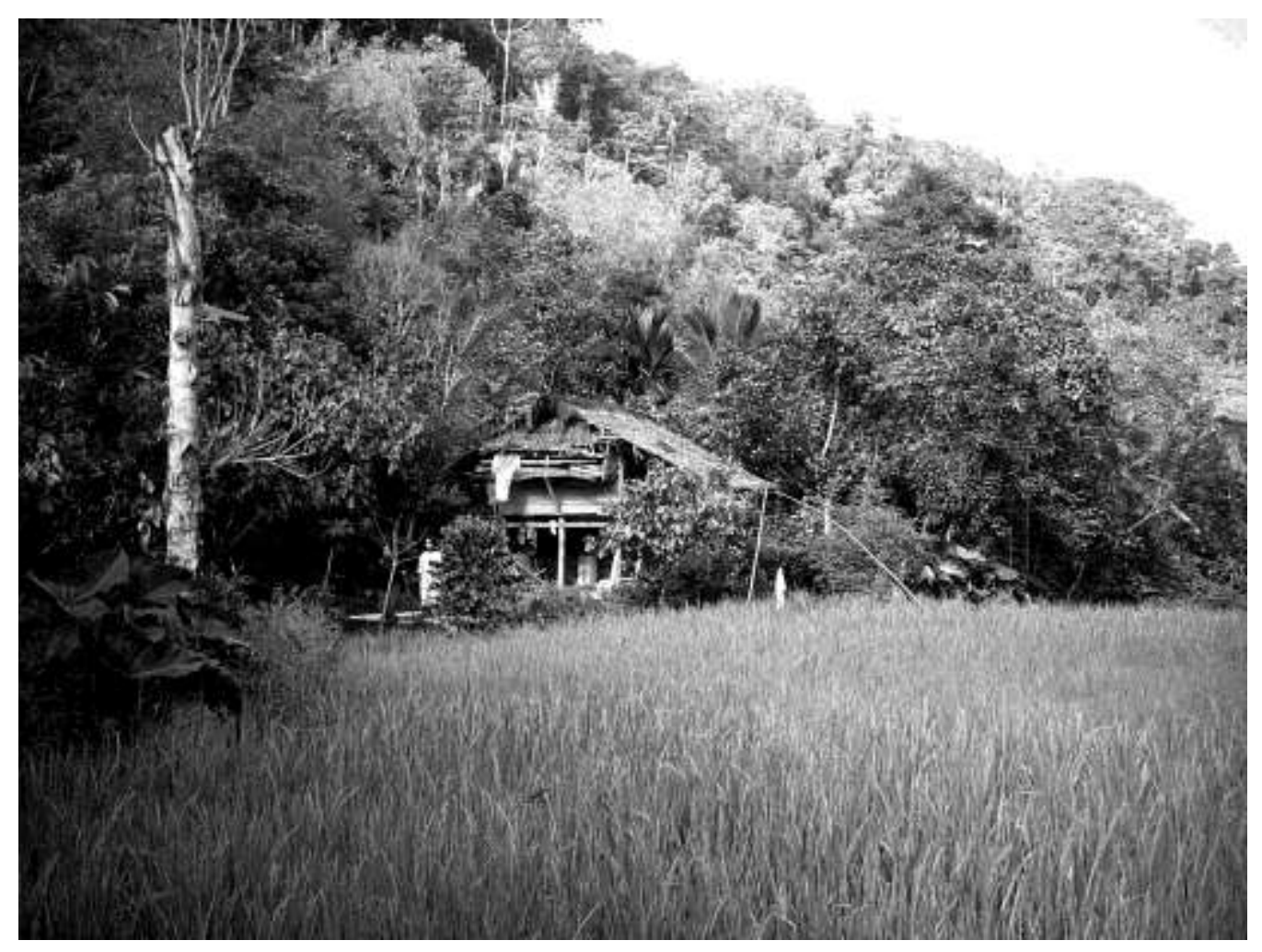




\section{Chapter 4}

Conversion of a tropical forest into agro-forest alters the fine root related carbon sink strength 


\begin{abstract}
Large areas of tropical forests are affected by anthropogenic disturbances of various intensities. These disturbances alter the structure of the forest ecosystem and consequently its carbon budget. We analysed the role of fine root dynamics in the soil carbon budget of tropical moist forests differing in disturbance intensity. Fine root production, fine root turnover, and the associated carbon fluxes from the fine root system to the soil were estimated in five stands ranging from an old-growth forest with negligible anthropogenic disturbance to a cacao agroforestry system with planted shade trees. Annual fine root production and mortality in the three natural forest sites decreased with increasing forest disturbance, with a reduction of more than $45 \%$ between the undisturbed forest site and the site with large timber extraction. However, the agroforestry sites showed intermediate fine root production and mortality values, due to the presence of crop species or the replacement of natural shade tree species by planted shade tree species. The amount of carbon annually added to the soil carbon stock through fine root litter production was highest in the undisturbed forest and decreased with increasing forest use intensity. Only in the plantation with planted shading trees the fine root $C$ flux again reached an intermediate level. However, the relative importance of root $C$ in the total above- and below-ground $C$ input to the soil increased with increasing forest use intensity. We conclude that moderate to heavy disturbance in these tropical moist forests had a profound impact on fine root turnover and the related carbon sink strength of the below-ground compartment.
\end{abstract}

Key words: forest disturbance, fine root production, fine root mortality, carbon sequestration, agroforestry, land use change, root litter. 


\section{Introduction}

Tropical forests are being converted into agricultural land or agroforestry systems at an alarming rate (Nepstad et al. 1999; Achard et al. 2002). In the South-east Asian rainforest region, a variety of low to medium intensity forest use practices are common, including rattan harvest, selective timber extraction and the establishment of small-scale agroforestry systems in the forest margin zone (FWI/GWI, 2002). Forest conversion not only leads to a loss in species diversity (Reiners et al. 1994; Fujisaka et al. 1998; Murdiyarso et al. 2002), but also has a profound effect on the ecosystem's carbon budget (Raich 1983; Lal 2005; Jandl et al. 2006). Changes in forest structure and management practices are likely to alter soil organic carbon content by changed input rates of organic matter, changed decomposability of organic matter and changes in soil moisture and temperature regimes, influencing decomposition rates (Post \& Kwon 2000, Lal 2005). Despite the efforts that have been made to investigate the effects of forest disturbance and forest use intensity on soil carbon stocks (e.g. Raich 1983; Jaramillo et al. 2003; Li et al. 2005; Trumbore et al. 2006), there is still an ongoing debate about whether short-rotation plantations, secondary forests or old-growth forests are more effective in the sequestration of atmospheric $\mathrm{CO}_{2}$. For example, Guo \& Gifford (2002) concluded from a meta-analysis that conversion of forest to tree plantations with broadleaved trees has little effect on soil carbon stocks, whereas planting of conifer trees reduces the soil carbon stock by about $15 \%$. In neo-tropical pastures, Silver et al. (2004) found that maintenance of older reforested sites, as opposed to short-rotation systems, is related to a much higher carbon sequestration in long term carbon pools, in particular in recalcitrant soil organic matter. Correspondingly, Schulze et al. (2000) state that, in contrast to the carbon sink management proposed in the Kyoto protocol, preservation of natural old-growth forests may have a larger effect on carbon sequestration than promotion of forest regrowth. These authors argue that, with increasing life-span of the stand, proportionally more carbon should be transferred into the soil carbon pool with the turnover of leaves and roots. The importance of $C$ input to the soil with the turnover of leaves and roots has e.g. been demonstrated in a study by Powers (2004), where total litter input could explain about $50 \%$ of the observed differences in soil organic carbon concentrations (SOC) between various land-use types in Costa Rica. Still, relatively little is known on the role of fine roots in the $\mathrm{C}$ budget of converted tropical forests.

Allocation of $\mathrm{C}$ to the root system is one of the most important, yet least well quantified fluxes of $C$ in the terrestrial ecosystems (Hendrick \& Pregitzer 1992; Davidson et al. 2002; Matamala et al. 2003). Especially in tropical forests, which are often characterized by rapid fine root turnover, fine root dynamics can contribute significantly to ecosystem carbon fluxes (Silver et al. 2005). Fine root biomass and turnover may even be more important for the accumulation of carbon in forest soils than above-ground litter input (Lugo \& Brown 1993; Block et al. 2006). Below-ground net primary productivity (BNPP) in forests has been estimated at $30-50 \%$ of the total net primary production (Fogel \& Hunt 1979; Keyes \& Grier 
1981; Vogt 1991; Ruess et al. 1996; Xiao et al. 2003). Yet, data on changes in fine root production with conversion of tropical forests are rare (Vogt et al. 1996; Hertel et al. in press). The aim of the present study is to analyse the role of the fine root system in the soil carbon cycle of tropical moist forests differing in disturbance intensity. Based on an analysis of fine root dynamics, we estimated fine root production, fine root turnover and the associated carbon fluxes from the fine root system to the soil in five stages of a gradient in forest use intensity ranging from a near-natural old-growth forest with negligible anthropogenic disturbance to a cacao agroforestry system with planted shade trees representing a high degree of disturbance. We tested the following hypothesis: (1) An increase in forest use intensity will lead to a decrease in fine root productivity and turnover, as mature late-successional trees are supposed to invest more $C$ in the root system, while younger, early successional species, as well as crop species should invest more C in aboveground structures (Tilman 1985; Yan et al. 2006); (2) Fine root related carbon sink strength decreases along the disturbance gradient due to thinning of the stands and lower fine root mortality rates due to a disturbance-driven release from competition.

\section{Study site and methods}

\section{Study area}

This study is part of a comprehensive, multi-disciplinary German-Indonesian research programme on the stability of rainforest margins (STORMA). It was carried out on joint study sites located in the Toro valley, in the margins of the Lore Lindu National Park, Central Sulawesi. Lore Lindu is one of the larger remaining areas of lower-montane evergreen rain forest in the region. In the margin zone of the National Park, gradients of various land use practices with increasing forest disturbance intensity are common. Study sites of $30 \mathrm{~m} \times 50$ $\mathrm{m}$ were selected representing five typical stages of a gradient of forest use intensity from near-natural old growth forests to cacao (Theobroma cacao) agroforestry systems. Each of the forest use types was replicated four times. Selection criteria for the study sites were: good concurrence with the five structurally-defined forest use types, comparability with respect to forest structure among the replicated sites, sufficient spatial homogeneity within the stands and a defined and (temporarily) stable management system. Due to different management intensities, the forest types showed a clear differentiation with respect to canopy cover, diameter at breast height (dbh) and cumulative basal area (Leuschner et al. 2006). Because of the large time requirement for fine root production analysis in forests, we had to confine this study to five stands, i.e. one stand per forest type, which were sampled synchronously. The five sites selected for the present study give a good representation of the gradient of forest use intensity in the region. Data on fine root mass, forest structure and soils are available from all 20 stands (i.e. $5 \times 4$ sites), which gives the opportunity to interpret the root production data in a broader context. The five forest use types are defined as follows: Forest use type $A$ is an old-growth natural forest, with virtually no human impact. 
The overall canopy cover is about $90 \%$ and includes no major gaps. The mean tree height is $21 \mathrm{~m}$ and the total basal area of this stand is about $60 \mathrm{~m}^{2} \mathrm{ha}^{-1}$ (Table 1).

Forest use type $B$ is a slightly disturbed forest from which small timber is selectively extracted at irregular intervals. This forest type has a distinctly lower total basal area (48.5 $\%)$ compared to the undisturbed forest, but its canopy cover remains high (86 \%).

Table 1 Structural characteristics of the five studied stands varying in forest use intensity (Forest use type $A=$ undisturbed natural forest, type $B=$ natural forest with small timber extraction, type $C=$ natural forest with large timber extraction, type $D=$ cacao plantation under natural shading trees and type $E=$ cacao plantation under planted shading trees). The values for maximum tree height are the mean of the $10 \%$ tallest trees. The soil parameters refer to the upper $20 \mathrm{~cm}$ of the soil, with exception of the soil water content which was measured for the upper $6 \mathrm{~cm}$. Canopy cover measurements were done with a convex spherical densiometer at 10 randomly selected locations per stand, with 4 readings per location in 4 different directions (N, E, S, W; $n=40$ per stand). ${ }^{1}=$ data of $\mathrm{J}$. Dietz, $2005 .^{2}=$ data of $\mathrm{L}$. Woltmann, pers.com. ${ }^{3}=$ data from V. Häring et al. 2005.

\begin{tabular}{|c|c|c|c|c|c|}
\hline Forest use type & A & $\mathrm{B}$ & C & $\mathrm{D}$ & $\mathrm{E}$ \\
\hline Exposition & SE & W & $E$ & $\mathrm{~N}$ & W \\
\hline Max tree height $(m)^{1}$ & 42.9 & 35.1 & 33.2 & 35.7 & 14.1 \\
\hline Mean tree height $(m)^{1}$ & 21.9 & 18.9 & 15.1 & 6.7 & 6.2 \\
\hline Mean dbh $(\mathrm{cm})^{1}$ & 30.3 & 27.9 & 20.4 & 9.4 & 6.8 \\
\hline Stem density $\left(\mathrm{n} \mathrm{ha}^{-1}\right)^{1}$ & 2213 & 1933 & 5420 & 2198 & 3660 \\
\hline Basal area $\left(\mathrm{m}^{2} \mathrm{ha}^{-1}\right)^{1}$ & 60.7 & 48.5 & 37.4 & 22.8 & 32.5 \\
\hline Canopy cover (\%) & 90 & 86 & 82 & 72 & 70 \\
\hline Mean temperature at soil surface $\left({ }^{\circ} \mathrm{C}\right)^{2}$ & 20.8 & 20.7 & 21.0 & 22.2 & 22.6 \\
\hline Mean soil water content $(\%)^{2}$ & 35.3 & 33.4 & 37.8 & 28.6 & 30.4 \\
\hline Bulk density of the soil $\left(\mathrm{g} \mathrm{cm}^{-3}\right)^{3}$ & 1.1 & 1.2 & 1.2 & 1.4 & 1.2 \\
\hline $\mathrm{pH}(\mathrm{KCl})^{3}$ & 3.8 & 5.4 & 3.5 & 4.1 & 3.8 \\
\hline Base saturation (\%) ${ }^{3}$ & 84.2 & 98.5 & 49.1 & 74.6 & 38.3 \\
\hline Soil N (\%) ${ }^{2}$ & 0.3 & 0.3 & 0.2 & 0.1 & 0.2 \\
\hline Soil C (\%) ${ }^{2}$ & 2.4 & 2.3 & 2.5 & 1.3 & 1.9 \\
\hline
\end{tabular}


Forest use type $\mathrm{C}$ represents a moderately disturbed forest. Here selective logging of largediameter stems takes place at irregular intervals. As a consequence, small- to medium-size canopy gaps occur, in which young trees form thickets. The canopy cover of this site is relatively high $(82 \%)$, even though the mean tree height $(15 \mathrm{~m})$ and total basal area $\left(37 \mathrm{~m}^{2}\right.$ $\mathrm{ha}^{-1}$ ) are markedly lower than in the undisturbed site. Forest use type $D$ is a 10-year-old agroforestry system with cacao (Theobroma cacao) planted under a sparse shading cover of remaining forest trees and is classified as heavily disturbed. This forest type has a total canopy cover of circa $70 \%$, a mean tree height of $6.7 \mathrm{~m}$ and a basal area of $22.8 \mathrm{~m}^{2} \mathrm{ha}^{-1}$ (Table 1). Forest use type $E$ is a 10 -year-old cacao agroforestry system with planted shade trees (Erythrina subumbran, Glyricidia sepium, Syzigium aromaticum, Nephelium lappaceum). The natural forest vegetation has been completely removed. Canopy cover and mean tree height are similar to those of forest use type D. However, due to more intensive use of the plantation, the total basal area is higher $\left(32.5 \mathrm{~m}^{2} \mathrm{ha}^{-1}\right)$ than in type $D$ where several forest trees remained (Table 1).

The study sites are situated on moderately steep slopes $\left(21-39^{\circ}\right)$ at elevations ranging between 825 and $974 \mathrm{~m}$ a.s.I. The soil type of the five research sites was a well-drained Cambisol (WRB classification). The $\mathrm{pH}(\mathrm{KCl})$ values of the upper mineral soil $(0-20 \mathrm{~cm})$ vary between 3.5 and 5.4, the base saturation between 38 and $99 \%$ (Table 1). The natural forest vegetation in the area is lower montane tropical moist forest in which Castanopsis (Fagaceae), Chionantus (Oleaceae), Dysoxylum (Meliaceae), Ficus (Moraceae) and Lithocarpus (Fagaceae) are widespread genera (Pitopang et al. 2005). The mean air temperature is about $23{ }^{\circ} \mathrm{C}$ and the air humidity ranges mostly between 75 and $90 \%$. With an annual mean of $2200 \mathrm{~mm}$, rainfall generally shows a low seasonality, but dryer or wetter periods may occur due to irregular ENSO (EI Niño Southern Oscillation) effects. In 2004 there was an unusual dry period from June to August. In these months the rainfall was only $73 \mathrm{~mm} \mathrm{mo}^{-1}$, while the average monthly rainfall that year was $143 \mathrm{~mm}$.

\section{Analysis of seasonal fine root dynamics}

In each of the five forest stands we randomly selected 20 sampling locations with a minimum of 4 meters between each location. Fine root standing stock and seasonal changes in fine root mass were investigated using the sequential coring method (Persson 1978; Vogt and Persson 1991). Samples were taken at three-month intervals from February 2004 until February 2005 (5 sampling dates). Forest use type $C$ was an exception; due to disturbance of a former study site by natural tree fall, we changed to another study site and, hence only sampled on 4 occasions. The root samples were taken with a soil corer $(3.5 \mathrm{~cm}$ in diameter) from the upper $20 \mathrm{~cm}$ of the soil, including the organic layer, and sliced into two layers (0-10 and 10-20 cm). To prevent effects of the earlier samplings, while at the same time minimizing soil heterogeneity effects, all subsequent samples at the same location were taken at a distance of approximately $30 \mathrm{~cm}$. The samples were transferred into plastic bags 
and transported to the laboratory in Palu, where they were stored $\left(4^{\circ} \mathrm{C}\right)$ and processed within 6 weeks.

After soaking the root samples in water, they were cleaned from soil residues using a sieve with a mesh size of $0.25 \mathrm{~mm}$. We included only fine roots of trees $(<2 \mathrm{~mm}$ in diameter) in our analyses. Large root particles (>10 mm in length) were picked out by hand. Living and dead root particles were separated under the stereomicroscope by colour, root elasticity and the degree of cohesion of cortex, periderm and stele (Persson 1978; Leuschner et al. 2001). The fine root fraction obtained with this procedure includes the major part of the biomass, but covers only a small amount of the necromass (Bauhus \& Bartsch 1996; Hertel 1999). Therefore, one third of the samples was subjected to an additional, more detailed analysis of small fine root necromass particles ( $<10 \mathrm{~mm}$ length), using a method introduced by van Praag et al. (1988) and modified by Hertel (1999). Fine root biomass and fine root necromass of each sample was dried at $70^{\circ} \mathrm{C}(48 \mathrm{~h})$ and weighed. The data was expressed as fine root abundance (g d.m. $\mathrm{m}^{-2}$ ).

\section{Estimating fine root production and fine root mortality}

Fine root production and fine root mortality were calculated from the sequential coring data with the minimum-maximum method (McClaugherty et al. 1982) and the balancing transfer method (Fairley \& Alexander 1985). Fine root mortality (or fine root loss) is defined here as the transfer of root mass from the biomass to the necromass fraction $\left(\mathrm{g} \mathrm{m}^{-2} \mathrm{yr}^{-1}\right)$, while fine root mortality-rate is fine root mortality per standing fine root biomass $\left(\mathrm{yr}^{-1}\right)$. Fine root turnover is the rate at which the fine roots are being replaced, estimated by dividing annual fine root production by mean standing fine root biomass.

In many cases, the individual sampling locations showed specific seasonality patterns in fine root bio- and necromass that differed from those of other locations. Therefore we estimated fine root production and fine root mortality for each sampling location separately. All calculations were done for the two sampling depths $(0-10,10-20 \mathrm{~cm})$. The minimummaximum method assumes an annual pulse of fine root production. With this method, the fine root production (FRP) is estimated as the difference between the maximum and minimum values of total fine root mass (fine root biomass plus necromass) in the one-yearlong sampling period. For applying the balancing transfer method, we quantified all changes in fine root biomass and necromass for the four sampling intervals separately and used the decision matrix of Fairley \& Alexander (1985) to estimate fine root production and fine root mortality.

In order to have an independent measurement of the fine root growth activity, we additionally conducted an ingrowth-core experiment on replicated study sites, using the method described by Persson (1980), Powell \& Day (1991) and Majdi et al. (1996). This not only 
gave us the opportunity to verify the representativeness of the stands used for the sequential coring, but additionally served as a control for the production estimates obtained with the minimum maximum and balancing transfer method. In order to cover a period of more then one year we installed ingrowth cores from January to July 2004 and from August 2004 until May 2005 in the forest use types A, B, C and D. Due to interference by local people in the more intensively managed and therefore more visited cacao plantations of type $E$ (e.g. by removal of markers or by trampling), it was not possible to include these stands in the ingrowth core experiment. The forest use types A-D were replicated 4 times. Unfortunately, in the first ingrowth period one of the natural forest stands (type A) got destroyed by tree fall and in one of the plantation sites (type D) the markers got removed by local people making it impossible to retrieve the cores. Thus, in the first study period we had three replicas of forest use type $A$ and $D$ and four replicas of forest use type $B$ and $C$. In the second study period all forest use types were replicated four times as planned.

At 10 randomly selected locations per stand, cores were cut from the topsoil (diameter 55 $\mathrm{mm}$, depth $10 \mathrm{~cm}$ ) at a minimum distance of five meter apart from each other. All macroscopically visible live and dead root material was extracted by hand. Smaller dead rootlets were assumed to disappear by decomposition during the experiment. The remaining soil material was replaced into the hole and its edges were marked at the soil surface. Care was taken that the structure and density of the soil samples was conserved as much as possible. No mesh bags were used in order to minimize disturbance effects. The samples were recollected with a soil corer after the respective exposure period. Following Vogt et al. (1998), we then calculated fine root regrowth in the cores as the increase in root biomass from the start of root recolonisation (2 months after installation) until harvest. In the lab, root biomass in the cores was measured as described above. Fine root increment in the cores during the recolonisation period was extrapolated to one year and expressed in $\mathrm{g} \mathrm{m}^{-2} \mathrm{yr}^{-1}$. To get a more balanced estimate of fine root growth during a one year period we took the average of both recolonisation periods. Additionally the data was extrapolated to $20 \mathrm{~cm}$ using the ratio of standing fine root biomass between the two soil layers (Leuschner et al. 2006).

\section{Carbon pools in fine roots and the soil}

The carbon content of tree fine root biomass was established for the two soil depths $(0-10$, $10-20 \mathrm{~cm}$ ) at all sites in February 2005. In the laboratory, the roots were cleaned and extracted as described above. The $\mathrm{C}$ content of the living roots was measured using a $\mathrm{CNH}$ auto-analyser. The stock of $\mathrm{C}$ contained in the standing fine root biomass is termed carbon pool in roots. To estimate the carbon pool in the upper $20 \mathrm{~cm}$ of the soil we used data on the bulk density of the soil and the total soil organic carbon content. The data on total soil organic carbon do not include carbon contained in living fine and coarse roots. The soil organic matter (SOM) is then the sum of the $C$ pool in the soil and the $C$ pool in roots. Data on bulk density and soil organic carbon content of the soil was provided by Häring et al. 
(2005) and L. Woltmann (pers. com.). To estimate the annual flux of carbon to the SOMpool, we multiplied annual fine root mortality with the root $\mathrm{C}$ content.

\section{Statistical analyses}

The data on fine root production and carbon flux from roots to the SOM pool was compared between the five forest use types with one-way Kruskal-Wallis single factor analyses of variance, followed by non-parametric Mann-Whitney two-sample tests with a $5 \%$ rejection level. These calculations were done with the software package SPSS version 12.01 (SPSS Inc., Chicago, USA).

The dependence of fine root production, mortality, mortality-rate, turnover and C flux with fine root loss on various stand structural and edaphic parameters was analysed with single factor linear, or simple non-linear regression analyses (software package Xact version 7.12, SciLab, Hamburg, Germany). 

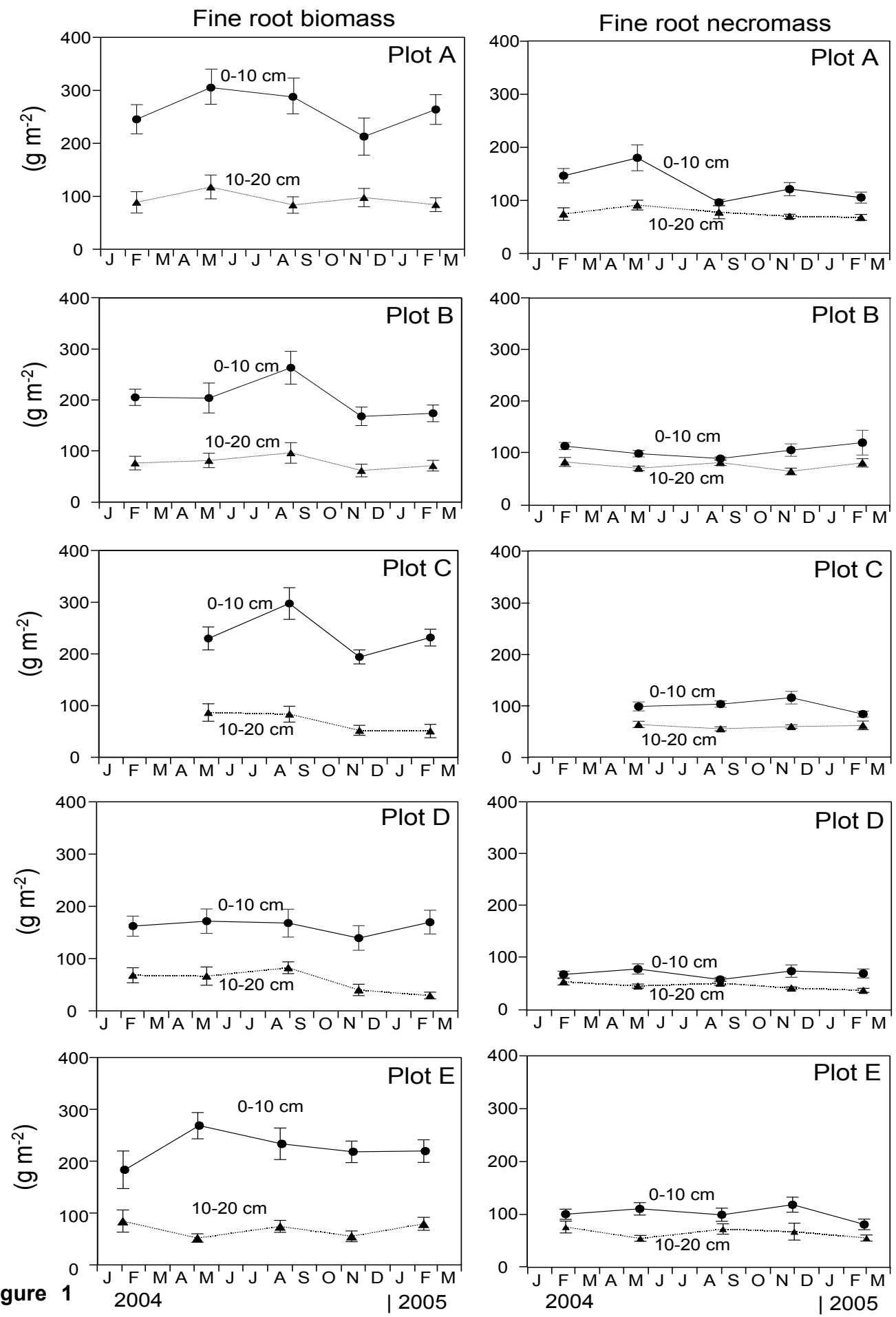

Seasonal variation in standing fine root biomass and necromass (mean $+1 \mathrm{SE}$ ) at 0-10 and 10-20 cm soil depth in the five forest use types A, B, C, D and E. Given are the values of 20 samples per stand at 4 or 5 occasions.

\section{Results}




\section{Seasonal variation of fine root bio- and necromass}

During the 12-month sampling period, the amount of fine root bio- and necromass in the profile up to $20 \mathrm{~cm}$ depth varied by 20 to $50 \%$ around the annual mean (Figure 1). In all five forest use types, the largest seasonal variation in FRB and FRN was found in the upper 10 $\mathrm{cm}$ of the soil, including the organic layer. Further, fine root necromass showed less seasonal variation than fine root biomass. The least seasonal variation in stand averages of bio- and necromass occurred in forest use type $D$ (Figure 1). However, when considering each of the 20 sampling locations separately, forest use type $D$ showed a seasonal variation similar or even higher than in the other forest use types. This is due to the fact that the root mass minima and maxima in stand $D$ occurred less simultaneous than in other plots. The mean annual value of FRB $(0-20 \mathrm{~cm})$ was highest in the undisturbed forest (type A) with $357.1 \mathrm{~g} \mathrm{~m}^{-2}$ and declined towards the cacao plantation under natural shade cover (type $\mathrm{D}$ ) with $219.5 \mathrm{~g} \mathrm{~m}^{-2}$. In the more intensively used cacao plantation (type E), the mean FRB was with a value of $290.1 \mathrm{~g} \mathrm{~m}^{-2}$ similar to that of type $B$ and $C$. Fine root necromass showed a similar pattern among the five stands ranging from $208 \mathrm{~g} \mathrm{~m}^{-2}$ in type $A$ to $114.8 \mathrm{~g} \mathrm{~m}^{-2}$ in type D.

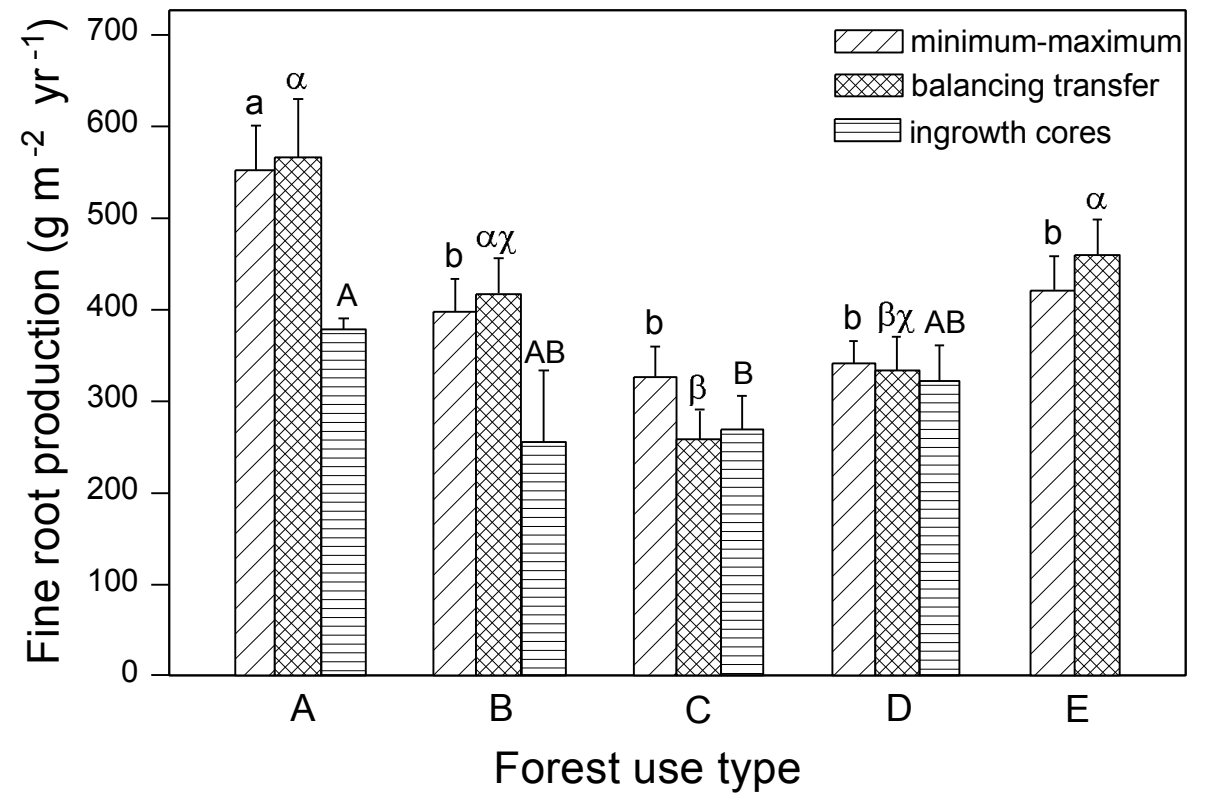

Fig. 2 Fine root production in $\mathrm{g} \mathrm{m}^{-2} \mathrm{yr}^{-1}$ in the five forest types estimated with the minimum-maximum, the balancing transfer method and with ingrowth cores. Different letters indicate significant differences between forest use types at $p<0.05$. Roman letters were used to indicate significant differences found with the minimum-maximum method, Greek letters for those found with the balancing transfer method and capitals for those found with the ingrowth core method. 
The two methods used for calculating annual fine root production from the sequential coring data (minimum-maximum and balancing transfer) resulted in a similar pattern among the stands. There were no significant differences in fine root production estimates between the two calculation methods. The pattern found for fine root production was further confirmed by the production estimates obtained with the ingrowth core method in four stands of the forest use types A-D (Fig. 2). Fine root production in the different forest use types gradually decreased in the order $A>E>B>D>C$, with a fine root production of ca. 550, 450, 400, 330 and $290 \mathrm{~g} \mathrm{~m}^{-2} \mathrm{yr}^{-1}$, respectively. The undisturbed and slightly disturbed stands (type A and B) had a significantly higher fine root production than the stand with large timber extraction (type $\mathrm{C}$ ). On the other hand, the fine root production in the two plantation stands (type $D$ and E) was again higher than that in type $C$, but did not reach the fine root production values measured in the undisturbed natural forest (type A).

The calculation of fine root litter production was done using the balancing transfer method. The balancing transfer method reflects the seasonal changes more accurately than the minimum-maximum method because it considers all variation in fine root mass, while the ingrowth core method can not be used to calculate mortality. Fine root mortality, turnover and mortality-rate showed a similar trend as fine root production (Table 2).

Table 2 Fine root mortality, mortality-rate and turnover (mean $\pm 1 \mathrm{SE}$ ) at $0-10$ and $10-20 \mathrm{~cm}$ soil depth in the five different forest stands. Estimations were made with the balancing transfer method.

\begin{tabular}{|c|c|c|c|c|}
\hline $\begin{array}{l}\text { Forest use } \\
\text { type }\end{array}$ & $\begin{array}{l}\text { Depth } \\
(\mathrm{cm})\end{array}$ & $\begin{array}{l}\text { Fine root } \\
\text { mortality } \\
\left(\mathrm{g} \mathrm{m}^{-2} \mathrm{yr}^{-1}\right)\end{array}$ & $\begin{array}{l}\text { Fine root } \\
\text { mortality-rate } \\
\left(y r^{-1}\right)\end{array}$ & $\begin{array}{l}\text { Fine root } \\
\text { turnover } \\
\left(\mathrm{yr}^{-1}\right)\end{array}$ \\
\hline$A$ & $\begin{array}{r}0-10 \\
10-20\end{array}$ & $\begin{array}{l}347.8 \pm 48.8 \\
201.8 \pm 24.0\end{array}$ & $\begin{array}{l}1.3 \pm 0.2 \\
2.4 \pm 0.3\end{array}$ & $\begin{array}{l}1.5 \pm 0.2 \\
2.6 \pm 0.4\end{array}$ \\
\hline$B$ & $\begin{array}{r}0-10 \\
10-20\end{array}$ & $\begin{array}{l}268.8 \pm 30.5 \\
170.4 \pm 24.0\end{array}$ & $\begin{array}{l}1.4 \pm 0.2 \\
2.2 \pm 0.2\end{array}$ & $\begin{array}{l}1.3 \pm 0.2 \\
2.1 \pm 0.3\end{array}$ \\
\hline C & $\begin{array}{r}0-10 \\
10-20\end{array}$ & $\begin{array}{l}175.4 \pm 23.5 \\
104.6 \pm 15.5\end{array}$ & $\begin{array}{l}0.7 \pm 0.1 \\
2.3 \pm 0.8\end{array}$ & $\begin{array}{l}0.8 \pm 0.1 \\
1.9 \pm 0.7\end{array}$ \\
\hline$D$ & $\begin{array}{r}0-10 \\
10-20\end{array}$ & $\begin{array}{l}222.9 \pm 24.2 \\
139.2 \pm 16.0\end{array}$ & $\begin{array}{l}1.5 \pm 0.1 \\
2.5 \pm 0.2\end{array}$ & $\begin{array}{l}1.5 \pm 0.2 \\
1.4 \pm 0.3\end{array}$ \\
\hline$E$ & $\begin{array}{r}0-10 \\
10-20\end{array}$ & $\begin{array}{l}271.6 \pm 40.1 \\
160.9 \pm 26.4\end{array}$ & $\begin{array}{l}1.2 \pm 0.2 \\
2.4 \pm 0.3\end{array}$ & $\begin{array}{l}1.4 \pm 0.1 \\
2.5 \pm 0.3\end{array}$ \\
\hline
\end{tabular}

Even though standing fine root mass was highest in the upper $10 \mathrm{~cm}$ of the soil, fine root turnover and mortality-rate were, for all types except type D, significantly higher at 10-20 depth than in the upper $10 \mathrm{~cm}$ of the soil. Moreover, the differences in fine root turnover between the forest use types were generally more pronounced at $10-20 \mathrm{~cm}$ depth than in the topsoil. Fine root turnover gradually decreased from $2.6 \mathrm{yr}^{-1}$ in forest use type $\mathrm{A}$ to $1.4 \mathrm{yr}^{-1} \mathrm{in}$ forest type $\mathrm{D}$, followed by an increase to $2.5 \mathrm{yr}^{-1}$ in forest type $\mathrm{E}$. Even though the mortality- 
rate at $10-20 \mathrm{~cm}$ depth did not follow this pattern, we did not find significant differences between turnover and mortality-rate in any of the forest use types, neither at 0-10 nor at 10$20 \mathrm{~cm}$ depth. Fine root turnover and mortality-rate in the upper $10 \mathrm{~cm}$ of the soil were more or less similar in forest use types A, B, D and $E$ where turnover ranged between 1.3 and 1.5 $\mathrm{yr}^{-1}$ and mortality-rate varied between 1.2 and $1.5 \mathrm{yr}^{-1}$. Forest use type $\mathrm{C}$ had a significantly lower turnover $\left(0.8 \mathrm{yr}^{-1}\right)$ and mortality-rate $\left(0.7 \mathrm{yr}^{-1}\right)$ in the upper $10 \mathrm{~cm}$ compared to the other forest use types.

\section{Carbon pools in roots and soil and the $C$ flux from fine root biomass to SOM}

The amount of carbon added annually to the soil by fine root mortality ranged between 10.6 and $19.4 \mathrm{~mol} \mathrm{C} \mathrm{m}^{-2} \mathrm{yr}^{-1}(0-20 \mathrm{~cm})$ and was significantly higher in the undisturbed and slightly disturbed forest stands (type A and B) than in the moderately and heavily disturbed stands (type $C$ and D). However, in the intensively managed agroforestry system with planted shading trees (type E), the carbon flux to the soil through fine root mortality was comparable to that of the slightly disturbed forest site (type B; Table 3).

Table 3 Total soil organic carbon stock and carbon flux with fine root mortality in the upper $20 \mathrm{~cm}$ of the soil. Carbon flux with fine root mortality is given in mol m $\mathrm{mr}^{-1}$ (mean $\pm 1 \mathrm{SE}$ ) and as percentage of the total soil organic carbon stock. Different letters indicate significant differences in the $C$ flux with fine root mortality between the forest use types at $p<0.05$.

\begin{tabular}{cccc}
\hline $\begin{array}{l}\text { Forest use } \\
\text { type }\end{array}$ & $\begin{array}{l}\text { Soil C stock } \\
\left(\mathrm{mol} \mathrm{m}^{-2}\right)\end{array}$ & \multicolumn{2}{c}{$\begin{array}{c}\text { C flux with fine root loss } \\
\left(\mathrm{mol} \mathrm{m}^{-2} \mathrm{yr}^{-1}\right)\end{array}$} \\
\hline A & 425.1 & $19.4 \pm 2.1 \mathrm{a}$ & 4.6 \\
B & 452.5 & $15.8 \pm 1.5 \mathrm{a}$ & 3.5 \\
C & 491.9 & $10.6 \pm 1.0 \mathrm{~b}$ & 2.2 \\
D & 281.2 & $11.5 \pm 0.8 \mathrm{~b}$ & 3.9 \\
E & 365.5 & $15.2 \pm 2.0 \mathrm{ab}$ & 4.2 \\
\hline
\end{tabular}

The carbon input to the soil with fine root mortality accounted for $2.2-4.6 \%$ of the total soil organic carbon stock. A relatively high percentage (> $4 \%$ ) of carbon input through fine root mortality was found in the undisturbed forest as well as in the intensively used agroforestry system. In contrast, the percentage of $\mathrm{C}$ input to the soil $\mathrm{C}$ stock through fine root mortality ranged between 2.2 and 3.9 in the slightly to heavily disturbed forest sites (B-D). The total soil organic carbon stock (excluding the carbon in living fine and coarse roots) in the upper $20 \mathrm{~cm}$ of the soil was on average about $40 \%$ higher in the three forest sites (A-C, $457 \mathrm{~mol}$ $\mathrm{m}^{-2}$ ) compared to that of the two plantation sites ( $\mathrm{D}$ and E, $332 \mathrm{~mol} \mathrm{~m}^{-2}$; Table 3). 


\section{Influence of stand structure and soil chemistry on fine root dynamics and the related $C$ flux}

The results of the regression analyses showed that the response of fine root dynamics and the related carbon flux to variation in the above-ground structure differed between the stands with complete or partial natural tree cover (stands A-D) and the stand with only planted trees (stand E). When only considering the four stands with natural tree cover in the regression analysis, significant correlations $(p<0.05)$ were found between above-ground structural parameters (tree height, total basal area, $\mathrm{dbh}$ ) and fine root production and $\mathrm{C}$ flux to the soil through fine root mortality (Table 4). When including all five forest use types in the analysis, however, almost no significant relationships to stand structural attributes were found (Table 4). Nevertheless, in both cases, some trends $(p<0.1)$ could be identified indicating relationships between fine root mortality and above-ground structural parameters (tree height, total basal area, dbh). No relationships were found between fine root turnover and mortality-rate and any of the above-ground variables. Total basal area of the stands was closely related to forest disturbance intensity; therefore, the positive relation between this structural factor and the carbon flux to the soil through fine root mortality is especially noteworthy (Fig. 3). The edaphic variables did not show any significant correlation with fine root dynamics neither in the four stands with natural tree cover or in the complete dataset with the five stands.

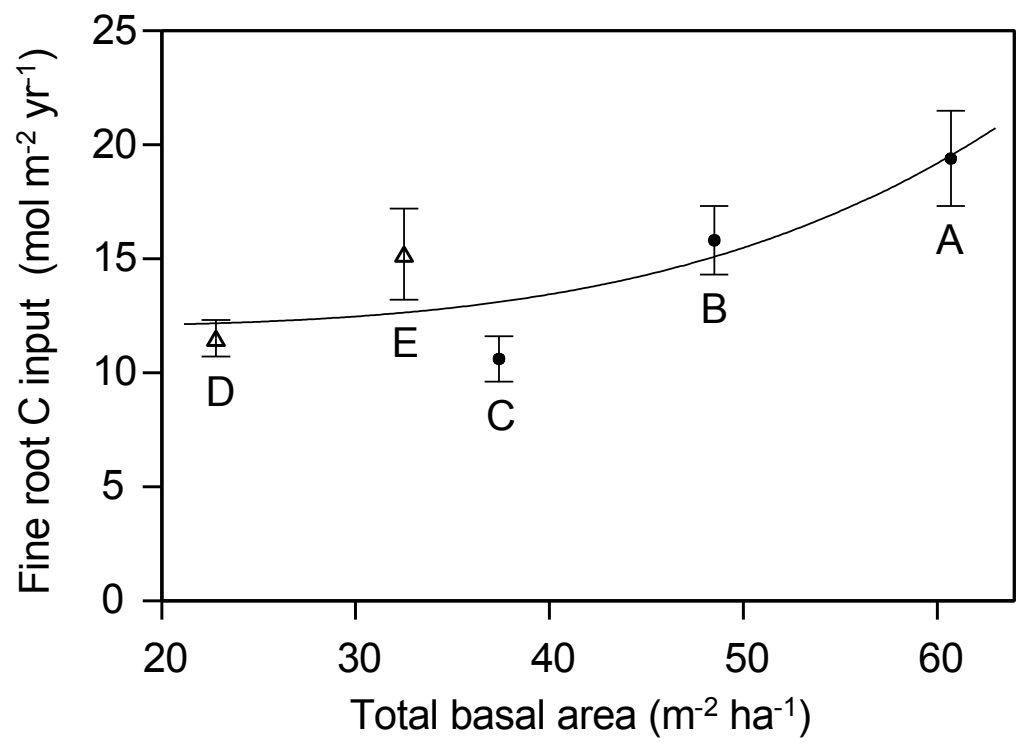

Fig. 3 Relationship between the fine root carbon input to the soil and total basal area of the stands. The different letters stand for the different forest use types. Regression equation: $y=12+5.5-0.07 \cdot x^{4}$ $\left(r^{2}=0.73, p=0.07\right)$. 
Table 4 Correlation coefficients of linear or simple exponential regression of various factors of aboveground forest structure and soil conditions on fine root production, mortality, mortality-rate, turnover and carbon flux for either all five research sites including the plantation with planted shade trees, or for the four stands with natural tree cover $(A-D)$ separately. Significant relationships $(p<0.05)$ are printed in bold.

\begin{tabular}{|c|c|c|c|c|c|}
\hline \multirow[t]{2}{*}{ Parameter } & \multirow[t]{2}{*}{ Source } & \multicolumn{2}{|c|}{ all stands } & \multicolumn{2}{|c|}{ stands A-D only } \\
\hline & & $r^{2}$ & p & $r^{2}$ & $\mathbf{p}$ \\
\hline $\begin{array}{l}\text { Fine root production } \\
\left(\mathrm{g} \mathrm{m}^{-2} \mathrm{yr}^{-1}\right)\end{array}$ & $\begin{array}{l}\text { Canopy cover } \\
\text { Tree height } \\
\text { Basal area } \\
\text { dbh } \\
\text { Soil water content } \\
\text { Soil N } \\
\text { Base saturation } \\
\text { pH }\end{array}$ & $\begin{array}{l}0.35 \\
\mathbf{0 . 7 8} \\
\mathbf{0 . 8 1} \\
0.73 \\
0.02 \\
0.01 \\
0.09 \\
0.02\end{array}$ & $\begin{array}{l}0.29 \\
\mathbf{0 . 0 4} \\
\mathbf{0 . 0 3} \\
0.06 \\
0.80 \\
0.85 \\
0.62 \\
0.81\end{array}$ & $\begin{array}{l}\mathbf{0 . 9 0} \\
\mathbf{0 . 9 9} \\
\mathbf{0 . 9 9} \\
\mathbf{0 . 9 7} \\
0.20 \\
0.41 \\
0.07 \\
0.20\end{array}$ & $\begin{array}{r}\mathbf{0 . 0 4} \\
<0.01 \\
<0.01 \\
\mathbf{0 . 0 3} \\
0.79 \\
0.59 \\
0.92 \\
0.79\end{array}$ \\
\hline $\begin{array}{l}\text { Fine root mortality } \\
\left(\mathrm{g} \mathrm{m}^{-2} \mathrm{yr}^{-1}\right)\end{array}$ & $\begin{array}{l}\text { Canopy cover } \\
\text { Tree height } \\
\text { Basal area } \\
\text { dbh } \\
\text { Soil water content } \\
\text { Soil N } \\
\text { Base saturation } \\
\text { pH }\end{array}$ & $\begin{array}{l}0.40 \\
0.66 \\
0.66 \\
0.69 \\
0.10 \\
0.00 \\
0.21 \\
0.68\end{array}$ & $\begin{array}{l}0.25 \\
0.09 \\
0.09 \\
0.08 \\
0.60 \\
0.98 \\
0.43 \\
0.08\end{array}$ & $\begin{array}{l}0.62 \\
0.84 \\
0.82 \\
\mathbf{0 . 8 9} \\
0.00 \\
0.08 \\
0.56 \\
0.02\end{array}$ & $\begin{array}{l}0.21 \\
0.08 \\
0.09 \\
\mathbf{0 . 0 5} \\
0.94 \\
0.72 \\
0.25 \\
0.86\end{array}$ \\
\hline $\begin{array}{l}\text { Fine root mortality-rate } \\
\left(\mathrm{yr}^{-1}\right)\end{array}$ & $\begin{array}{l}\text { Canopy cover } \\
\text { Tree height } \\
\text { Basal area } \\
\text { dbh } \\
\text { Soil water content } \\
\text { Soil N } \\
\text { Base saturation } \\
\text { pH }\end{array}$ & $\begin{array}{l}0.03 \\
0.08 \\
0.09 \\
0.08 \\
0.67 \\
0.00 \\
0.21 \\
0.69\end{array}$ & $\begin{array}{l}0.76 \\
0.64 \\
0.63 \\
0.65 \\
0.09 \\
0.92 \\
0.43 \\
0.08\end{array}$ & $\begin{array}{l}0.06 \\
0.05 \\
0.07 \\
0.04 \\
0.69 \\
0.14 \\
0.41 \\
0.76\end{array}$ & $\begin{array}{l}0.75 \\
0.75 \\
0.74 \\
0.79 \\
0.17 \\
0.62 \\
0.36 \\
0.13\end{array}$ \\
\hline $\begin{array}{l}\text { Fine root turnover } \\
\left(\mathrm{yr}^{-1}\right)\end{array}$ & $\begin{array}{l}\text { Canopy cover } \\
\text { Tree height } \\
\text { Basal area } \\
\text { dbh } \\
\text { Soil water content } \\
\text { Soil N } \\
\text { Base saturation } \\
\text { pH }\end{array}$ & $\begin{array}{l}0.03 \\
0.22 \\
0.25 \\
0.22 \\
0.23 \\
0.25 \\
0.01 \\
0.00\end{array}$ & $\begin{array}{l}0.77 \\
0.42 \\
0.39 \\
0.43 \\
0.42 \\
0.39 \\
0.84 \\
0.99\end{array}$ & $\begin{array}{l}0.31 \\
0.63 \\
0.62 \\
0.63 \\
0.12 \\
0.18 \\
0.55 \\
0.00\end{array}$ & $\begin{array}{l}0.44 \\
0.21 \\
0.21 \\
0.20 \\
0.65 \\
0.58 \\
0.26 \\
0.99\end{array}$ \\
\hline $\begin{array}{l}\text { Carbon flux with } \\
\text { fine root mortality } \\
\left(\mathrm{mol} \mathrm{m}^{-2} \mathrm{yr}^{-1}\right)\end{array}$ & $\begin{array}{l}\text { Canopy cover } \\
\text { Tree height } \\
\text { Basal area } \\
\text { dbh } \\
\text { Soil water content } \\
\text { Soil N } \\
\text { Base saturation } \\
\text { pH }\end{array}$ & $\begin{array}{l}0.49 \\
0.71 \\
0.73 \\
0.75 \\
0.00 \\
0.03 \\
0.19 \\
0.01\end{array}$ & $\begin{array}{l}0.19 \\
0.07 \\
0.07 \\
0.06 \\
0.93 \\
0.77 \\
0.47 \\
0.88\end{array}$ & $\begin{array}{l}0.81 \\
\mathbf{0 . 9 0} \\
\mathbf{0 . 9 1} \\
\mathbf{0 . 9 1} \\
0.02 \\
0.19 \\
0.49 \\
0.00\end{array}$ & $\begin{array}{l}0.10 \\
\mathbf{0 . 0 4} \\
\mathbf{0 . 0 4} \\
\mathbf{0 . 0 4} \\
0.85 \\
0.57 \\
0.30 \\
0.93\end{array}$ \\
\hline
\end{tabular}




\section{Discussion}

\section{Carbon fluxes to the soil with fine root mortality}

Within the four stands with total or partial cover by forest trees (type A-D) the annual C input to the soil through fine root mortality decreased significantly with increasing disturbance. In the cacao plantation with planted shading trees, on the other hand the $\mathrm{C}$ transfer to the SOC through fine root mortality was comparable to that of the forest site with small timber extraction. This means that for the stands with natural tree cover (forest type A-D) our hypothesis that fine root related carbon sink strength decreases with increasing disturbance due to thinning of the stands and release from competition, could be confirmed: fine root related $\mathrm{C}$ input to the soil in these stands was closely related to stand structure. However, the relatively high $\mathrm{C}$ flux measured in the cacao plantation under planted shading trees was not in line with our hypothesis and indicates that crop species or planted non-forest shade trees not necessarily follow the pattern of early to mid-successional species which allocate proportionally more C above-ground. Silver et al. (2004) made a similar observation in tree plantations in Puerto Rico, where plots dominated by timber species showed relatively high levels of standing fine root biomass. The relatively high $\mathrm{C}$ flux in forest use type $\mathrm{E}$ could also have been related to the relatively young age of the crop and shade trees, which could result in a net increment in fine root mass. However, the amount of fine roots annually lost through root mortality was comparable to the amount of fine roots annually produced, indicating that the system was more or less in a steady state.

Like in our study, conversion of tropical forest often leads to a decrease in SOC as a result of changes in the quality and quantity of the litter input (e.g. Schroth et al. 2002; Hairiah et al. 2006). However, Smith et al. (2002) found that forest conversion to low intensity tree plantations in lowland Amazonia could either lead to a decrease or an increase in SOC. In any case, conversion from tropical forest to agroforestry systems is believed to result in much smaller losses in SOC than conversion into more open cropland (Sanchez 2000; Oelberman et al. 2006).

Since data on $\mathrm{C}$ input via fine root turnover in tropical forests are scarce, we converted the available data on fine root mortality (assuming an average fine root C content of $42 \%$, Jaramillo et al. 2003; Trumbore et al. 2006). From studies in lowland and montane tropical moist forests in Costa Rica and Ecuador and from forests and tree plantations in subtropical China we derived fine root $C$ flux values in the upper $20 \mathrm{~cm}$ of the soil ranging between 9.5 and $30.1 \mathrm{~mol} \mathrm{~m}^{-2} \mathrm{yr}^{-1}$ (Sanford \& Cuevas 1996; Yang et al. 2004; Röderstein et al. 2005). These values are comparable to those found in this study $\left(10.6-19.4 \mathrm{~mol} \mathrm{C} \mathrm{m}^{-2} \mathrm{yr}^{-1}\right)$. The highest $\mathrm{C}$ flux value originated from a natural old growth forest in China, while the lowest of these values originated from a broadleaf tree plantation in the same region. 
To compare $C$ input with fine root mortality to $C$ input with leaf litter fall, we used data of monthly measured above-ground litter fall in the five sequential coring stands and data on carbon content of this litter, provided by an associated project (Woltmann \& Migge-Kleian, unpublished data). This data showed that the carbon input to the soil by above-ground litter production gradually decreased from $45.7 \mathrm{~mol} \mathrm{~m}^{-2} \mathrm{yr}^{-1}$ in the undisturbed natural forest stand (A) to $16.9 \mathrm{~mol} \mathrm{~m}^{-2} \mathrm{yr}^{-1}$ in the plantation under planted shading cover (Table 5). This means that the total $C$ flux to the soil through above- and below-ground litter fall decreased with increasing forest disturbance.

Table 5 Carbon flux with leaf litter fall given in $\mathrm{mol} \mathrm{m}^{-2} \mathrm{yr}^{-1}$ as calculated from data on leaf litter fall and leaf litter carbon content (Woltmann \& Migge-Kleian, unpublished). The sum of $C$ flux with above and below-ground litter fall. And the ratio of $C$ flux with fine root mortality and $C$ flux with leaf litter fall. Different letters indicate significant differences in the $C$ flux with leaf litter fall between the forest use types at $p<0.05$.

\begin{tabular}{cccc}
\hline $\begin{array}{l}\text { Forest-use } \\
\text { type }\end{array}$ & $\begin{array}{l}\text { C-flux with } \\
\text { leaf litter fall } \\
\left(\mathrm{mol} \mathrm{m}^{-2} \mathrm{yr}^{-1}\right)\end{array}$ & $\begin{array}{l}\text { Sum of C-flux with } \\
\text { root and leaf litter } \\
\text { fall }\left(\mathrm{mol} \mathrm{m}^{-2} \mathrm{yr}^{-1}\right)\end{array}$ & $\begin{array}{l}\text { Ratio of } \\
\text { root litter C-flux/ } \\
\text { leaf litter C-flux }\end{array}$ \\
\hline $\mathrm{A}$ & $45.7 \mathrm{a}$ & 65.1 & 0.42 \\
$\mathrm{~B}$ & $31.6 \mathrm{~b}$ & 47.4 & 0.50 \\
$\mathrm{C}$ & $29.1 \mathrm{bc}$ & 39.7 & 0.36 \\
$\mathrm{D}$ & $23.7 \mathrm{c}$ & 35.2 & 0.49 \\
$\mathrm{E}$ & $16.9 \mathrm{~d}$ & 32.1 & 0.90 \\
\hline
\end{tabular}

The leaf litter exceeded fine root litter in the forest stands, but not in the intensively managed agro-forest stand (type E). Thus, the relative importance of the below-ground litter production was larger in forest type $\mathrm{E}$ compared to any of the other forest use types. Our results are in line with the findings of Raich \& Nadelhoffer (1989) that suggest a relative decrease in carbon allocation to roots as leaf litterfall carbon increases. This is very interesting as different tree species apparently not only can have different carbon allocation strategies resulting in different rates of organic carbon input to the soil (Guo et al. 2005), but can also differ in respect to the pathway of carbon input. The significance of below-ground litter input might be even higher considering the fact that root derived $C$ has generally a longer residence time compared to shoot derived $C$ (Rasse et al. 2005). This longer residence time of root $\mathrm{C}$ is due to the higher chemical recalcitrance of root tissue and physical protection through stable aggregates.

\section{Fine root production and turnover}

Our estimates of fine root production and turnover using either the minimum-maximum method or the balancing transfer method were surprisingly similar and did not differ markedly from our ingrowth core results. Other authors comparing different calculation methods for 
estimating fine root production, in most cases, found a larger disagreement between different approaches (e.g. Mäkelä \& Vanninen 2000; Hertel \& Leuschner 2002; Hendricks et al. 2006). In particular, when root biomass and necromass do not distinctly vary within time, the minimum-maximum method may underestimate root production because synchronous events of root formation and root death are partly ignored (Lehmann \& Zech 1998). On the other hand, differences between the two calculation methods are generally small when root growth and death show a clear seasonal pattern, and biomass and necromass maxima and minima differ substantially. Due to distinct differences in rainfall during the study year, the average fine root biomass showed clearly recognizable maxima and minima, with a peak between April and August and a minimum between November and February, with the exception of site $\mathrm{D}$. We probably have detected this subtle biomass seasonality because we did our study with quite a high number (20) of replicate samples per stand. In contrast, fine root necromass generally showed much less seasonality which is thought to be a consequence of high litter decomposition rates.

Overall our annual fine root production estimates $\left(290-550 \mathrm{~g} \mathrm{~m}^{-2} \mathrm{yr}^{-1}\right)$ fall in the middle range of the values reported from other tropical forests $\left(75-1380 \mathrm{~g} \mathrm{~m}^{-2} \mathrm{yr}^{-1}\right.$, Vogt et al. 1996; Hertel et al. 2006). With mean values between 1.3 and $2.0 \mathrm{yr}^{-1}$, our fine root turnover estimates for the upper $20 \mathrm{~cm}$ of the soil can be seen as relatively high in comparison with findings from other tropical studies, where turnover rates between 0.3 and 2.5 have been observed (Ostertag 2001; King et al. 2002; Silver et al. 2005).

Annual fine root production in the three natural forest sites $(A, B, C)$ decreased significantly with increasing forest disturbance. This reduction in fine root production was closely related to a reduction in total basal area, tree height, dbh and canopy cover of the stands as caused by timber extraction (Table 4). A similar influence of stand structure on root productivity has been reported in other studies. For example, Jones et al. (2003) found that overstory density was one of the prime determinants of fine root responses to increasing gap size in subtropical pine woodland. Sundarapandian et al. (1996) observed significantly greater fine root production under closed canopies of evergreen tropical forests compared to more open canopies. In some temperate forests, the average dbh of trees was found to be a good predictor for fine root productivity (Drexhage \& Colin 2001; Le Goff \& Ottorini 2001). This, however, contrasts with our findings that the cacao plantations (sites $D$ and $E$ ) had a lower mean tree height, lower total basal area and lower mean dbh compared to the disturbed forest type $\mathrm{C}$, while having a higher fine root production. Opposite from our hypothesis that early successional species and crop species invest proportionally more $C$ in above-ground structures, our finding might be explained by a relatively high fine root production in the crop species and planted shade tree species in our study sites. It is known that differences in species composition can lead to distinct differences in fine root production (Cuevas et al. 1991). However in the absence of in-depth studies, it can not be decided whether cacao 
trees have a more dynamic fine root system with higher growth rates than the forest trees they are replacing.

Similar to our observations for fine root production, we found a trend of decreasing fine root turnover with increasing disturbance intensity in the three forest sites. However, fine root turnover in the agroforestry systems was comparable with that of the undisturbed and slightly disturbed natural forest stands (Table 2). What factors could cause differences in fine root turnover in the forest stands?

It is known that edaphic factors, e.g. soil nutrient availability, soil acidity, soil water content and soil temperature, can have a profound influence on fine root turnover. For example high nutrient supply rates were found to reduce average root life span and increase turnover, because construction costs of roots are low relative to maintenance costs and uptake rates of young roots are particularly high (Eissenstat et al. 2000; King et al. 2002). At stands with low soil $\mathrm{pH}$ levels often high fine root production rates have been observed (Hertel \& Leuschner in press). Some studies reported an increase in root life span with increasing soil moisture (Pregitzer et al. 1993; Hendrick \& Pregitzer 1996), whereas others found greater fine root turnover at wetter microsites (Joslin et al. 2000; Muñoz \& Beer 2001; Jones et al. 2003). However, in this study none of the above mentioned edaphic parameters varied markedly between the different stands (Table 1). This might explain the lack of correlations between these parameters and fine root turnover (Table 4).

Root competition could have an influence on fine root turnover as well. Where more roots are competing for water and nutrients, the percentage of small-diameter roots is higher. Roots with smaller diameters generally have a faster turnover than fine roots with a bigger diameter (Wells \& Eissenstat 2001). Timber extraction in the natural forest stands leads to a decrease in the total basal area and consequently to a reduction of fine root biomass; this could result in a reduction of root competition at the disturbed sites. In the three natural forest sites (stands $\mathrm{A}-\mathrm{C}$ ) we found a significant positive relationship between fine root turnover and total basal area and mean dbh of the stands (tested with Spearman-rank correlations, $r^{2}=0.99 ; p=0.01$ ). This relationship disappeared when the two agroforestry stands were included in the analysis (Table 4). Although we have no data on competition intensity between the roots in our stands, we assume that the differences in fine root turnover in the forest stands were primarily caused by differences in fine root competition intensity, with a disturbance-driven release from competition leading to a longer average root longevity. As with fine root production, the higher fine root turnover in the cacao plantation might be explained by the differences in species composition. In fact, root turnover has been found to vary greatly among different tree species (Black et al. 1998; Rytter \& Rytter 1998; Matamala et al. 2003).

\section{Conclusion}


In contrast to our hypothesis, our results did not reveal a uniform change in fine root dynamics (i.e. production, turnover and mortality) and the related $\mathrm{C}$ input to the soil as a result of increasing forest disturbance intensity. Fine root production, mortality and $\mathrm{C}$ flux to the soil decreased markedly from the undisturbed forest to the forest with large timber extraction, while the soil $\mathrm{C}$ stock remained more or less unchanged. The two cacao agroforestry types, on the other hand, had markedly lower SOM values, but fine root production, mortality and the related $\mathrm{C}$ input to the soil were significantly larger than in the heavily disturbed forest type. Surprisingly, the relative importance of fine roots in the total above and below ground $\mathrm{C}$ influx to the soil increased clearly from the natural forest towards the agroforestry systems. We conclude from our findings that forest conversion had a profound effect on the fine root related carbon sink strength, even though crop trees and planted shade trees could partly compensate for this effect through a proportionally high fine root related $\mathrm{C}$ input to the soil.

\section{Acknowledgements}

This study is part of the German-Indonesian collaborative research project STORMA (Sonderforschungsbereich 552: 'Stability of Rain Forest Margins in Indonesia', subproject C4) funded by the German Research Foundation (DFG). The financial support is gratefully acknowledged. We thank the inhabitants of Toro village for their hospitality, our local aides for their support during the fieldwork, Lars Woltmann for providing data on litter carbon content and Herman Jungkunst for his helpful comments on this manuscript.

\section{References}

Achard F., Eva H.D., Stibig H.J., Mayaux P., Gallego J., Richards T., Malingreau J.P., 2002. Determination of deforestation rates of the world's humid tropical forests. Science 297: 999-1002.

Bauhus J., Bartsch N., 1996. Fine-root growth in beech (Fagus sylvatica) forest gaps. Canadian Journal of Forest Research-Revue Canadienne de Recherche Forestière 26: 2153-2159.

Black K.E., Harbron C.G., Franklin M., Atkinson D., Hooker J.E., 1998. Differences in root longevity of some tree species. Tree Physiology 18: 259-264.

Block R.M.A., Van Rees K.C.J., Knight J.D., 2006. A review of fine root dynamics in Populus plantations. Agroforestry Systems 76: 73-84.

Cuevas E., Brown S., Lugo A.E., 1991. Above and below-ground organic matter storage and production in a tropical pine plantation and a paired broadleaf secondary forest. Plant and Soil 135: 257-268.

Davidson E.A., Savage K., Bolstad P., Clark D.A., Curtis P.S., Ellsworth D.S., Hanson P.J., Law B.E., Luo Y., Pregitzer K.S., Randolph J.C., Zak D., 2002. Below-ground carbon allocation in forests estimated from litterfall and IRGA-based soil respiration measurements. Agricultural and Forest Meteorology 113: 39-51.

Dietz J., Hölscher D., Leuschner Ch., Malik A., Amir M.A., 2006. Forest structure as influenced by type of community forestry in a lower montane rainforest of Sulawesi, 
Indonesia. In: Tscharntke, T., Leuschner, Ch., Zeller, M. (eds.) The Stability of Tropical Rainforest Margins: Linking Ecological, Economic and Social Constraints. Springer, Berlin.

Drexhage M., Colin F., 2006. Estimating root system biomass from breast-height diameters. Forestry 74: 491-497.

Eissenstat D.M., Wells C.E., Yanai R.D., Whitbeck J.L., 2000. Building roots in a changing environment: implications for root longevity. New Phytologist 147: 33-42.

Fairley R.I., Alexander I.J., 1985. Methods of calculating fine root production in forests. In: Fitter, A.H., Atkinson, D. \& Read, D.J. (eds.) Ecological interactions in soil, plants, microbes and animals. Blackwell Science Publishers, Oxford, pp 37-42.

Fogel R., Hunt G., 1979. Fungal and arboreal biomass in a western Oregon Douglas-fir ecosystem: distribution patterns and turnover. Canadian Journal of Forest ResearchRevue Canadienne de Recherche Forestière 9: 245-256.

Fujisaka S., Escobar G., Veneklaas E., 1998. Plant community diversity relative to human land uses in Amazonian forest colony. Biodiversity and Conservation 7: 41-57.

FWI/GFW, 2002. The State of the Forest: Indonesia. Bogor, Indonesia. Forest Watch Indonesia and Washington, DC. Global Forest Watch.

Guo L.B., Gifford R.M., 2002. Soil carbon stocks and land use change: a meta analysis. Global Change Biology 8: 345-360.

Guo L.B., Halliday M.J., Siakimotu S.J.M., Gifford R.M., 2005. Fine root production and litter input: Its effect on soil carbon. Plant and Soil 272: 1-10.

Hairiah K., Sulistyani H., Suprayogo D., Widianto, Purnomosidhi P., Widodo R.H., Van Noordwijk M., 2006. Litter layer residence time in forest and coffee agroforestry systems in Sumberjaya, West Lampung. Forest Ecology and Management 224: 45-57.

Häring V., Köhler S., Gerold G., 2005. Ergebnisse der Bodenkartierung Toro, Nopu (Sulawesi, Indonesien) im Rahmen des SFB552 - Göttingen. p. 40.

Hendrick R.L., Pregitzer K.S., 1992. The demography of fine roots in a northern hardwood forest. Ecology 73: 1094-1104.

Hendrick R.L., Pregitzer K.S., 1996. Temporal and depth-related patterns of fine root dynamics in northern hardwood forests. Journal of Ecology 84: 167-176.

Hendricks J.J., Hendrick R.L., Wilson C.A., Mitchell R.J., Pecot S.D., Guo D., 2006. Assessing the patterns and controls of fine root dynamics: an empirical test and methodological review. Journal of Ecology 94: 40-57.

Hertel D., 1999 Das Feinwurzelsystem von Rein- und Mischbeständen der Rotbuche: Struktur, Dynamik und interspezifische Konkurrenz. Dissertationes Botanicae 317. Cramer, Berlin.

Hertel D., Leuschner Ch., 2002. A comparison of four different fine root production estimates with ecosystem carbon balance data in a Fagus-Quercus mixed forest. Plant and Soil 239: 237-251.

Hertel D., Hölscher D., Köhler L., Leuschner Ch., 2006. Changes in fine root system size and structure during secondary succession in tropical montane forests of the Cordillera de Talamanca, Costa Rica. In: Kapelle, M. (ed.) Ecology and conservation of Neotropical montane oak forests. Ecological Studies 185, Springer, New York.

Hertel D., Leuschner Ch., Harteveld M., Wiens M., in press. Fine root mass, distribution and regeneration in disturbed primary forests and secondary forests of the moist tropics. In: Tscharntke, T., Leuschner, Ch., Zeller, M. (eds.) The Stability of Tropical Rainforest Margins: Linking Ecological, Economic and Social Constraints. Springer, Berlin.

Hertel D., Leuschner Ch. in press. Fine root mass and fine root production in tropical moist forests as dependent on soil, climate and elevation. In: Bruijnzeel, S., Juvik, J. (eds.) Mountains in the mist: Science for conserving and managing tropical montane cloud forests. Hawaii Univ. Press. 
Jandl R., Lindner M., Vesterdal L., Bauwens B., Baritz R., Hagedorn F., Johnson D.W., Minkkinen K., Byrne K.A., 2006. How strongly can forest management influence soil carbon sequestration? Geoderma, doi:10.1016/j.geoderma.2006.09.003.

Jaramillo V.J., Ahedo-Hemández R., Kauffman J.B., 2003. Root biomass and carbon in a tropical evergreen forest of Mexico: changes with secondary succession and forest conversion to pasture. Journal of Tropical Ecology 19: 457-464.

Jones R.H., Mitchell R.J., Stevens G.N., Pecot S.D., 2003. Controls of fine root dynamics across a gradient of gap sizes in a pine woodland. Oecologia 134: 132-143.

Joslin J.D., Wolfe M.H., Hanson P.J., 2000. Effects of altered water regimes on forest root systems. New Phytologist 147: 117-129.

Keyes M.R., Grier C.C., 1981. Above- and below-ground net production in 40-year-old Douglas-fir stands on low and high productivity sites. Canadian Journal of Forest Research-Revue Canadienne de Recherche Forestière 11: 599-605.

King J.S., Albaugh T.J., Allen H.L., Buford M., Strain B.R., Dougherty P., 2002. Belowground carbon input to soil is controlled by nutrient availability and fine root dynamics in loblolly pine. New Phytologist 154: 389-398.

Lal R., 2005. Forest soils and carbon sequestration. Forest Ecology and Management 220: 242-258.

Le Goff N., Ottorini J.M., 2001. Root biomass and biomass increment in a beech (Fagus sylvatica) stand in North East France. Annals of Forest Science 58: 1-13.

Lehmann J., Zech W., 1998. Fine root turnover of irrigated hedgerow intercropping in Northern Kenya. Plant and Soil 198: 19-31.

Leuschner Ch., Hertel D., Coners H., Büttner V., 2001. Root competition between beech and oak: a hypothesis. Oecologia 126: 276-284.

Leuschner Ch., Wiens M., Harteveld M., Hertel D., 2006. Patterns of fine root mass and distribution along a disturbance gradient in a tropical montane forest, Central Sulawesi. Plant and Soil 283: 163-174.

Li Y., Xu I., Zou X., Shi E., Zhang Y., 2005. Comparing soil organic carbon dynamics in plantation and secondary forest in wet tropics in Puerto Rico. Global Change Biology 11: 239-248.

Lugo A.E., Brown S., 1993. Management of tropical soils as sinks or sources of atmospheric carbon. Plant and Soil 149: 27-41.

Majdi H., Pregitzer K., Morén A.S., Nylund J.E., Ågren G.I., 2005. Measuring fine root turnover in forest ecosystems. Plant and Soil 267: 1-8.

Mäkelä A., Vanninen P., 2000. Estimation of fine root mortality and growth from simple measurements: a method based on system dynamics. Trees 14: 316-323.

Matamala R., Gonzalez-Meler M.A., Jastrow J.D., Norby R.J., Schlesinger W.H., 2003. Impacts of fine root turnover on forest NPP and soil C sequestration potential. Science 302: 1385-1387.

McClaugherty C.A., Aber J.D., Melillo J.M., 1982. The role of fine roots in the organic matter and nitrogen budgets of two forested ecosystems. Ecology 63: 1481-1490.

Muñoz F., Beer J., 2001. Fine root dynamics of shaded cacao plantations in Costa Rica. Agroforestry Systems 51: 119-130.

Murdiyarso D., Van Noordwijk M., Wasrin U.R., Tomich T.P., Gillison A.N., 2002. Environmental benefits and sustainable land use options in the Jambi transect, Sumatra. Journal of Vegetation Science 13: 429-438.

Nepstad D.C., Verissimo A., Alencar A., Nobre C., Lima E., Lefebvre P., Schlesinger P., Potter C., Moutinho P., Mendoza E., Cochrane M., Brooks V., 1999. Large-scale impoverishment of Amazonian forests by logging and fire. Nature 398: 505-508. 
Oelbermann M., Voroney P.R., Kass D.C.L., Schlönvoigt A.M., 2006. Soil carbon and nitrogen dynamics using stable isotopes in 19- and 10-year-old tropical agroforestry systems. Geoderma 130: 356-367.

Ostertag R., 2001. Effect of nitrogen and phosphorus availability on fine-root dynamics in Hawaiian montane forests. Ecology 82: 485-499.

Persson H., 1978. Root dynamics in a young Scots pine stand in Central Sweden. Oikos 30: 508-519.

Persson H., 1980. Fine-root dynamics in a Scots pine stand with and without near optimum nutrient and water regimes. Acta Phytogeogr. Suecica 68: 101-110.

Pitopang R., Gradstein S.R., Guhardja E., Setiadi D., Mogea J.P., Kessler M., in press. Tree diversity in six land use types differing in use intensity in Central Sulawesi, Indonesia. Biotropia.

Post W.M., Kwon K.C., 2000. Soil carbon sequestration and land use change: processes and potential. Global Change Biology 6: 317-327.

Powel S.W., Day F.P., 1991. Root production in four communities in the Great Dismal Swamp. American Journal of Botany 78: 288-297.

Powers J.S. 2004. Changes in soil carbon and nitrogen after contrasting land-use transitions in northern Costa Rica. Ecosystems 7: 134-146.

Pregitzer K.S., Hendrick R.L., Fogel R., 1993. The demography of fine roots in response to patches of water and nitrogen. New Phytologist 125: 575-580.

Raich J.W., 1983. Effects of forest conversion on the carbon budget of a tropical soil. Biotropica 15: 177-184.

Raich J.W., Nadelhoffer K.J., 1989. Below-ground carbon allocation in forest ecosystems: global trends. Ecology 70: 1346-1354.

Rasse D.P., Rumpel C., Dignac M.F., 2005. Is soil carbon mostly root carbon? Mechanisms for a specific stabilisation. Plant and Soil 269: 341-356.

Reiners W.A., Bouwman A.F., Parsons W.F.J., Keller M., 1994. Tropical rain forest conversion to pasture: changes in vegetation and soil properties. Ecological Applications 4: 363-377.

Röderstein M., Hertel D., Leuschner Ch., 2005. Above- and below-ground litter production in three tropical montane forests in southern Ecuador. Journal of Tropical Ecology 21: 483492.

Ruess R.W., Van Cleve K., Yarie J., Viereck L.A., 1996. Contribution of fine root production and turnover to the carbon and nitrogen cycling in taiga forest of the Alaskan interior. Canadian Journal of Forest Research-Revue Canadienne de Recherche Forestière 26: 1326-1336.

Rytter R.M., Rytter L., 1998. Growth, decay, and turnover rates of fine roots of basket willows. Canadian Journal of Forest Research-Revue Canadienne de Recherche Forestière 28: 893-902.

Sanchez P.A., 2000. Linking climate change research with food security and poverty reduction in the tropics. Agriculture Ecosystems and Environment 82: 371-383.

Sanford R.L., Cuevas E., 1996. Root growth and rhizosphere interactions in tropical forests. In: Mulkey, S.S., Chazdon, R.L., Smith, A.P. (eds.) Tropical forest plant ecophysiology. Chapman and Hall, New York, pp 268-300.

Schulze E.D., Wirth Ch., Heimann M., 2000. Climate Change: managing forests after Kyoto. Science 289: 2058-2059.

Schroth G., Agra D'Angelo S., Geraldes Teixeira W., Haag D., Lieberei R., 2002. Conversion of secondary forest into agroforestry and monoculture plantations in Amazonia: consequences for biomass, litter and soil carbon stocks after 7 years. Forest Ecology and Management 163: 131-150. 
Silver W.L., Kueppers L.M., Lugo A.E., Ostertag R., Matzek V., 2004. Carbon sequestration and plant community dynamics following reforestation of tropical pasture. Ecological Applications 14: 1115-1127.

Silver W.L., Thompson A.W., McGroddy M.E., Varner, R.K., Dias, J.D., Silva, H., Crill, P.M., Kellers, M., 2005. Fine root dynamics and trace gas fluxes in two lowland tropical forest soils. Global Change Biology 11: 290-360.

Smith C.K., de Assis Oliveira F., Gholz H.L., Baima, A., 2002. Soil carbon stocks after forest conversion to tree plantations in lowland Amazonia, Brazil. Forest Ecology and Management 164: 257-263.

Sundarapandian S.M., Chandrasekaran S., Swamy P.S., 1996. Influence of disturbance on fine root biomass and productivity in two deciduous forests of Western Ghats Tamil Nadu. Current Science 70: 242-246.

Tilman D., 1985. The resource-ratio hypothesis of plant succession. American Naturalist 125: 827-852.

Trumbore S.E., Salazar da Costa E., Nepstad D.C., Barbosa de Camargo P., Martinelli L.A., Ray D., Restom T., Silver W.L., 2006. Dynamics of fine root carbon in Amazonian tropical ecosystems and the contribution of roots to soil respiration. Global Change Biology 12: 217-229.

Van Praag H.J., Sougenez-Remy S., Weissen F., Carletti G., 1988. Root turnover in a beech stand of the Belgian Ardennes. Plant and Soil 105: 87-103.

Vogt K.A., 1991. Carbon budgets of temperate forest ecosystems. Tree Physiology 9: 69-86.

Vogt K.A., Persson H., 1991. Measuring growth and development of roots. In: Lassoie, J.P., Hinkley, T.M. (eds.) Techniques and Approaches in Forest Tree Ecophysiology. CRC Press, Boca Raton FL, pp 447-502.

Vogt K.A., Vogt D.J., Palmiotto P.A., Boon P., O'Hara J., Asbjornsen H., 1996. Review of root dynamics in forest ecosystems grouped by climate, climatic forest type and species. Plant and Soil 187: 159-219.

Wells C.E., Eissenstat D.M., 2001. Marked differences in survivorship among apple roots of different diameters. Ecology 82: 882-892.

Xiao C.W., Curiel Yuste J., Janssens I.A., Roskams Nachtergale L., Carrara A., Sanchez B.Y., Ceulemans R., 2003. Above- and below-ground biomass and net primary production in a 73-year-old Scots pine forest. Tree Physiology 23: 505-516.

Yan J., Wang Y., Zhou G., Zhang D., 2006. Estimates of soil respiration and net primary production of three forests at different succession stages in South China. Global Change Biology 12: 810-821.

Yang Y.S., Chen G.S., Lin P., Xie J.S., Guo J.F., 2004. Fine root distribution, seasonal pattern and production in four plantations compared with a natural forest in Subtropical China. Annals of Forest Science 61: 617-627. 


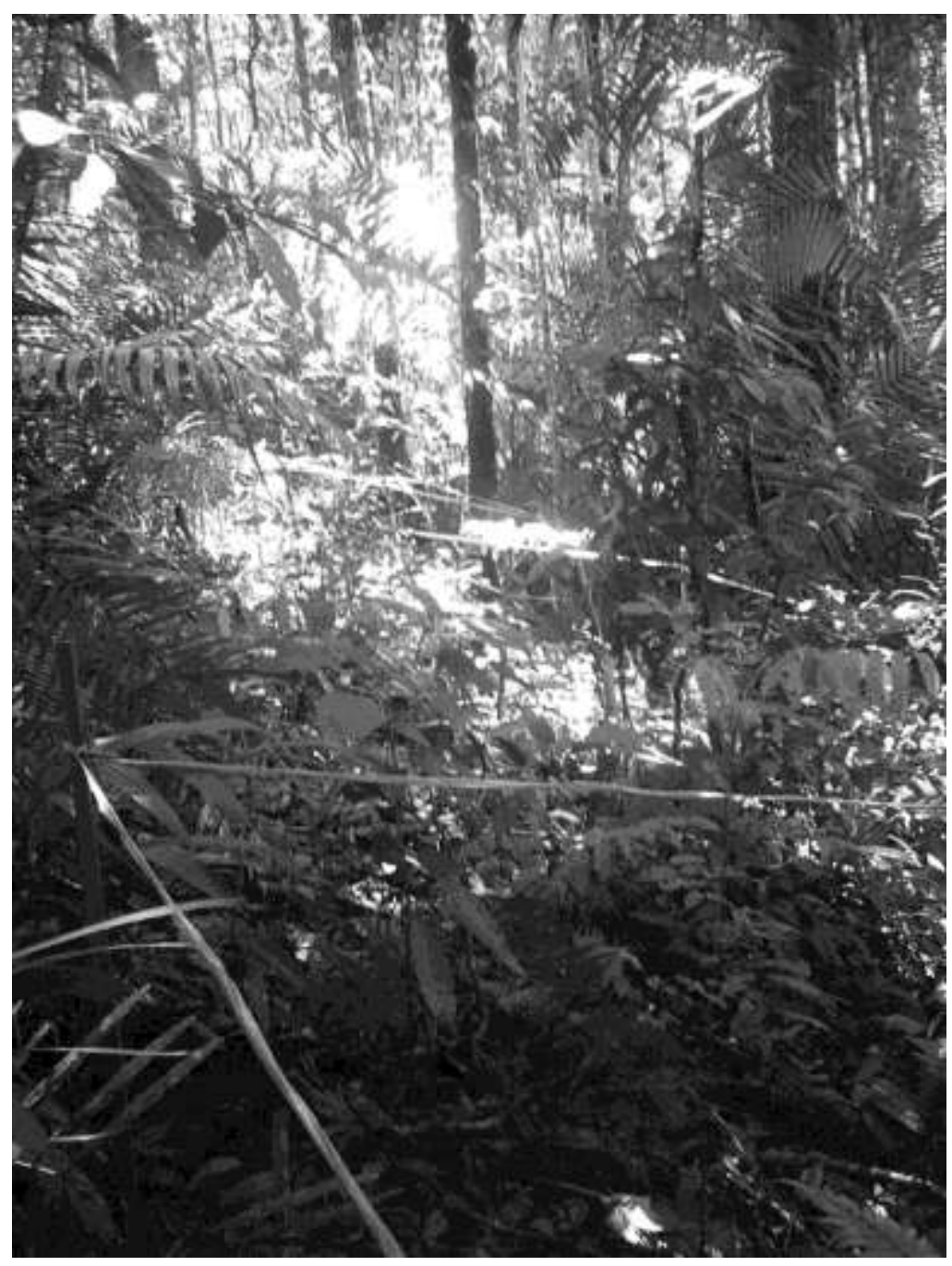




\section{Chapter 5}

Consequences of increasing forest use intensity for biomass, morphology and growth of fine roots in a tropical moist forest on Sulawesi, Indonesia. 
Abstract

To predict the impact of forest conversion in the tropics on the below ground carbon cycle, an improved understanding of the response of the fine root system to disturbance is needed. In a gradient study, we investigated the effect of increasing forest use intensity on fine root biomass, fine root morphology, and fine root growth of a tropical moist forest in Central Sulawesi, Indonesia. Twelve forest stands were selected representing four typical stages of forest disturbance in the region ranging from near-natural old growth forests to heavily disturbed cacao agroforestry systems under forest tree cover. Standing fine root biomass decreased markedly with increasing forest disturbance. Fine root growth showed a weak dependence on forest disturbance, whereas fine root recovery rate (growth per biomass) was distinctly higher in the more heavily disturbed stands. Specific root area was significantly higher in the stands with large timber extraction and fine root $\mathrm{N}$ concentration was particularly high in the cacao agroforestry stands; both root morphological traits were positively related to fine root growth rate. We conclude that the higher growth activity of fine roots in the moderately and heavily disturbed forests resulted from differences in fine root morphology and $\mathrm{N}$ content. This higher growth activity partly compensated for the decrease in fine root biomass with disturbance. 


\section{Introduction}

Fine roots are a prominent sink for carbon acquired through canopy photosynthesis (Nadelhoffer et al. 1992; Hendrick \& Pregitzer 1994; Jackson et al. 1997). Although tree fine roots represent only a few percent of the total tree biomass, they can consume 30 to $50 \%$ of the annual primary production (Vogt et al. 1996; Ruess et al. 1996; Xiao et al. 2003). Fast growth and turnover of fine roots make the fine root system a dynamic component of the forest carbon cycle (Silver et al. 2005). Therefore, the fine root system may have a large influence on how forests respond to anthropogenic disturbances (Powers 2004). Understanding controls of fine root turnover is crucial in order to predict how carbon and nutrient cycling, plant growth and plant productivity vary under environmental change (Eissenstat \& Yanai 1997).

Root morphology plays an important role in balancing costs and benefits of root growth and activity (Espleta and Donovan 2002) and therefore can have a strong impact on fine root turnover and, as a result, will affect soil carbon dynamics (Eissenstat 1992; Eissenstat 2000; Wahl and Ryser 2000; Comas et al. 2002). Functionally important morphological attributes of fine roots are specific root surface area, root tip abundance and the degree and type of mycorrhizal infection (Leuschner et al. 2004; Withington et al. 2006). By altering these morphological traits, plants can adapt their nutrient and water exploitation to the spatially and temporal varying distribution of resources in the soil (Fitter 1996). The cost/benefit ratio of the fine root system can be influenced by changing morphological features at the level of the individual root, or the entire root system (Leuschner et al. 2004).

Large areas of the remaining tropical rainforests are being logged and converted to agricultural systems at high rates (Nepstad et al. 1999; Achard et al. 2002). Forest conversion together with selective logging in the remaining stands can have a profound effect on the forest carbon cycle (Raich 1983; Lal 2005; Jandl et al. 2006). Even though intensive research has focussed on the effects of forest conversion on soil carbon (e.g. Smith et al. 2002; Schroth et al. 2002; Hairiah et al. 2006; Oelberman et al. 2006), data on the impact of anthropogenic disturbance on the fine root system of tropical forests is scarce (Vogt et al. 1996; Hertel et al. in press). Furthermore, most of the relevant studies focus on fine root mass, but rarely take fine root productivity and fine root morphology into account. In order to predict the influence of forest conversion on the below ground carbon cycle, a better insight in the effects of forest use intensity on the morphology of the fine root system and its dynamics is required.

By studying a sequence of forest stands differing in use intensity in the forest margin zone of Sulawesi, Indonesia, we analysed the impact of several widespread practices of tropical forest use in South-East Asia on important traits of the fine root system of tropical moist forests. In particular, we addressed the following questions:

1. What is the effect of increasing forest use intensity on standing fine root mass?

2. Are there differences in fine root morphological traits along the disturbance gradient? 
3. How is root growth activity affected by forest use intensity?

4. Which parameters influence root growth activity?

\section{Methods}

\section{Study area}

We conducted our study in the surroundings of the village of Toro in the western margin zone of the Lore Lindu National Park, Central Sulawesi, Indonesia $\left(01^{\circ} 39^{\prime} \mathrm{S}, 120^{\circ} 02^{\prime} \mathrm{E}\right)$. The Lore Lindu Park is one of the largest remaining areas of montane tropical rain forest in the region. Our study sites are situated in rugged terrain on moderately steep slopes (17-39 $)$ in the lower montane belt (elevation 815-1130 $\mathrm{m}$ a.s.l). The natural forest vegetation in the area is lower montane tropical moist forest. Common genera include Castanopsis (Fagaceae), Chionantus (Oleaceae), Dysoxylum (Meliaceae), Ficus (Moraceae) and Lithocarpus (Fagaceae) (Pitopang et al. 2005). The soils in the Toro region are predominantly well drained Cambisols (World Reference Base classification) with relatively high fertility, while occasionally also Ferralsols are present with a somewhat lower $\mathrm{pH}$ and soil fertility (Häring et al. 2005). Annual mean air temperature in the Toro area is about $23^{\circ} \mathrm{C}$ and yearly average precipitation is about $2200 \mathrm{~mm}$ ( $\mathrm{H}$. Kreilein, unpubl. data). Rainfall shows a moderate seasonality with at least $100 \mathrm{~mm}$ per month falling throughout the year. Air humidity ranges mostly between 75 and $90 \%$ throughout the year.

In the margins of the Lore Lindu National park, a number of forest use regimes differing in disturbance intensity are widespread. We selected 12 sites of $30 \mathrm{~m} \times 50 \mathrm{~m}$ representing four typical stages of forest disturbance ranging from near-natural old growth forests to cacao agroforestry systems (each forest use type was replicated three times). Due to the different management intensities, the forest types showed a clear differentiation with respect to canopy cover, mean diameter at breast height $(\mathrm{dbh})$ and cumulative basal area (Leuschner et al. 2006). The four forest use types were defined as follows: Forest use type $A$ is an oldgrowth natural forest with virtually no human impact (mean canopy cover $=90 \%$; mean tree height $=21 \mathrm{~m}$; mean total basal area $=52 \mathrm{~m}^{2} \mathrm{ha}^{-1} ;$ mean dbh $=29.5$, Dietz et al. 2006). Forest use type $B$ is a slightly disturbed forest characterized by the irregular extraction of small diameter stems (mean canopy cover $=86 \%$, mean tree height $=18.1 \mathrm{~m}$; mean total basal area $=47.1 \mathrm{~m}^{-2} \mathrm{ha}^{-1}$; mean $\mathrm{dbh}=26.9 \mathrm{~cm}$ ). Forest use type $\mathrm{C}$ represents a moderately disturbed forest with selective logging of large-diameter stems at irregular intervals (mean canopy cover $=82 \%$; mean tree height $=15 \mathrm{~m}$; mean total basal area $=37 \mathrm{~m}^{2} \mathrm{ha}^{-1}$; mean $\mathrm{dbh}=21.3 \mathrm{~cm}$ ). Forest use type $\mathrm{D}$ is an agroforestry system with cacao (Theobroma cacao) planted under a sparse shading cover of remaining forest trees (mean canopy cover $=70 \%$; mean tree height $=6.7 \mathrm{~m}$; mean total basal area $=22.8 \mathrm{~m}^{2} \mathrm{ha}^{-1} ;$ mean $\mathrm{dbh}=9.5 \mathrm{~cm}$ ). 


\section{Root sampling and analysis}

In order to assess standing fine root biomass, root samples were taken with a soil corer (3.5 $\mathrm{cm}$ in diameter) from the first $50 \mathrm{~cm}$ of the soil including the organic layer at six randomly selected sampling locations per study plot. To avoid clumping of the locations and to cope with the spatial heterogeneity of the plots, the samples were taken at a minimum distance of four meter from each other. Soil cores were separated into three depths (0-10, 10-20, 20-50 $\mathrm{cm}$ ). The soil samples were transferred to plastic bags and transported to the laboratory at the University of Palu, where processing of the stored samples $\left(4^{\circ} \mathrm{C}\right)$ took place within 45 days. In the lab, the samples were soaked in water and cleaned from soil residues using a sieve with a mesh size of $0.25 \mathrm{~mm}$. Only fine roots of trees (roots $<2 \mathrm{~mm}$ in diameter) were considered for analysis. Roots of grasses and herbs, which only were abundant in the agroforestry systems, were easily distinguished from tree fine roots by their smaller diameter, light colour and the absence of a woody periderm. Live fine roots (biomass) were separated from dead rootlets (necromass) under the stereomicroscope based on colour, root elasticity, and the degree of cohesion of cortex, periderm and stele. A dark cortex and stele, or a white, but non-turgid cortex, or the complete loss of the stele and cortex with only the periderm being present, were used as indicators of root death (Persson 1978; Leuschner et al. 2001). Fine root biomass of each sample was dried at $70^{\circ}$ (48 h) and weighed. The data was expressed as fine root abundance ( $\mathrm{g}$ d.m. $\mathrm{m}^{-2}$ ).

To gain insight in the overall fine root morphology at the 12 forest stands, we took fine root samples with a soil corer from the upper $20 \mathrm{~cm}$ of the soil at five randomly selected locations per study site. The samples were divided into two layers (0-10 and 10-20 cm) and transported to the lab in Palu, where the root samples were cleaned as described above. The cleaned samples were transferred to zip-lock bags and transported within a few days to the lab in Göttingen, Germany. There, one intact rootlet per sample and soil depth $(n=120$ in total) was used to determine the number of root tips per $\mathrm{g}$ of fine root mass. Additionally, the rootlets were analysed for fine root surface area (SRA, $\mathrm{cm}^{2} \mathrm{~g}^{-1}$ ) and fine root diameter using a WinRhizo (Régent, Quebec, Canada) image processing unit. Based on these data and the data on fine root biomass of the respective stands, we calculated tip frequency (number per $\mathrm{m}^{2}$ ) and root area index (RAl; $\mathrm{m}^{2}$ root surface area per $\mathrm{m}^{2}$ ground area). RAl and root tip frequency at $20-50 \mathrm{~cm}$ soil depth were extrapolated using the morphology data from the $10-20 \mathrm{~cm}$ soil horizon.

Additionally, mean fine root $\mathrm{C}$ and $\mathrm{N}$ concentrations from all four forest use types were established. Root samples from one representative stand per forest use type, were taken from the first $20 \mathrm{~cm}$ of the soil at 10 randomly selected locations and separated into two depths (0-10 and 10-20 cm). In the lab, in Palu, the roots were cleaned as described above and the $\mathrm{C}$ and $\mathrm{N}$ concentrations measured using a $\mathrm{CNH}$ auto-analyser.

An estimate of fine root growth capacity of the different forest use types was obtained by conducting ingrowth core experiments with local soil material in the first $10 \mathrm{~cm}$ of the soil, 
according to the methodology described by Persson (1980), Powell and Day (1991) and Majdi (1996). In order to cover a period of more than one year we installed ingrowth cores from January to July 2004 and from August 2004 until May 2005. At 10 randomly selected locations in each of the 12 stands, cores were cut from the topsoil (diameter $55 \mathrm{~mm}$, depth $10 \mathrm{~cm}$ ) at a minimum distance of five meter apart from each other. All macroscopically visible live and dead root material (> ca $10 \mathrm{~mm}$ length) was extracted by hand. Smaller dead rootlets were assumed to disappear by decomposition during the experiment. The remaining soil material was replaced into the hole and its edges were marked at the soil surface. Care was taken that the structure and density of the soil samples were conserved as much as possible. The samples were recollected with the soil corer after the respective exposure periods. In the laboratory, root biomass in the cores was extracted as described above. Following Vogt et al. (1998), we calculated fine root regrowth in the cores as the increase in root biomass from the start of root recolonisation (in our study 2 months after installation) until harvest. Fine root increment in the cores during the recolonisation period was extrapolated to one year and expressed in $\mathrm{g} \mathrm{d.m.} \mathrm{m}^{-2} \mathrm{yr}^{-1}$. To obtain a balanced estimate of fine root growth during a one-year-period we took the average of both recolonisation periods. We then extrapolated the data to $20 \mathrm{~cm}$ depth using the ratio of standing fine root biomass between the two soil layers. Finally we calculated the fine root recovery rate $\left(\mathrm{yr}^{-1}\right)$ in the ingrowth cores by relating the fine root increment recorded in the ingrowth cores after a oneyear recolonisation period to the fine root abundance observed in the surrounding, unmanipulated soil at the time of harvest. To measure the standing fine root abundance in the surrounding soil, additional soil cores were taken at approximately $30 \mathrm{~cm}$ distance from each of the ingrowth cores. These additional root samples were processed as described above.

\section{Statistical analysis}

Differences in standing fine root biomass, morphology and fine root growth between the four forest use types or between the different soil horizons were analysed using a nonparametric analysis of variance (Kruskal-Wallis test) and a Mann-Whitney two sample test (U-test). These calculations were done with the software package SPSS version 12.01 (SPSS Inc., Chicago, USA).

The dependence of SRA, RAI and root tip frequency on canopy cover, mean tree height, mean basal area, mean dbh, leaf area index (LAl), base saturation and soil $\mathrm{pH}$ was analysed by single factor linear, or non-linear, regression analyses (software package Xact version 7.12, SciLab, Hamburg, Germany). The same method was used to analyse the dependence of fine root growth, fine root recovery rate, RAI and root tip frequency on SRA, root tip abundance, fine root $\mathrm{N}$ content and fine root biomass. 


\section{Results}

\section{Fine root biomass}

Standing fine root biomass (FRB) gradually decreased from the undisturbed forest sites (type $A$ ) to the cacao plantations under natural shading cover (type $D$, Table 1). With a mean of $408 \mathrm{~g} \mathrm{~m}^{-2}$ the undisturbed forest stands (type A) had a significantly higher standing fine root biomass compared to all other forest use types. FRB in the disturbed forest stands with either small timber extraction (type B), large timber extraction (type C) or agroforestry (type D) did not differ significantly from each other, even though the mean FRB of type B was about $90 \mathrm{~g} \mathrm{~m}^{-2}$ higher than that of type $C$ and D. In all stands, 70 to $80 \%$ of the profile total of fine root biomass was found in the upper $20 \mathrm{~cm}$ of the soil.

Table 1 Standing fine root biomass in the upper $50 \mathrm{~cm}$ of the soil, including the organic layer (mean \pm 1 $\mathrm{SE})$. Forest disturbance increases from type $A$ to $D$. Different letters indicate significant differences between the respective soil horizons or profile totals of the forest types $(p<0.05)$.

\begin{tabular}{|c|c|c|c|c|}
\hline \multirow[b]{2}{*}{ Soil depth $(\mathrm{cm})$} & \multicolumn{4}{|c|}{ Fine Root Biomass $\left(\mathrm{g} \mathrm{m}^{-2}\right)$} \\
\hline & Forest use type $A$ & Forest use type $B$ & Forest use type C & Forest use type $D$ \\
\hline $0-10$ & $255.3 \pm 30.0 \quad a$ & $152.5 \pm 32.1 \quad b$ & $129.4 \pm 22.3 \quad b$ & $144.3 \pm 23.3$ \\
\hline $10-20$ & $71.7 \pm 21.0 \quad b$ & $67.1 \pm 25.6 \quad b$ & $49.8 \pm 10.7 \quad b$ & $44.1 \pm 10.0$ \\
\hline $20-50$ & $81.3 \pm 13.9 \quad a$ & $93.5 \pm 38.7 \quad a b$ & $46.0 \pm 10.9 \quad b$ & $41.1 \pm 9.1$ \\
\hline profile total & $408.3 \pm 47.0 \quad a$ & $313.2 \pm 79.5 \quad b$ & $225.2 \pm 32.1 \quad b$ & $229.4 \pm 29.8$ \\
\hline
\end{tabular}

\section{Morphology and $\mathrm{C}$ and $\mathrm{N}$ content of fine roots}

Average diameter of the fine root fraction $(<2 \mathrm{~mm}$ ) ranged between 0.61 and $0.85 \mathrm{~mm}$ and did not vary markedly with soil depth or forest use type (Table 2). Nevertheless, fine roots in the upper $10 \mathrm{~cm}$ of the soil tended to have a somewhat smaller diameter than those at 10-20 cm depth.

The mean specific root area (SRA) in the upper $10 \mathrm{~cm}$ of the soil increased from $203 \mathrm{~cm}^{2} \mathrm{~g}^{-1}$ in the undisturbed forest stands (type A) to $342 \mathrm{~cm}^{2} \mathrm{~g}^{-1}$ in the forest stands with large timber extraction (type $C$, Table 2). In the cacao agroforestry sites (type D), we observed intermediate SRA values $\left(258 \mathrm{~cm}^{2} \mathrm{~g}^{-1}\right)$ that were comparable to those in the forest stands with small timber extraction (type B). At 10-20 cm depth, there was generally less variation in SRA and no significant differences between the forest use types were observed. However, the highest SRA at 10-20 cm depth was found in type $D\left(251 \mathrm{~cm}^{2} \mathrm{~g}^{-1}\right)$, while the lowest SRA value in this soil horizon was found in type $C\left(177 \mathrm{~cm}^{2} \mathrm{~g}^{-1}\right.$; Table 2).

In the upper $10 \mathrm{~cm}$ of the soil, we found a gradual increase in the number of root tips per root biomass (root tip abundance) with increasing forest disturbance. Root tip abundance in this

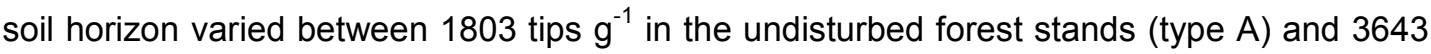
tips $\mathrm{g}^{-1}$ in the cacao plantations (type $\mathrm{D}$, Table 2). In contrast, no significant differences in 
fine root tip abundance were observed at 10-20 cm depth between the four forest use types. While in the forest stands with minor disturbance (type A and B) mean root tip abundance was similar at both soil depths, root tip abundance in the more heavily disturbed forest stands (type C and D) was markedly higher at 0-10 cm depth.

The $\mathrm{C}: \mathrm{N}$ ratio in the fine root biomass was significantly lower in the cacao agroforestry stand than in any of the forest stands (both soil horizons). The lower ratio was caused by both a significantly higher $\mathrm{N}$ concentration and a significantly lower $\mathrm{C}$ concentration in fine roots of type D (Table 3). Among the A, B, C, forest stands, fine roots of the undisturbed forest (type A) had the lowest $\mathrm{N}$ concentration. This was valid for both soil depths.

Table 2 Mean fine root diameter, specific root area and root tip abundance at 0-10 and $10-20 \mathrm{~cm}$ soil depth (mean $\pm 1 \mathrm{SE}$ ) of the four forest use types. Different Latin letters indicate significant differences between the forest use types, different Greek letters significant differences between the soil horizons ( $p$ $<0.05)$.

\begin{tabular}{|c|c|c|c|c|c|c|c|}
\hline \multirow[t]{2}{*}{$\begin{array}{l}\text { Forest-use } \\
\text { type }\end{array}$} & \multirow{2}{*}{$\begin{array}{l}\begin{array}{l}\text { Soil depth } \\
(\mathrm{cm})\end{array} \\
\\
0-10 \\
10-20\end{array}$} & \multicolumn{2}{|c|}{$\begin{array}{l}\text { Fine root diameter } \\
(\mathrm{mm})\end{array}$} & \multicolumn{2}{|c|}{$\begin{array}{l}\text { Specific root area } \\
\left(\mathrm{cm}^{2} \mathrm{~g}^{-1}\right)\end{array}$} & \multicolumn{2}{|c|}{$\begin{array}{l}\text { Root tip abundance } \\
\left(\mathrm{n} \mathrm{g}^{-1}\right)\end{array}$} \\
\hline & & $\begin{array}{l}0.63 \pm 0.04 \\
0.85 \pm 0.08\end{array}$ & $\begin{array}{ll}\alpha & a \\
\beta & a\end{array}$ & $\begin{array}{l}203.0 \pm 22.3 \\
217.1 \pm 33.2\end{array}$ & $\begin{array}{ll}\alpha & \mathrm{a} \\
\alpha & \mathrm{a}\end{array}$ & $\begin{array}{l}1803 \pm 423 \\
1922 \pm 404\end{array}$ & $\begin{array}{ll}\alpha & a \\
\alpha & a\end{array}$ \\
\hline B & $\begin{array}{r}0-10 \\
10-20\end{array}$ & $\begin{array}{l}0.61 \pm 0.06 \\
0.69 \pm 0.07\end{array}$ & $\begin{array}{ll}\alpha & \mathrm{a} \\
\alpha & \mathrm{ab}\end{array}$ & $\begin{array}{l}237.0 \pm 25.0 \\
223.5 \pm 28.5\end{array}$ & $\begin{array}{ll}\alpha & a b \\
\alpha & a\end{array}$ & $\begin{array}{l}2298 \pm 442 \\
2360 \pm 516\end{array}$ & $\begin{array}{ll}\alpha & a b \\
\alpha & a\end{array}$ \\
\hline C & $\begin{array}{r}0-10 \\
10-20\end{array}$ & $\begin{array}{l}0.62 \pm 0.06 \\
0.70 \pm 0.08\end{array}$ & $\begin{array}{ll}\alpha & a \\
\alpha & a b\end{array}$ & $\begin{array}{l}342.2 \pm 62.5 \\
176.6 \pm 26.3\end{array}$ & $\begin{array}{ll}\alpha & b \\
\beta & a\end{array}$ & $\begin{array}{l}3187 \pm 602 \\
2004 \pm 624\end{array}$ & $\begin{array}{ll}\alpha & b \\
\beta & a\end{array}$ \\
\hline$D$ & $\begin{array}{r}0-10 \\
10-20\end{array}$ & $\begin{array}{l}0.61 \pm 0.08 \\
0.63 \pm 0.04\end{array}$ & $\begin{array}{ll}\alpha & a \\
\alpha & b\end{array}$ & $\begin{array}{l}258.0 \pm 42.5 \\
250.8 \pm 43.9\end{array}$ & $\begin{array}{ll}\alpha & a b \\
\alpha & a\end{array}$ & $\begin{array}{l}3643 \pm 910 \\
2060 \pm 259\end{array}$ & $\begin{array}{ll}\alpha & a b \\
\alpha & a\end{array}$ \\
\hline
\end{tabular}

Table 3 Fine root $C$ and $N$ content $(\%)$ at $0-10$ and $10-20 \mathrm{~cm}$ soil depth (mean \pm 1 SE). Different letters indicate significant differences between the forest types $(p<0.05)$.

\begin{tabular}{|c|c|c|c|c|c|c|c|}
\hline $\begin{array}{l}\text { Forest-use } \\
\text { type }\end{array}$ & $\begin{array}{l}\text { Soil depth } \\
(\mathrm{cm})\end{array}$ & $\begin{array}{l}\text { Fine root } \\
\mathrm{N}(\%)\end{array}$ & & $\begin{array}{l}\text { Fine root } \\
\mathrm{C}(\%)\end{array}$ & & $\begin{array}{l}\text { Fine root } \\
\mathrm{C}: \mathrm{N}\end{array}$ & \\
\hline$A$ & $\begin{array}{r}0-10 \\
10-20\end{array}$ & $\begin{array}{l}1.06 \pm 0.04 \\
1.01 \pm 0.05\end{array}$ & $\begin{array}{l}a \\
a\end{array}$ & $\begin{array}{l}42.5 \pm 1.1 \\
42.3 \pm 0.9\end{array}$ & $\begin{array}{l}\mathrm{a} \\
\mathrm{a}\end{array}$ & $\begin{array}{l}40.2 \pm 1.1 \\
42.5 \pm 1.9\end{array}$ & $\begin{array}{l}\mathrm{a} \\
\mathrm{a}\end{array}$ \\
\hline$B$ & $\begin{array}{r}0-10 \\
10-20\end{array}$ & $\begin{array}{l}1.18 \pm 0.04 \\
1.08 \pm 0.05\end{array}$ & $\begin{array}{l}\mathrm{b} \\
\mathrm{a}\end{array}$ & $\begin{array}{l}42.3 \pm 0.6 \\
43.4 \pm 0.6\end{array}$ & $\begin{array}{l}a \\
a\end{array}$ & $\begin{array}{l}36.9 \pm 1.2 \\
41.1 \pm 1.9\end{array}$ & $\begin{array}{l}\mathrm{a} \\
\mathrm{a}\end{array}$ \\
\hline C & $\begin{array}{r}0-10 \\
10-20\end{array}$ & $\begin{array}{l}1.17 \pm 0.09 \\
1.04 \pm 0.09\end{array}$ & $\begin{array}{l}a b \\
a\end{array}$ & $\begin{array}{l}45.7 \pm 1.0 \\
44.9 \pm 1.2\end{array}$ & $\begin{array}{l}\mathrm{b} \\
\mathrm{a}\end{array}$ & $\begin{array}{l}40.0 \pm 1.3 \\
43.5 \pm 1.6\end{array}$ & $\begin{array}{l}\mathrm{a} \\
\mathrm{a}\end{array}$ \\
\hline $\mathrm{D}$ & $\begin{array}{r}0-10 \\
10-20\end{array}$ & $\begin{array}{l}1.79 \pm 0.11 \\
1.66 \pm 0.10\end{array}$ & $\begin{array}{l}c \\
b\end{array}$ & $\begin{array}{l}39.0 \pm 1.2 \\
37.2 \pm 1.6\end{array}$ & $\begin{array}{l}c \\
b\end{array}$ & $\begin{array}{l}22.6 \pm 1.6 \\
23.2 \pm 1.9\end{array}$ & $\begin{array}{l}\mathrm{b} \\
\mathrm{b}\end{array}$ \\
\hline
\end{tabular}

\section{Root area index and root tip frequency at stand level}

The average root area index $\left(\mathrm{RAI}, \mathrm{m}^{2} \mathrm{~m}^{-2}\right)$ in the upper $50 \mathrm{~cm}$ of the soil was largest in the undisturbed forest $\left(8.5 \mathrm{~m}^{2} \mathrm{~m}^{-2}\right.$, Figure 1a). Surprisingly, even minor timber extraction reduced RAl significantly by more than $20 \%$. As a result of an increase in specific root 
surface area, the mean RAI in the forest stand with large timber extraction (type C) and the agroforestry stand (type D) differed not significantly from that in the forest stand with a much lower disturbance level (type B) despite a tendency towards reduced root biomass. The root tip frequency $\left(\mathrm{n} \mathrm{m}^{-2}\right)$ in the upper $50 \mathrm{~cm}$ of the soil did not differ significantly between the four forest use types (Figure $1 \mathrm{~b}$ ). Within the three stands $A, B$ and $C$, root tip frequency tended to decrease with increasing disturbance intensity from $0.79 \cdot 10^{6} \mathrm{~m}^{-2}$ to $0.64 \cdot 10^{6} \mathrm{~m}^{-2}$. However, the cacao agroforestry stand had the highest number of root tips per square meter $(0.80$ $\left.\cdot 10^{6}\right)$. The RAI values and the root tip frequency of the most heavily disturbed stands $(C, D)$ were especially high in the uppermost soil horizon $(0-10 \mathrm{~cm})$, while the lower soil horizons contained only few tips.
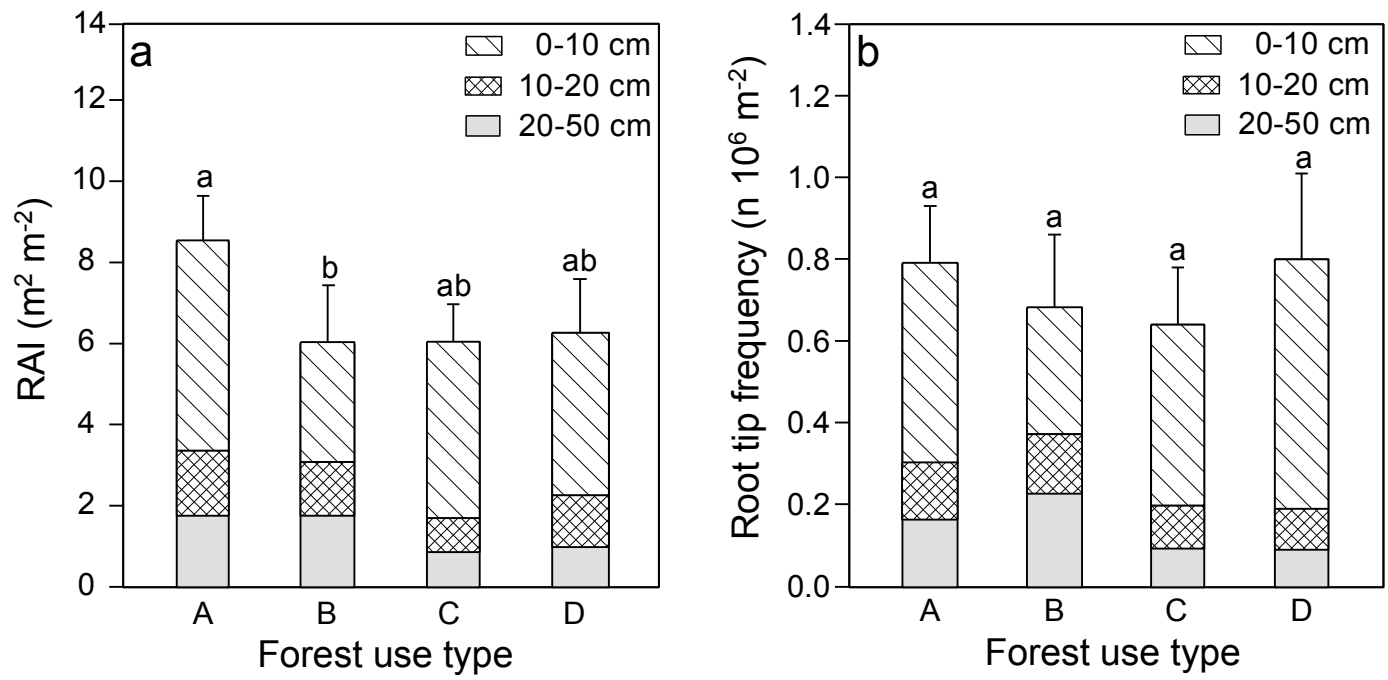

Figure 1 Mean root area index (RAI) and root tip frequency in the four forest use types at $0-10,10-20$ and $20-50 \mathrm{~cm}$ depth (mean $\pm 1 \mathrm{SE}$ ). Different letters indicate significant differences between the forest use types at $p<0.05$.

\section{Fine root growth}

The growth of fine roots in the ingrowth cores placed in the upper $10 \mathrm{~cm}$ of the soil was significantly higher in the undisturbed forests (type A) than in the forest stands with small timber extraction (type B, Fig. 2a). In the forest stands with large timber extraction and the cacao agroforestry stands, on the other hand, fine root growth was only marginally lower than in the undisturbed forest stands.

The fine root recovery rate (fine root growth per biomass $\mathrm{yr}^{-1}$ ), showed a different pattern. With mean values of $0.86 \mathrm{yr}^{-1}$ and $0.79 \mathrm{yr}^{-1}$ the fine root recovery rate in the undisturbed and slightly disturbed stands (type A and B) was markedly lower than in the stands with large timber extraction or agroforestry (type $C$ and D) with mean recovery rates of $1.25 \mathrm{yr}^{-1}$ and $1.27 \mathrm{yr}^{-1}$, respectively (Figure $2 \mathrm{~b}$ ). Although the mean fine root recovery rate in type $\mathrm{C}$ was relatively high $\left(1.25 \mathrm{yr}^{-1}\right)$, the difference to the other types was not significant due to a large variation in those stands. 

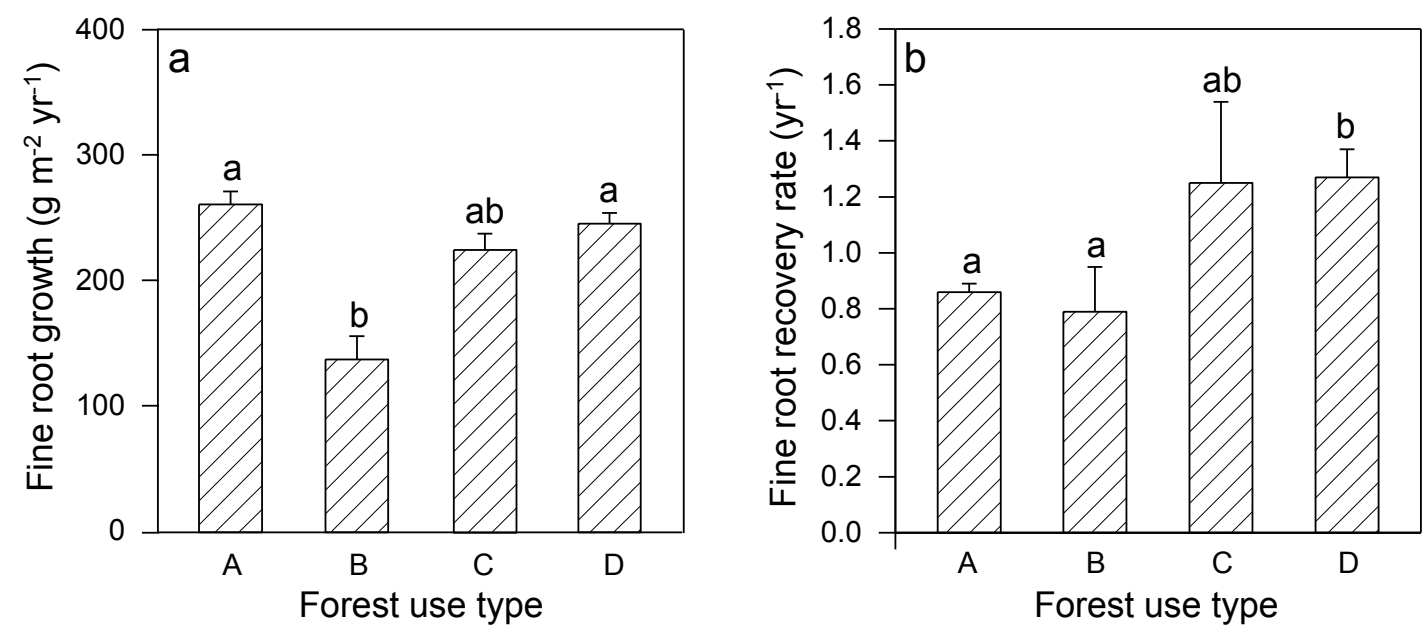

Figure 2 Fine root growth and fine root recovery rate in the upper $10 \mathrm{~cm}$ of the soil, as estimated with the ingrowth core method (mean $\pm 1 \mathrm{SE}$ ). Different letters indicate significant differences between the forest use types at $p<0.05$.

Table 4 Correlation coefficients of linear or simple exponential ( ${ }^{*}$ ) regressions of various factors of above-ground forest structure and soil conditions on profile totals of standing fine root biomass, root area index (RAI) and root tip frequency, and on fine root growth and fine root recovery rate in the upper $10 \mathrm{~cm}$ of the soil of the four forest use types. Significant relationships $(p<0.05)$ are printed in bold.

\begin{tabular}{|c|c|c|c|c|}
\hline Parameter & Source & $\mathbf{r}$ & $\mathbf{r}^{2}{ }_{\text {adj }}$ & $\mathbf{p}$ \\
\hline $\begin{array}{l}\text { Fine root biomass } \\
\left(\mathrm{g} \mathrm{m}^{-2}\right)\end{array}$ & $\begin{array}{l}\text { Canopy cover * } \\
\text { Tree height * } \\
\text { Basal area } \\
\text { Base saturation * } \\
\text { pH }\end{array}$ & $\begin{array}{r}0.58 \\
0.42 \\
0.11 \\
0.16 \\
-0.08\end{array}$ & $\begin{array}{r}\mathbf{0 . 2 7} \\
0.09 \\
-0.01 \\
-0.07 \\
-0.09\end{array}$ & $\begin{array}{r}<0.05 \\
0.17 \\
0.73 \\
0.62 \\
0.81\end{array}$ \\
\hline $\begin{array}{l}\text { Fine root growth } \\
\left(\mathrm{g} \mathrm{m}^{-2} \mathrm{yr}^{-1}\right)\end{array}$ & $\begin{array}{l}\text { Canopy cover * } \\
\text { Tree height } \\
\text { Basal area } \\
\text { Base saturation } \\
\text { pH }\end{array}$ & $\begin{array}{r}-0.02 \\
-0.03 \\
-0.03 \\
0.08 \\
-0.02\end{array}$ & $\begin{array}{l}-0.10 \\
-0.10 \\
-0.10 \\
-0.09 \\
-0.10\end{array}$ & $\begin{array}{l}0.92 \\
0.93 \\
0.92 \\
0.81 \\
0.95\end{array}$ \\
\hline $\begin{array}{l}\text { Fine root recovery rate } \\
\left(\mathrm{yr}^{-1}\right)\end{array}$ & $\begin{array}{l}\text { Canopy cover * } \\
\text { Tree height * } \\
\text { Basal area } \\
\text { Base saturation } \\
\text { pH }\end{array}$ & $\begin{array}{r}\mathbf{0 . 5 7} \\
\mathbf{0 . 5 8} \\
0.27 \\
-0.14 \\
0.24\end{array}$ & $\begin{array}{r}\mathbf{0 . 2 5} \\
\mathbf{0 . 2 6} \\
-0.02 \\
-0.08 \\
-0.04\end{array}$ & $\begin{array}{l}\mathbf{0 . 0 5} \\
\mathbf{0 . 0 5} \\
0.41 \\
0.67 \\
0.46\end{array}$ \\
\hline $\begin{array}{l}\mathrm{RAI} \\
\left(\mathrm{m}^{2} \mathrm{~m}^{-2}\right)\end{array}$ & $\begin{array}{l}\text { Canopy cover } \\
\text { Tree height } \\
\text { Basal area } \\
\text { Base saturation } \\
\text { pH }\end{array}$ & $\begin{array}{r}0.15 \\
0.16 \\
-0.05 \\
0.12 \\
0.22\end{array}$ & $\begin{array}{l}-0.08 \\
-0.07 \\
-0.10 \\
-0.08 \\
-0.05\end{array}$ & $\begin{array}{l}0.64 \\
0.61 \\
0.88 \\
0.71 \\
0.50\end{array}$ \\
\hline $\begin{array}{l}\text { Root tip frequency } \\
\left(\mathrm{n} \mathrm{m}^{-2}\right)\end{array}$ & $\begin{array}{l}\text { Canopy cover } \\
\text { Tree height } \\
\text { Basal area } \\
\text { Base saturation } \\
\mathrm{pH}^{*}\end{array}$ & $\begin{array}{r}-0.01 \\
-0.02 \\
-0.25 \\
0.16 \\
0.49\end{array}$ & $\begin{array}{r}-0.01 \\
-0.09 \\
-0.03 \\
-0.07 \\
0.17\end{array}$ & $\begin{array}{l}0.97 \\
0.96 \\
0.43 \\
0.63 \\
0.10\end{array}$ \\
\hline
\end{tabular}


Table 5 Correlation coefficients of linear regressions of fine root biomass $\left(\mathrm{g} \mathrm{m}^{-2}\right)$, specific root surface area $\left(\mathrm{cm}^{-2} \mathrm{~g}^{-1}\right)$ and root tip abundance $\left(\mathrm{n} \mathrm{g}^{-1}\right)$ on fine root growth $\left(\mathrm{g} \mathrm{m}^{-2} \mathrm{yr}^{-1}\right)$ and fine root recovery rate $\left(\mathrm{yr}^{-1}\right)$ in the upper $10 \mathrm{~cm}$ of the soil of the four forest use types. Significant correlations are printed in bold.

\begin{tabular}{llrrr}
\hline Parameter & Source & $r$ & $r^{2}$ & \multicolumn{1}{c}{$P$} \\
\hline Fine root growth & Fine root biomass & $\mathbf{0 . 7 1}$ & $\mathbf{0 . 5 0}$ & $<\mathbf{0 . 0 1}$ \\
$(0-10 \mathrm{~cm})$ & Specific root area & -0.31 & 0.10 & 0.32 \\
& Root tip abundance & 0.17 & 0.03 & 0.60 \\
& & & & \\
Fine root recovery rate & Fine root biomass & $\mathbf{- 0 . 5 8}$ & $\mathbf{0 . 3 1}$ & $<\mathbf{0 . 0 5}$ \\
$(0-10 \mathrm{~cm})$ & Specific root area & $\mathbf{0 . 6 7}$ & $\mathbf{0 . 4 4}$ & $<\mathbf{0 . 0 5}$ \\
& Root tip abundance & 0.14 & 0.02 & 0.68 \\
\hline
\end{tabular}

\section{Influence of stand structure and soil chemistry on fine root parameters}

Regression analyses showed significant relationships between stand structure and various fine root parameters. The profile total of standing fine root biomass was positively related to the canopy cover of the stands (Table 4). Fine root biomass increased on average by about $80 \%$ from a forest stand with $70 \%$ canopy cover to a stand with $90 \%$ cover. Profile totals of RAl and root tip abundance did not demonstrate any direct relationship with the stand structural parameters. While no relationship between stand structure and fine root growth could be detected, we observed a negative relationship between fine root recovery rate and canopy cover and between fine root recovery rate and mean tree height of the stands (Table 4). Finally, none of the fine root parameters showed a correlation with the base saturation and $\mathrm{pH}$ of the soil.

\section{Inter-correlations between different fine root traits}

Tests of inter-correlation between the various measured fine root parameters revealed that annual fine root growth in the ingrowth cores at $0-10 \mathrm{~cm}$ was positively related to fine root biomass in that horizon. In contrast, fine root recovery rate was negatively related to fine root biomass at $0-10 \mathrm{~cm}$ (Table 5). Specific root area, on the other hand, was positively related to fine root recovery rate. Fine root recovery rate itself increased exponentially with increasing fine root $\mathrm{N}$ concentration $\left(r^{2}{ }_{\text {adj }}=0.84, p=0.05\right.$; data not shown). 


\section{Discussion}

\section{Standing fine root biomass}

Profile totals of fine root biomass decreased gradually with increasing forest use intensity, with a more than $40 \%$ reduction in the heavily disturbed stands of type $C$ and $D$ as compared to the undisturbed stands of type A. All disturbed forest stands had significantly lower standing FRB values than the undisturbed forest stands. Interestingly even the extraction of small timber resulted in a significant decrease in FRB, while no significant differences were found between the three disturbed forest types ( $B, C, D)$. Other studies of natural or anthropogenic disturbances in tropical forests reported similar reductions in FRB due to disturbance (Silver \& Voigt 1993; Sundarapandian \& Swamy 1996; Sundarapandian et al. 1999; Hertel et al. 2007).

The reduction in FRB after selective logging or conversion into cacao agroforestry systems could, in theory, be explained by alterations in the above ground structure including the reduction of overall canopy cover and basal area, by enhanced soil temperatures in the gaps leading to altered soil moisture and/or nitrogen regimes, or by a decrease in nutrient supply due to a decrease in litter input. According to correlation analyses, there was no significant relationship between the cumulative basal area of the stands and total standing fine root biomass. Thus, the reduction in wood biomass per se due to timber harvest apparently did not cause the root biomass reduction. On the other hand, we found a significant positive relationship between canopy cover and fine root biomass. This would, to a certain extent, confirm the root gap theory of Wilczynski and Picket (1993), which assumes a thinning of the root "canopy" as a result of a thinning of the leaf canopy. However, as no relationship between fine root biomass and the distance between sampling location and the nearest tree was observed in our stands we rather hypothesize that an overall thinning of the fine root system in the entire stand must have occurred with a decrease in canopy cover (Harteveld et al. submit.).

\section{Specific fine root area and root tip abundance}

Specific fine root surface area (expressed as $\mathrm{cm}^{2}$ per $\mathrm{g}$ biomass) in the upper $10 \mathrm{~cm}$ of the soil was markedly higher in the moderately disturbed forest stands (type $\mathrm{C}$ ) compared the other forest use types. Higher SRA can either be achieved through smaller root diameters or through lower tissue densities (Eissenstat 1991). In our study, average fine root diameter did not differ significantly between the forest use types. Therefore, we assume that the particularly high SRA in the topsoil of forest use type $C$ is mainly caused by lower root tissue densities in these stands with abundant regrowth of young, light-demanding trees in the gaps.

Abiotic factors can have a strong influence on fine root morphology. Ostonen et al. (1999) found that differences in soil nutrient and soil water regimes explained about $30 \%$ of the 
observed root morphological differences in different stands of Norway spruce, while Leuschner et al. (2004) observed a significantly higher root tip abundance in acidic soils compared to basic soils. In the present study, on the other hand, we did not find any significant influence of soil chemical parameters on SRA or tip abundance. The lack of influence of soil parameters on root morphology in this study can most likely be attributed to the relatively small differences in soil acidity and nutrient availability between the stands.

Biotic factors like the availability of soluble carbohydrates and the potential growth rate of a tree species can influence the expression of morphological characteristics of fine roots as well. Roots of fast-growing species seem to possess specific adaptations for fast root growth into unexploited soil patches and generally have a higher SRA, a higher root tip abundance, a greater degree of branching and lower concentrations of phenolic substances compared to slow-growing species (Nicotra et al. 2002; Comas \& Eissenstat 2004). The SRA values (203 - $342 \mathrm{~cm}^{2} \mathrm{~g}^{-1}$ ) and root tip abundance values (1803 - $3643 \mathrm{n} \mathrm{g}^{-1}$ ) found in our study were comparable to those found in Costa Rican montane rainforests of different successional stages, which showed SRA values between 247 and $591 \mathrm{~cm}^{2} \mathrm{~g}^{-1}$ and tip abundance $\left(\mathrm{n} \mathrm{g}^{-1}\right)$ between 1400 and 3400 (Hertel et al. 2003).

A tree species inventory of our study plots revealed that relatively more fast-growing trees with low wood density were present in the stands with previous large timber extraction (type C), compared to the other forest stands (M. Kessler, pers. com.). Early-successional species generally have a higher potential growth rate than mid- or late-successional species under high light conditions (Wright et al. 2003; Gilbert et al. 2006). Tyree et al. (1998) found that tropical pioneer species produced significantly more root area and length per $\mathrm{g}$ dry matter investment than shade-tolerant species. Zangaro et al. (2005) also reported a decrease in SRA and root tip abundance toward late successional communities.

The growth of cacao trees is characterized by 2-3 flushes per year and root tip abundance therefore often shows an episodic pattern (Kummerow et al. 1982; Sleigh et al. 1984). However, as these flushes do not occur simultaneously in all cacao trees of a stand, it is not likely that the high stand average of root tip abundance observed in our study is caused by such a flush in growth. We assume that the high SRA values in the stands of forest use type $\mathrm{C}$ are most likely a consequence of the abundance of fast growing, early successional trees in these stands, while the high tip abundance in forest use type $D$ might be related to the presence of cacao trees and their specific root morphology.

\section{Root area index and root tip frequency}

In a review on fine root mass and surface area, Jackson et al. (1997) found a mean RAI value of $7.4 \mathrm{~m}^{2} \mathrm{~m}^{-2}$ for tropical evergreen forests world wide. With averages between 6.0 and $8.5 \mathrm{~m}^{2} \mathrm{~m}^{-2}$ the RAl values observed in our study are close to this estimated global average. No significant differences in root tip frequency were found between the different forest use types and only the undisturbed forest stands and the stands with small timber extraction 
differed in terms of RAI. This lack of significant variation in RAl and root tip frequency among the forest use types is mainly due to the fact that RAI and root tip frequency are a function of standing fine root biomass on the one hand, and the morphological parameters SRA and tip abundance on the other hand, which showed contrasting patterns along the disturbance gradient. While fine root biomass significantly decreased along the disturbance gradient, specific root area and tip abundance increased with increasing forest disturbance. This allows to conclude that the fine root systems in the heavily disturbed stands with an increasing proportion of young early-successional trees were able to partly compensate the loss in biomass by a specific increase in absorbing root surface area. Hertel et al. (2003) found a similar pattern in three Costa Rican rainforests, where fine root biomass increased while SRA and tip abundance decreased with proceeding succession. In the studies of Hertel et al. (2003) and Berish (1982; 1988) RAl increased with an increasing participation of late-successional trees despite a decrease in SRA.

\section{Fine root growth and recovery rate}

Fine root growth, as estimated with ingrowth cores, seemed to decline with an intensification of forest use and was distinctly lower in the forest stands with small timber extraction (type B) compared to the undisturbed forest stands (type A). Surprisingly, fine root growth increased again with a further intensification of forest use. This might be explained by a combination of factors. First, fine root growth on a ground area basis strongly increases with standing fine root biomass, which is significantly lower in the stands with small timber extraction (type B) compared to the undisturbed forest stands (type A). Second, even though the amount of fine root biomass in forest use type $B$ was comparable to that of type $C$ and $D$, the fine root recovery rate in type $B$ was much lower than in type $C$ and $D$.

How can the observed differences in fine root recovery rate be explained? Given that root morphology affects root maintenance and construction costs, faster fine root turnover is expected in species with roots characterized by high SRA and a low tissue density (Espleta et al. 2002) as well as in roots characterized by small diameter and little lignification (Eissenstat 1992; Eissenstat 2000; Wahl and Ryser 2000; Comas et al. 2002). High recovery rates in the in the more heavily disturbed forest types $C$ and $D$ were positively correlated with SRA. A root system consisting of energetically less expensive roots can not only more easily re-allocate root length in favourable soil patches, but might also be more responsive to root pruning (e.g. herbivory or mechanical disturbance) than root systems which invest more in biomass and possibly more in defence compounds (Eissenstat 1991). Thus, a higher SRA and a more rapid root recovery in the $C$ and $D$ stands can be judged as adaptive processes to the higher disturbance levels in these stands.

Besides SRA and tissue density, root characteristics such as $\mathrm{N}$ concentration or mycorrhizal infection can also have a significant impact on fine root dynamics. Tissue $\mathrm{N}$ is a key factor in understanding $\mathrm{C}$ costs of maintaining fine roots (Pregitzer et al. 2002). Roots with high $\mathrm{N}$ 
concentrations also have higher respiration rates; therefore, fine root construction and maintenance costs are inversely related (Pregitzer et al. 1998; Pregitzer et al. 2002), which affects fine root longevity. In fact, Whithington et al. (2006) found that root C:N ratio was the only root characteristic that significantly correlated with fine root life span for eleven temperate woody species tested in their study. These authors together with Comas et al. (2002) found that fast growing species had higher root $\mathrm{N}$ concentrations and lower C:N ratios than slow growing species. We found significantly higher $\mathrm{N}$ concentrations in the roots of the cacao plantations compared to the roots of the forest stands and a positive relationship between fine root $\mathrm{N}$ concentration and fine root recovery rate in the studied stands. Thus, cacao trees replacing rainforest trees are likely to speed up fine root turnover and associated $\mathrm{C}$ and $\mathrm{N}$ fluxes between roots and soil due to a comparatively high tip frequency, SRA and root $\mathrm{N}$ content which all should favour a short root lifespan.

\section{Conclusion}

We conclude that forest disturbance has a profound impact on fine root standing mass, fine root growth and fine root morphology of moist tropical forests in South-east Asia. Even minor disturbances, like irregular extraction of small-diameter stems, cause a significant reduction of standing fine root biomass. Root morphology of species replacing the extracted natural trees can differ significantly from that of the remaining vegetation. Both the fast growing early-successional species that colonize the gaps as well as the planted agroforestry species were found to have a larger SRA and root tip abundance compared to the tree species in the undisturbed stands. The larger SRA and root tip abundance in the more heavily disturbed sites levelled out some of the root-mass-based differences in RAI and root tip frequency. Higher fine root recovery rates were observed in the stands with a higher abundance of young, fast growing species and in the cacao agroforestry stands and seem to be a result of a higher SRA and tip abundance and higher root $\mathrm{N}$ concentrations.

\section{References}

Achard F., Eva H.D., Stibig H.J., Mayaux P., Gallego J., Richards T., Malingreau J.P., 2002. Determination of deforestation rates of the world's humid tropical forests. Science 297: 999-1002.

Asbjornsen H., Velazques-Rosas N., Garcia-Soriano R., Gallardo-Hernandez C., 2005. Deep ground fires cause massive above- and below-ground biomass losses in tropical montane cloud forests in Oaxaca, Mexico. Journal of Tropical Ecology 21: 427-434.

Berish C.W., 1982. Root biomass and surface area in three successional tropical forests. Canadian Journal of forest restoration 12: 699-704.

Berish C.W., Ewel J.J., 1988. Root development in simple and complex tropical successional ecosystems. Plant and soil 106: 73-84.

Bolte A., Villanueva I., 2006. Interspecific competition impacts on the morphology and distribution of fine roots in European beech (Fagus sylvatica L.) and Norway spruce (Picea abies). European Journal of Forest Research 125: 15-26. 
Comas L.H., Bouma T.J., Eissenstat D.M., 2002. Linking root traits to potential growth rate in six temperate tree species. Oecologia 132: 34-43.

Comas L.H., Eissenstat D.M., 2004. Linking fine root traits to maximum potential growth rate among 11 mature temperate tree species. Functional Ecology 18: 388-397.

Cooke F.P., Brown J.P., Mole, S. 1984. Herbivory, foliar enzyme inhibitors, nitrogen and leaf structure of young and mature leaves in a tropical forest. Biotropica 16: 257-263.

Dietz J., Hölscher D., Leuschner Ch., Malik A., Amir M.A., 2006. Forest structure as influenced by type of community forestry in a lower montane rainforest of Sulawesi, Indonesia. In: Tscharntke T, Leuschner Ch, Zeller M, editors. The Stability of Tropical Rainforest Margins: Linking Ecological, Economic and Social Constraints. Berlin: Springer.

Eissenstat D.M., 1991. On the relationship between specific root length and the rate of root proliferation: a field study using citrus rootstocks. New Phytologist 188: 63-68.

Eissenstat D.M., 1992. Costs and benefits of constructing roots of small diameter. Journal of Plant Nutrition 15: 763-782.

Eissenstat D.M., Yanai R.D., 1997. The ecology of root lifespan. Advances in Ecological Research 27: 1-60.

Eissenstat D.M., Wells C.E., Yanai R.D., Whitbeck J.L., 2000. Building roots in a changing environment: implications for root longevity. New Phytologist 147: 33-42.

Espeleta J.F., Donovan L.A., 2002. Fine root demography and morphology in response to soil resources availability among xeric and mesic sandhill tree species. Functional Ecology 16: 113-121.

Fitter A., 1996. Characteristics and functions of root systems. In: Waisel Y., Eshel A., Kafkafi U. (eds.) Plant roots: the hidden half. Dekker, New York.

Fitter A.H., Graves J.D., Self G.K., Brown T.K., Bogie D.S., Taylor K., 1998. Root production, turnover and respiration under two grassland types along an altitudinal gradient: influence of temperature and solar radiation. Oecologia 114: 20-30.

Gilbert B., Wright S.J., Muller-Landau H.C., Kitajima K., Hernandéz A., 2006. Life history trade-offs in tropical trees and lianas. Ecology 87: 1281-1288.

Hairiah K., Sulistyani H., Suprayogo D., Widianto, Purnomosidhi P., Widodo R.H., Van Noordwijk M., 2006. Litter layer residence time in forest and coffee agroforestry systems in Sumberjaya, West Lampung. Forest Ecology and Management 224: 45-57.

Häring V., Köhler S., Gerold G., 2005. Ergebnisse der Bodenkartierung Toro, Nopu (Sulawesi, Indonesien) im Rahmen des SFB552 - Göttingen, 40 S.

Hendrick R.L., Pregitzer K.S., 1996. Temporal and depth-related patterns of fine root dynamics in northern hardwood forests. Journal of Ecology 84: 167-176.

Hertel D., Leuschner C., Hölscher D., 2003. Size and structure of fine root systems in oldgrowth and secondary tropical montane forests (Costa Rica). Biotropica 35: 143-153.

Hertel D., Leuschner Ch. 2006. Fine root mass and fine root production in tropical moist forests as dependent on soil, climate and elevation. In: Bruijnzeel, S., Juvik, J. (eds.) Mountains in the mist: Science for conserving and managing tropical montane cloud forests. Hawaii Univ. Press.

Hertel D., Leuschner Ch., Harteveld M., Wiens M., 2007. Fine root mass, distribution and regeneration in disturbed primary forests and secondary forests of the moist tropics. In: Tscharntke, T., Leuschner, Ch., Zeller, M. (eds.) The Stability of Tropical Rainforest Margins: Linking Ecological, Economic and Social Constraints. Springer, Berlin.

Huante P., Rincon E., Allen E.B., 1993. Effect of vesicular-arbuscular mycorrhizae on seedling growth of four tree species from the tropical deciduous forest in Mexico. Mycorrhiza 2: 141-145. 
Jackson R.B., Mooney H.A., Schulze E.D., 1997. A global budget for fine root biomass, surface area and nutrient contents. Ecology 94: 7362-7366.

Jandl R., Lindler M., Vestertal L., Bauwens B., Baritz R., Hagedorn F., Johnson D.W., Minkkinen K., Byrne K.A., 2006. How strongly can forest management influence soil carbon sequestration? Geoderma, doi:10.1016/j.geoderma.2006.09.003.

Janos D.P., 1980. Mycorrhizae influence tropical succession. Biotropica 12: 56-64.

King J.S., Albaugh T.J., Allen H.L., Buford M., Strain B.R., Dougherty P., 2002. Belowground carbon input to soil is controlled by nutrient availability and fine root dynamics in loblolly pine. New Phytologist 154: 389-398.

Kummerow J., Kummerow M., Souza da Silva W., 1982. Fine-root growth dynamics in cacao. Plant and soil 65: 201.

Lal R., 2005. Forest soils and carbon sequestration. Forest Ecology and Management 220: 242-258.

Leuschner C., Hertel D., Coners H., Buttner V., 2001. Root competition between beech and oak: a hypothesis. Oecologia 126: 276-284.

Leuschner C., Hertel D., Schmid I., Koch O., Muhs A., Hölscher D., 2004. Stand fine root biomass and fine root morphology in old-growth beech forests as a function of precipitation and soil fertility. Plant and soil 258: 43-56.

Leuschner C., Wiens M., Harteveld M.A., Hertel D., 2006. Patterns of fine root mass and distribution along a disturbance gradient in a tropical montane forest, Central Sulawesi. Plant and soil 283: 163-174.

Majdi H., Pregitzer K.S., Moren A.S., Nylund J.E., Agren G., 1996. Measuring fine root turnover in forest ecosystems. Plant and soil 276: 1-8.

Nadelhoffer K.J., Raich J.W., 1992. Fine root production estimates and belowground carbon allocation in forest ecosystems. Ecology 73: 1139-1147.

Nepstad D.C., Verissimo A., Alencar A., Nobre C., Lima E., Lefebvre P., Schlesinger P., Potter C., Moutinho P., Mendoza E., Cochrane M., Brooks V., 1999. Large-scale impoverishment of Amazonian forests by logging and fire. Nature 398: 505-508.

Nicotra A.B., Babicka N., Westoby M., 2002 Seedling root anatomy and morphology: an examination of ecological differentiation with rainfall using phylogenetically independent contrasts. Oecologia 130: 136-145.

Oelberman M., Voroney R.P., Kass D.C.L., Schlönvoigt A., 2006. Soil carbon and nitrogen dynamics using stable isotopes in 19- and 10-year-old tropical agroforestry systems. Geoderma 130: 356-367.

Ostonen I., Lõmhus K., Lasn R., 1999. The role of soil conditions in fine root ecomorphology in Norway spruce (Picea abies L. Karst.). Plant and soil 208: 283-292.

Persson H., 1978. Root dynamics in a young Scots pine stand in Central Sweden. Oikos 30: 508-519.

Persson H., 1980. Fine-root dynamics in a Scots pine stand with and without near optimum nutrient and water regimes. Acta Phytogeogr. Suecica 68: 101-110.

Powel S.W., Day F.P., 1991. Root production in four communities in the Great Dismal Swamp. American Journal of Botany 78: 288-297.

Powers J.S., 2004. Changes in soil carbon and nitrogen after contrasting land-use transitions in North-eastern Costa Rica. Ecosystems 7: 134-146.

Pregitzer K.S., Laskowski M., Burton A.J., Lessard C., Zak D., 1998. Variation in sugar maple root respiration with root diameter and soil depth. Tree Physiology 18: 665-670.

Pregitzer K.S., DeForest J.L., Burton A.J., Allen M.F., Ruess R.W., Hendrick R.L., 2002. Fine root architecture of nine North American trees. Ecological Monographs 72: 293-309. 
Raich J.W., 1983. Effects of forest conversion on the carbon budget of a tropical soil. Biotropica 15: 177-184.

Ruess R.W., Van Cleve K., Yarie J., Viereck L.A., 1996. Contribution of fine root production and turnover to the carbon and nitrogen cycling in taiga forest of the Alaskan interior. Canadian Journal of Forest Research. 26: 1326-1336.

Schroth G., Agra D' Angelo S., Geraldes Teixeira W., Haag D., Lieberei R., 2002. Conversion of secondary forest into agroforestry and monoculture plantations in Amazonia: consequences for biomass, litter and soil carbon stocks after 7 years. Forest Ecology and Management 163: 131-150.

Silver W.L., Vogt K.A., 1993. Fine root dynamics following single and multiple disturbances in a subtropical wet forest ecosystems. Journal of Ecology 81: 729-738.

Silver W.L., Thompson A.W., McGroddy M.E., Varner, R.K., Dias, J.D., Silva, H., Crill, P.M., Kellers, M., 2005. Fine root dynamics and trace gas fluxes in two lowland tropical forest soils. Global Change Biology 11: 290-360.

Sleigh P.A., Collin H.A., Hardwick K., 1984. Distribution of assimilate during the flush cycle of growth in Theobroma cacao L. Plant Growth Regulation 2: 381-391.

Smith K.C., de Assis Oliveira F., Gholz H.L., Baima A., 2002. Soil carbon stocks after forest conversion to tree plantations in lowland Amazonia, Brazil. Forest Ecology and Management 16: 257-263.

Sundarapandian S.M., Chandrasekaran S., Swamy P.S., 1996. Influence of disturbance on fine root biomass and productivity in two deciduous forests of Western Ghats Tamil Nadu. Current Science 70: 242-246.

Sundarapandian S.M., Chandrasekaran S., Swamy P.S. 1999. Variations in fine root biomass and net primary productivity due to conversion of tropical forests into plantations. Journal of Tropical Ecology 40, 305-312.

Tyree M.T., Velez V., Dalling J.W., 1998. Growth dynamics of root and shoot hydraulic conductance in seedlings of five Neotropical tree species: scaling to show possible adaptation to differing light regimes. Oecologia 114: 293-298.

Upadhaya K., Pandey H.N., Law P.S., Tripathi R.S., 2005. Dynamics of fine and coarse roots and nitrogen mineralization in a humid subtropical forest ecosystem of northeast India. Biology of Fertile Soils 41: 144-152.

Vogt K.A., Vogt D.J., Palmiotto P.A., Boon P., O'Hara J., Asbjornsen H., 1996. Review of root dynamics in forest ecosystems grouped by climate, climatic forest type and species. Plant and soil 187: 159-219.

Vogt K.A., Vogt D.J., Bloomfield J., 1998. Analysis of some direct and indirect methods fore estimating root biomass and production of forests at an ecosystem level. Plant and soil 200: 71-89.

Wahl S., Ryser P., 2000. Root tissue structure is linked to ecological strategies of grasses. New Phytologist 148: 459-471.

Wells C.E., Eissenstat D.M., 2001. Marked differences in survivorship among apple roots of different diameters. Ecology 82: 882-892. Espleta \& Donovan

Withington J.M., Reich P.B., Oleksyn J., Eissenstat D.M., 2006. Comparisons of structure and life span in roots and leaves among temperate trees. Ecological Monographs 76: 381-397.

Wilczynski C.J., Pickett S.T.A. 1993. Fine-root biomass within experimental canopy gaps evidence for a belowground gap. J. Veg. Sci. 4, 571-574.

Wright S.J., Muller-Landau H.C., Condit R., Hubbell S.P., 2003. Gap-dependent recruitment, realized vital rates, and size distribution of tropical trees. Ecology 84: 3174-3185.

Xiao C.W., Yuste J.C., Janssens I.A., Roskams P., Nachtergale L., Carrara A., Sanchez B.Y., Ceulemans R., 2003. Above- and belowground biomass and net primary production in a 73-year-old Scots pine forest. Tree Physiology 23: 505-516. 
Zangaro W., Nishidate F.R., Spago Camargo F.R., Gorete Romagnoli G., Vandressen J., 2005. Relationships among arbuscular mycorrhizas, root morphology and seedling growth of tropical native woody species in southern Brazil. Journal of Tropical Ecology 21: $529-540$ 


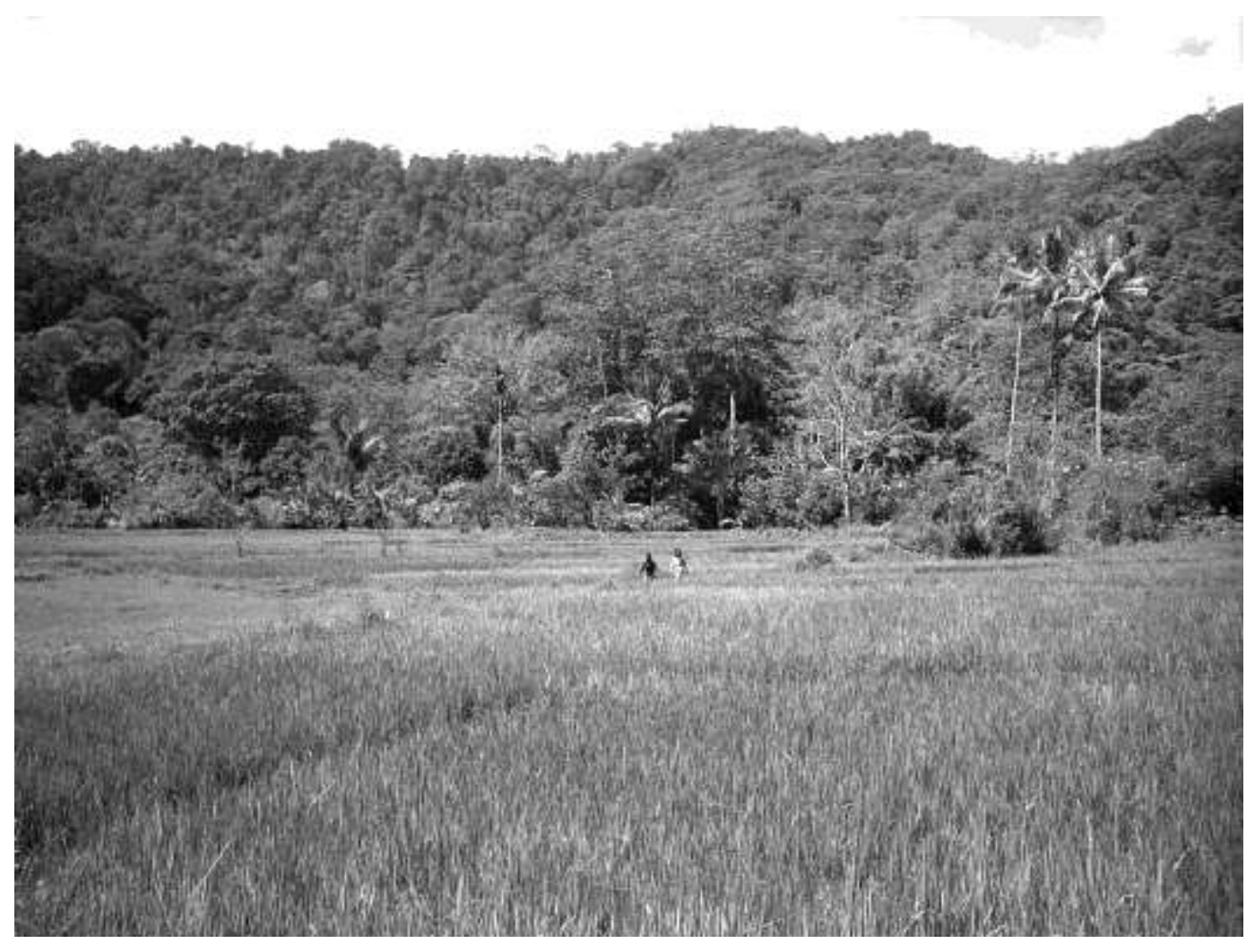


Chapter 6

\section{Synthesis}




\section{Introduction}

South-east Asia is suffering from the highest deforestation rates in the world (Achard et al. 2002) and the remaining forest areas are often being encroached at their margins by selective logging and the establishment of small-scale agroforestry systems. These disturbed old-growth tropical forests represent a woody vegetation type that is becoming increasingly important throughout the tropics (Lambin et al. 2003). In Indonesia many protected forest areas are characterized by an undisturbed core area and a gradient of increasing forest use intensity towards the edge (Collins et al. 1991). These changes in forest use towards the forest margin lead to a reduction in ecosystem carbon storage due to immediate removal of aboveground biomass and a subsequent reduction in belowground biomass and soil organic carbon (van Noordwijk et al. 1997). Tropical forests are often characterized by a rapid fine root turnover, consequently fine root dynamics can contribute significantly to ecosystem carbon fluxes (Silver et al. 2005). Despite its importance, carbon allocation to the root system remains one of the least well quantified $C$ fluxes in terrestrial ecosystems (Hendrick \& Pregitzer 1992; Davidson et al. 2002; Matamala et al. 2003). Little is known in particular about changes in fine root dynamics due to forest disturbance (Vogt et al. 1996; Hertel et al. 2007). The objective of this thesis is to make a detailed assessment of the impact of increasing forest use intensity on the fine root system of a moist tropical forest. I aimed at answering the following research questions:

- What effect does increasing forest use intensity have on fine root mass and its vertical distribution?

- How do changes in forest use intensity influence spatial and temporal variation in fine root abundance?

- What is the effect of forest disturbance on fine root turnover and the related carbon fluxes?

- Does change in forest use affect fine root morphological traits?

- Which parameters of forest structure, climate or soil chemistry are major determinants for possible differences in fine root mass, productivity or morphology along the disturbance gradient?

This study was conducted along a gradient in forest-use intensity in the margins of the Lore Lindu National Park in Central Sulawesi. The gradient was represented by 5 forest use types common in this region: undisturbed natural forest (type A), slightly-disturbed forests with selective extraction of small timber (type B), moderately-disturbed forests with selective extraction of large timber (type $C$ ), heavily disturbed cacao agroforestry systems under a cover of remaining old growth forest trees (type $D$ ) and cacao agroforestry systems under a cover of planted shading trees (type E). Each of the forest types was replicated three times. Due to time restrictions, however, the study on fine root productivity was conducted on one replica of each type only. 


\section{Fine root mass and distribution along the disturbance gradient}

Root inventory in the upper $50 \mathrm{~cm}$ of the soil showed a gradual decrease in fine root biomass (living mass) with increasing forest use intensity, with a more than $45 \%$ reduction between the undisturbed forest stands and the heavily disturbed agroforestry stands (chapter 2). Interestingly, even the selective logging of small diameter stems led to a significant decrease in standing fine root biomass. More surprisingly, fine root necromass showed a similar pattern and significantly decreased from the undisturbed forests to the heavily-disturbed forests as well (chapter 2).

Human-induced gap formation can affect the fine root system either through changes in soil moisture and temperature regimes, changes in input rates of organic matter or changes in the aboveground structure. In our study area, soil base saturation and $\mathrm{pH}$ did not vary distinctly with the level of forest use, and soil temperature showed only a minor increase due to forest disturbance. Consequently, we did not find a significant effect of soil chemical and climatological parameters on the standing fine root bio- and necromass in our study sites. The lack of influence of these soil parameters on the fine root system in our study area is further supported by the observation that the vertical distribution patterns did not differ markedly between the different forest use types. In all forest stands, fine root biomass exponentially decreased with root depth and about $90 \%$ of the total fine root mass was found in the upper $20 \mathrm{~cm}$ of the soil. Temperature, moisture and nutrient supply are known to be key factors controlling the depth distribution of fine roots in soils (Fitter 1996; Sainju and Good 1993).

On the other hand, the forest use types could clearly be differentiated by above ground structural parameters like canopy cover, dbh and total basal area of the stands. As our data showed a significant reduction in fine root biomass with moderate to high levels of timber extraction we expected total basal area of the stands to be one of the most important variables influencing fine root biomass. Nevertheless, according to PCA and correlation analyses the main determinant for the reduction in fine root biomass was a decrease in canopy cover. If canopy cover, but not stem density or basal area, would indeed be the most important variable influencing fine root biomass, canopy gaps with reduced leaf area would be expected to coincide with reduced fine root densities in the soil, according to the root gap theory of Wilczynski and Pickett (1993) which predicts a less closed 'root canopy' after disturbance of the leaf canopy. However, we found only a moderate spatial heterogeneity in standing fine root biomass, which just differed marginally between the differed forest use types (chapter 3). Moreover, we did not find any dependence of fine root biomass on the distance of the sampling location to the nearest tree. This lack of dependence of fine root biomass on tree distance has also been observed in other studies in temperate or tropical old-growth forests (Hertel 1999, Muñoz \& Beer 2001). We hypothesize that timber extraction 
and the associated canopy opening did not result in distinct root gaps, but rather caused an overall thinning of the root system leading to lowered stand totals of fine root biomass.

\section{Seasonal variation in fine root bio- and necromass}

In general, little variation over time in standing fine root biomass occurs in tropical moist forests lacking a distinct seasonal pattern in rainfall. Central Sulawesi has a weakly seasonal tropical climate with two periods of increased rainfall, in October-November and in MarchApril (Aldrian and Susanto, 2003).

The seasonal variation in fine root biomass as averaged over the 20 sampling locations was much larger in the natural forest and the stands with small or large timber extraction compared to that in the cacao agroforestry system (chapter 3 ). This difference is most likely caused by the fact that cacao trees grow in 2-3 flushes per year. Shoot flushing occurs when fine root growth activity is at its lowest level and vice versa (Kummerow et al. 1982). However, these flushes are largely independent of seasonal climate variation and therefore usually do not occur simultaneous in all cacao trees of a stand, thus smoothing out any seasonal variation. When considering each of the sampling locations separately the temporal variation of all forest types investigated was actually the highest in the cacao agroforestry system.

In general, seasonal maxima of FRB were observed from the end of May to the end of August 2004 and minima at the end of November 2004 (chapter 3). The fine root biomass maximum coincided with a three-month period of relatively little rainfall, while the minimum was observed at the end of a subsequent wetter period. It has frequently been reported that soil moisture can have a pronounced influence on fine root turnover and productivity. However, whether increase in soil moisture has a positive or a negative effect on fine root turnover seems to differ with species and location. Some studies reported a decrease of fine root turnover with increase in soil moisture (Pregitzer et al. 1993, Hendrick \& Pregitzer 1996), while others stated the opposite (Joslin et al. 2000, Jones et al. 2003).

The seasonal variation in fine root necromass was much less pronounced than seasonal variation in fine root biomass in all four forest use types. Surprisingly, we did not observe an increase in root necromass after root biomass had decreased from the dry to the wet season. Rapid changes in fine root biomass normally have profound effects on fine root necromass standing stocks. However, the small changes observed in our study might be explained by rapid decomposition processes in the hot and moist climate of Sulawesi.

\section{The impact of forest use on fine root dynamics}

There is much controversy about the most appropriate technique to quantify fine root productivity, and advantages and disadvantages of each method have been extensively discussed in the literature without reaching consensus (e.g. Lehmann \& Zech 1998; Mäkelä 
\& Vanninen 2000; Hertel \& Leuschner 2002; Hendricks et al. 2006). To obtain a reliable fine root production estimate we used three different methods in parallel: ingrowth cores, sequential coring in combination with the minimum/maximum calculation method (Persson 1978) and sequential coring in combination with the balancing transfer method (Fairley and Alexander 1985). Even though estimated values of fine root production in the upper $20 \mathrm{~cm}$ of the soil were slightly lower when using the ingrowth core method than the production values estimated with either of the sequential coring methods, the observed pattern was similar (chapter 4). Fine root production was significantly lower in the forest stands where small or large timber extraction occurred (type $B$ and $C$ ) than in the undisturbed forest stands (type A). However, in the agroforestry stands, fine root production was markedly higher compared to the heavily disturbed natural forest stands. The observed decrease in fine root production with increasing forest use in the sequence A-B-C was inherently connected to the decrease in standing fine root biomass and was therefore related to a reduction in total basal area, tree height, dbh and canopy cover of the stands as caused by timber extraction. A similar influence of stand structure on root productivity was reported in other studies (Sundarapandian et al. 1996, Drexhage \& Colin 2001, Le Goff \& Ottorini 2001, Jones et al. 2003). However, this contrasted with our findings that the cacao plantations (type D and E) had a lower mean tree height, lower total basal area and lower mean dbh compared to the selectively logged forests, while having a higher fine root production. Furthermore, despite a gradual decline in fine root biomass with increasing disturbance level in the three natural forest types, no significant differences in fine root production were observed between the stands with small timber extraction and those with large timber extraction. As fine root production per unit ground area is a function of fine root biomass and fine root growth rate, the relatively high fine root growth observed in the agroforestry stands and the heavily disturbed natural forest stands might, in this case, be related to a higher specific fine root growth rate. When looking at the rate of fine root growth in the upper $10 \mathrm{~cm}$ of the soil we indeed found a significantly higher growth rate in the cacao agroforestry sites and in the sites with large timber extraction (chapter 5). Fine root growth rate is in turn strongly influenced by fine root morphology. Both the trees in the heavily disturbed forest stands with relatively more fast-growing species as well as those in the agroforestry systems were found to have a larger SRA and root tip abundance compared to the trees in the undisturbed stands (chapter 5). Additionally, the roots in the cacao agroforestry systems showed significantly higher $\mathrm{N}$ concentrations compared to the other forest use types. Both high SRA values and high $\mathrm{N}$ concentrations are known to be positively correlated with fine root turnover (Eissenstat 1991, Comas et al. 2002, Espleta \& Donovan 2002, Whithington et al. 2006). We therefore conclude that the higher specific growth activity of fine roots in the moderately and heavily disturbed forest stands resulted from differences in fine root morphology and $\mathrm{N}$ content. In terms of carbon fluxes the higher root growth activity in these stands partly compensated for the decrease in fine root biomass with increasing disturbance. 


\section{Implications for soil carbon fluxes}

Converting natural forests to agricultural systems in the humid tropics generally leads to a reduction in ecosystem carbon storage due to immediate removal of aboveground biomass and a gradual subsequent reduction in soil organic carbon (SOC, van Noordwijk et al. 1997). The conversion from natural old growth forests to cacao agroforestry systems in our study area strongly reduced the carbon storage in standing above-ground biomass as well, mainly because of the removal of large trees. This reduction corresponded to a loss of about $600 \mathrm{t}$ $\mathrm{C} \mathrm{ha}^{-1}$ (Steffan-Dewenter et al. 2007). However, forest conversion to cacao agroforestry also significantly reduced the soil organic carbon stock. SOC in the upper $20 \mathrm{~cm}$ of the soil was on average about $40 \%$ lower in the plantation sites ( $D$ and $E$ ) compared to the three forest sites (A-C, Häring et al. 2005).

Carbon stored within an ecosystem is essentially the difference between carbon gained by photosynthesis and carbon lost by respiration of all components of the ecosystem. About half of the assimilated carbon in forests is eventually allocated and transferred below-ground via root growth and turnover, root exudates and litter deposition (Montagnini and Nair 2004). Inevitably, practices that influence root growth and turnover also have an impact on the soil $\mathrm{C}$ stock. In the previous paragraphs, the effects of increasing forest use intensity on standing fine root mass and productivity have been described. However, an important question remains: What does the observed impact of forest disturbance on the fine root system eventually mean for the fine-root-related carbon transfer to the soil carbon pool?

We found that the amount of carbon added annually to the soil by fine root mortality was significantly higher in the undisturbed and slightly disturbed forest stands (type $A$ and $B$ ) than in the moderately and heavily disturbed stands (type $C$ and D). Only in the plantation with planted shading trees (type E) the fine-root-related carbon flux to the soil once more reached a relatively high (intermediate) level despite a low standing fine root biomass (chapter 4). The observed differences in fine-root-related $C$ fluxes are most likely caused by a combination of factors: Firstly, a decrease in standing fine root biomass due to timber extraction can lead to a corresponding mass-based reduction in fine root production and mortality. Secondly, changes in species composition and the related root morphological differences can have a profound impact on fine root growth-rate and turnover (chapter 5). The annual carbon input to the soil with fine root mortality accounted for $2.2-4.6 \%$ of the total soil organic carbon stock.

Carbon input to the soil with leaf litter fall showed a slightly different pattern than C-input with fine root litter production: it gradually decreased along the disturbance gradient and did not show an increase with further intensification of forest use. In total, $\mathrm{C}$ flux to the soil through above- and below-ground litter fall decreased with increasing forest disturbance. The leaf litter exceeded fine root litter in the forest stands and in the agroforestry system under natural shading cover (type $\mathrm{D}$ ), but was comparable in the intensively managed agro-forest stand with planted shading trees (type E). Therefore, the relative importance of the below- 
ground litter production was larger in forest use type E compared to any of the other forest use types. This is important as different tree species apparently not only can have different carbon allocation strategies resulting in different rates of organic carbon input to the soil (Guo et al. 2005), but can also differ in respect to the pathway of carbon input. I conclude that forest conversion has a profound negative effect on the fine-root-related carbon sink strength, despite the fact that crop trees and planted shade trees could partly compensate for this effect through an over-proportionally high fine-root-related $\mathrm{C}$ input to the soil.

\section{References}

Achard F., Eva H.D., Stibig H.J. et al., 2002. Determination of deforestation rates of the world's humid tropical forests. Science 297: 999-1002.

Aldrian E., Susanto R., 2003. Identification of three dominant rainfall regions within Indonesia and their relationship to sea surface temperature. Int. J. Climatology 23: 1435-1452.

Collins N.M., Sayer J.A., Whitmore T.C., 1991. The Conservation Atlas of Tropical forests. Asia and the Pacific. Macmillan Press, London.

Comas L.H., Bouma T.J., Eissenstat D.M., 2002. Linking root traits to potential growth rate in six temperate tree species. Oecologia 132: 34-43.

Davidson E.A., Savage K., Bolstad P., Clark D.A., Curtis P.S., Ellsworth D.S., Hanson P.J., Law B.E., Luo Y., Pregitzer K.S., Randolph J.C., Zak D., 2002. Below-ground carbon allocation in forests estimated from litterfall and IRGA-based soil respiration measurements. Agricultural and Forest Meteorology 113: 39-51.

Drexhage M., Colin F., 2006. Estimating root system biomass from breast-height diameters. Forestry 74: 491-497.

Eissenstat D.M., 1991. On the relationship between specific root length and the rate of root proliferation: a field study using citrus rootstocks. New Phytologist 188: 63-68.

Espeleta J.F., Donovan L.A., 2002. Fine root demography and morphology in response to soil resources availability among xeric and mesic sandhill tree species. Functional Ecology 16: 113-121.

Fairley R.I., Alexander I.J., 1985. Methods of calculating fine root production in forests. In: Fitter, A.H., Atkinson, D. \& Read, D.J. (eds.) Ecological interactions in soil, plants, microbes and animals. Blackwell Science Publishers, Oxford, pp 37-42.

Fitter A., 1996. Characteristics and functions of root systems. In: Waisel Y., Eshel A., Kafkafi U. (eds.) Plant roots: the hidden half. Dekker, New York.

Hendrick R.L., Pregitzer K.S., 1992. The demography of fine roots in a northern hardwood forest. Ecology 73: 1094-1104.

Hendrick R.L., Pregitzer K.S., 1996. Temporal and depth-related patterns of fine root dynamics in northern hardwood forests. Journal of Ecology 84: 167-176.

Hendricks J.J., Hendrick R.L., Wilson C.A., Mitchell R.J., Pecot S.D., Guo D., 2006. Assessing the patterns and controls of fine root dynamics: an empirical test and methodological review. Journal of Ecology 94: 40-57.

Hertel D., 1999. Das Feinwurzelsystem von Rein- und Mischbeständen der Rotbuche: Struktur, Dynamik und interspezifische Konkurrenz. Dissertationes Botanicae 317.

Hertel D., Leuschner Ch., 2002. A comparison of four different fine root production estimates with ecosystem carbon balance data in a Fagus-Quercus mixed forest. Plant Soil 239, 237-251. 
Hertel D., Leuschner Ch., 2005. Fine root mass and fine root production in tropical moist forests as dependent on soil, climate and elevation. In Mountains in the mist: Science for conserving and managing tropical montane cloud forests. Eds. L.A. Bruijnzeel and J. Juvik. Hawaii Univ. Press. (in press).

Hertel D., Leuschner Ch., Harteveld M., Wiens M., 2007. Fine root mass, distribution and regeneration in disturbed primary forests and secondary forests of the moist tropics. In: Tscharntke, T., Leuschner, Ch., Zeller, M. (eds.) The Stability of Tropical Rainforest Margins: Linking Ecological, Economic and Social Constraints. Springer, Berlin.

Jones R.H., Mitchell R.J., Stevens G.N., Pecot S. D., 2003. Controls of fine root dynamics across a gradient of gap sizes in a pine woodland. Oecologia 134: 132-143.

Joslin J.D., Wolfe M.H., Hanson P.J., 2000. Effects of altered water regimes on forest root systems. New Phytologist 147: 117-129.

Kummerow J., Kummerow M., Souza da Silva W., 1982. Fine-root growth dynamics in cacao (Theobroma cacao). Plant Soil 65: 193-201.

Lambin E.F., Geist H.J., Lepers E., 2003. Dynamics of land-use and land-cover change in tropical regions. Annu.Rev.Environ.Resour. 28: 205-41

Le Goff N., Ottorini J.M., 2001. Root biomass and biomass increment in a beech (Fagus sylvatica) stand in North East France. Annals of Forest Science 58: 1-13.

Lehmann J., Zech W., 1998. Fine root turnover of irrigated hedgerow intercropping in Northern Kenya. Plant and Soil 198: 19-31.

Mäkelä A., Vanninen P., 2000. Estimation of fine root mortality and growth from simple measurements: a method based on system dynamics. Trees 14: 316-323.

Matamala R., Gonzalez-Meler M.A., Jastrow J.D., Norby R.J., Schlesinger W.H., 2003. Impacts of fine root turnover on forest NPP and soil $\mathrm{C}$ sequestration potential. Science 302: 1385-1387.

Muñoz F., Beer J., 2001. Fine root dynamics of shaded cacao plantations in Costa Rica. Agroforestry Systems 51: 119-130.

Persson H., 1978. Root dynamics in a young Scots pine stand in Central Sweden. Oikos 30, 508-519.

Pregitzer K.S., Hendrick R.L., Fogel R., 1993. The demography of fine roots in response to patches of water and nitrogen. New Phytologist 125: 575-580.

Sainju V.M. and Good R.E. 1993. Vertical root distribution in relation to soil properties in New Jersey pinelands forests. Plant Soil 150, 87-97.

Silver W.L., Thompson A.W., McGroddy M.E., Varner, R.K., Dias, J.D., Silva, H., Crill, P.M., Kellers, M., 2005. Fine root dynamics and trace gas fluxes in two lowland tropical forest soils. Global Change Biology 11: 290-360.

Sundarapandian S.M., Chandrasekaran S., Swamy P.S., 1996. Influence of disturbance on fine root biomass and productivity in two deciduous forests of Western Ghats Tamil Nadu. Current Science 70: 242-246.

van Noordwijk M., Cerri C., Woomer P.L., Nugroho K., Bernoux M., 1997. Soil carbon in the humid tropical forest zone. Geoderma 79: 187-225.

Vogt K.A., Vogt D.J., Palmiotto P.A., O'Hara J., Asbjornsen H. 1996. Review of root dynamics in forest ecosystems grouped by climate, climatic forest type and species. Plant Soil 198, 159-219.

Wilczynski C.J., Pickett S.T.A., 1993. Fine-root biomass within experimental canopy gaps evidence for a belowground gap. J. Veg. Sci. 4, 571-574.

Withington J.M., Reich P.B., Oleksyn J., Eissenstat D.M., 2006. Comparisons of structure and life span in roots and leaves among temperate trees. Ecological Monographs 76 : 381-397. 
Chapter 6 


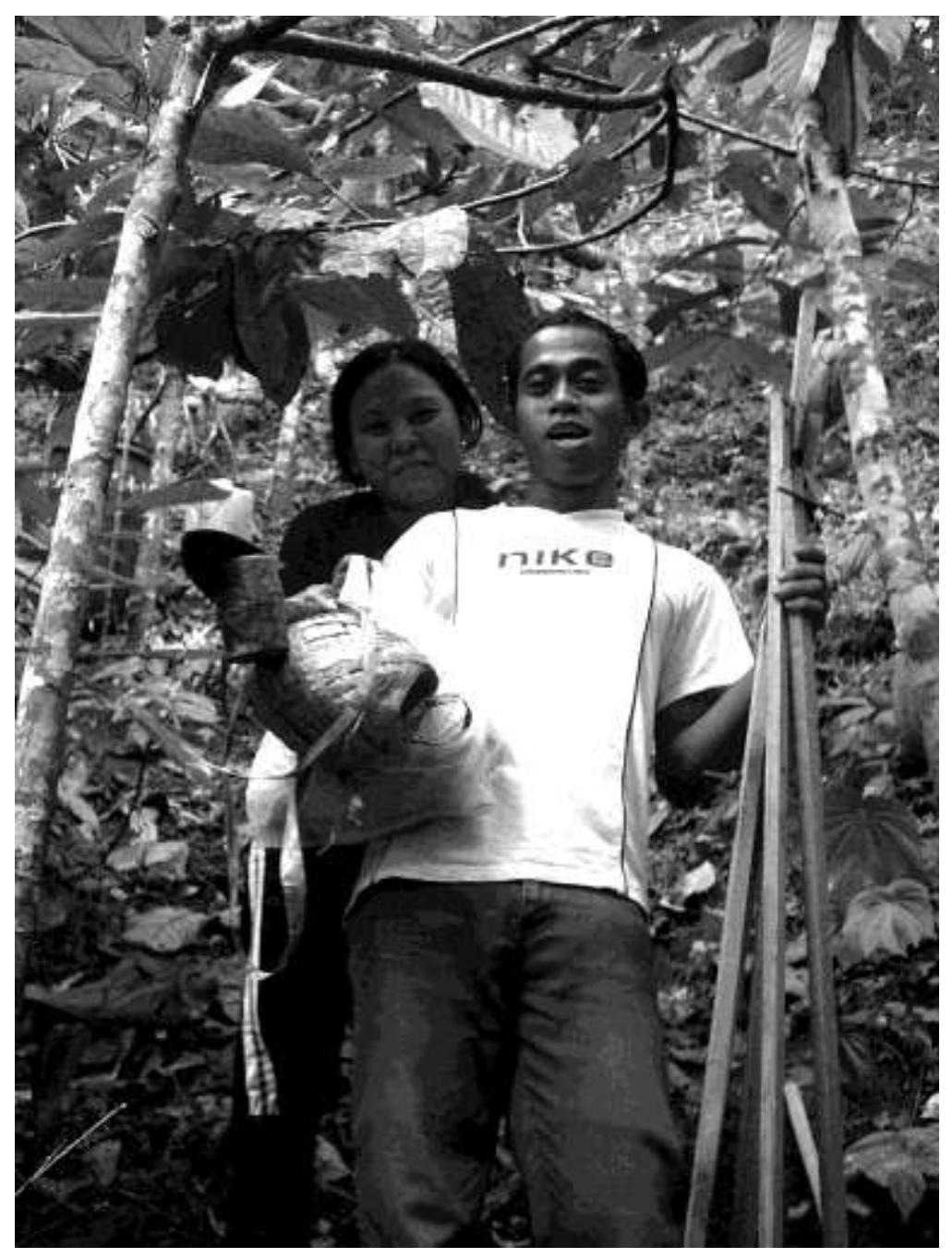




\section{Acknowledgements}

The three and a half years of doing my PhD-research and writing this thesis have been an interesting, challenging, and sometimes quite difficult journey, but I absolutely don't regret taking it! Living and working in a tropical country for a few years has always been a dream of mine and I am glad I got the chance to fulfil that dream. However, I would have never been able to finish this $\mathrm{PhD}$ without the help and support of so many wonderful people.

First of all I would like to thank Prof. Christoph Leuschner and Dr. Dietrich Hertel for creating and giving me the opportunity to do this research and for teaching me a great deal about (tropical) ecology, doing research and writing scientific articles. I am particularly grateful to Dietrich for the countless useful discussions, the many writing tips and his ongoing enthusiasm for my work. Further I would like to thank my colleagues from the Department of Plant Ecology for the very nice working atmosphere! Special thanks to: Dirk, Ina and Marina for the support, advice and many nice chats and to Astrid and Heinz for their help in two fields where I would have been lost on my own: German bureaucracy and computer installation.

Next I would like to thank all my colleagues from the STORMA project: it has been a pleasure sharing my Indonesia experience with such a nice group of people. Terima kasih banyak to Eda and Edi, my two assistants in Indonesia, for all their great help with the field and lab work and for being so enthusiastic, cheerful and open-minded! Many thanks also to Maria Wiens, who made an important contribution to this thesis with her MSc-project and who is one of the sweetest persons I know. Stefan and Yanti Köhler I would like to thank for the help in the lab and the pleasant and tasty dinners we shared. My time in Palu (and Göttingen) wouldn't have been the same without the friendship of Kerstin and Klaus: I very much enjoyed our talks, trips and karaoke nights!

Further I would like to thank my friends and family in the Netherlands for their interest, support and love: your visits, phone calls, e-mails and packages have meant a lot to me! I especially want to thank my parents for flying over to Indonesia when I was in the hospital, for lovingly nursing me back to health, and being supportive of my choice to stay there and finish my job.

Finally: Lars, you have been such an important part of my life during the last years and you have shared everything with me, from climbing the mountains in Toro to the last stressful weeks of writing: what can I say... thank you for being there for me all the way! 


\section{Curriculum vitae}

\section{Personal details}

Date of birth

12. September 1977

Place of birth

Amersfoort, The Netherlands

Nationality

Dutch

\section{Education}

2003 - 2007 PhD study at the Department of Plant Ecology,

Albrecht-von-Haller Institute for Plant Sciences,

University of Göttingen, Germany

1996 - 2002 Study of biology at the University of Groningen, the Netherlands

Degree obtained: M. Sc.

1989 - 1996 Christelijk Lyceum Veenendaal, the Netherlands

High School graduation: HAVO and VWO 
